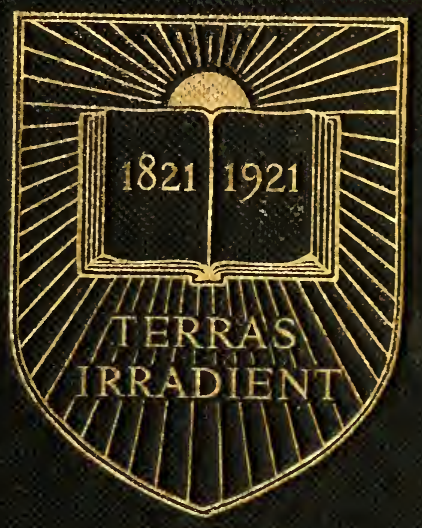




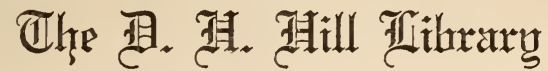

Zurth (Tarolina State Trallege

QH368

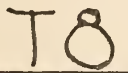






\section{The amberst 2Books}

\section{THE COMING OF MAN}





\title{
THE COMING OF MAN
}

\author{
BY \\ JOHN M. TYLER
}

PROFESSOR EMERITUS OF BIOLOGY

AMHERST COLLEGE

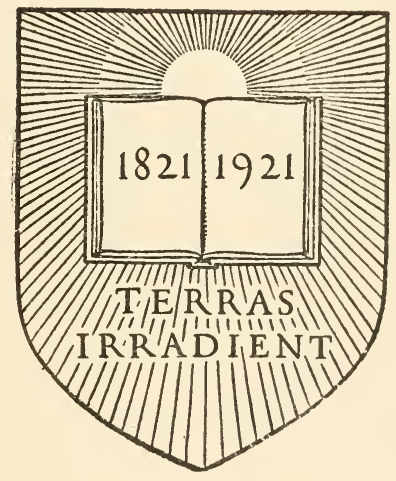

BOSTON

MARSHALL JONES COMPANY

I923 



\section{LIBRARY \\ N. C. State College}

\section{PREFACE}

T $\mathrm{T}$ seems needless to write a preface to a book which is merely and altogether an introduction, a small book on a great subject.

We are beginning to appreciate the importance of the story of man's slow and endless "coming." To select and chronicle a few of the most conspicuous successive stages of his ascent and to sketch their essential characteristics is far from easy. To discover the meaning of the changes and processes involved in his ascent is like searching for buried treasures. Condensed histories of the growth of the United States during a few centuries fill a dozen or more large volumes. We must attempt to compress the whole biological history of animal and human life into one booklet. The attempt seems absurd.

We will begin by enumerating the most prominent stages, the land marks, of human evolution, the rise of one function after another to preeminence in the animal body. We will not attempt to construct a genealogical tree of the animal kingdom; but only to note the appearance, advance or culmination of organs or powers which gave their possessors marked advantage and temporary or permanent success. We will try to introduce the reader to a few typical familiar forms, which appear to have been stranded near the highwater mark of the tide of life in some long-passed time, and thus make him acquainted with the leading characters or actors of their place and day. We cannot attempt to give a detailed description of the anatomy of these unconscious heroes of the great drama; but only to notice their deeds, efforts, struggles and achievements. At best our sketch can be only a rude outline devoid of all shading and of many important features: we hope that it is true substantially and not misleading. 
Having glanced at some of the chief actors we will look at the stage-setting, their surroundings and environment, their relations to the great world in which they were feeling their way. Was their situation, perhaps, not altogether unlike our own to-day? Can we draw any useful inferences from their successes or failures? Above all what constituted fitness to survive and progress, and can we derive from their experience any suggestions as to what are the elements or marks of fitness under present conditions? Do the unintelligent efforts and experiments of our "humble fellows" of times passed, give us a reasonable ground of hope in a brighter future? These are the vital, all-important questions.

The book is intended to be an introduction in a more literal sense. The references at the foot of many pages and the bibliography are intended to lead the reader to an acquaintance with a few of the thinkers and writers who have thrown light on special subjects. If he will follow these suggestions, he will be led far in excellent company into wide and fascinating fields of research and discovery.

Finally, the bock is written especially for those who have never found time or inclination to study our benighted ancestors and predecessors, and their magnificent and truly heroic achievements. Not able to talk, or suffering from the malady of thought, they "lost themselves" in their work. Certainly "they wrestled hard as we do now." If it can persuade a few thoughtful souls to wonder at the amoeba, to become interested in the highly significant hydra, to admire clams and worms, to marvel at the strange experiments of reptiles, and gain a fellow-feeling for the plodding primitive mammal, the sleek cat and "aspiring ape," it will not have been written in vain.

If I am not mistaken, no less a thinker than the keen, stern, powerful theologian Jonathan Edwards, a loving observer of the beauties of nature in his younger days, has told us that supreme virtue consists in love for being in general. 


\section{CONTENTS}

CHAPTER

Preface . . . . . . . . . . . . v v

I. The Coming of Life . . . . . . . . . . I I

BACTERIA. PROTOZOA AND THE CELL. AMOEBA. PLANTS AND ANIMALS. COELENTERATES, ORGANS AND TISSUES. WORMS. THE BUILDING OF A BODY. ANNELIDS. THE RISE OF MUSCLE AND SENSE-ORGANS.

II. The Coming of a Backbone

EXTERNAL PROTECTIVE SKELETON OF MOLLUSKS.

THE CLAM. SQUIDS. EXTERNAL LOCOMOTIVE SKELETON OF ARTHROPODS. INSECTS. SMALL SIZE. METAMORPHOSIS. VERTEBRATES AND THE INTERNAL LOCOMOTIVE SKELETON. BONE, MUSCLE AND BRAIN. SHARKS AND GANOIDS.

III. The Rise of Land Life . . . . . . . . . .

GANOIDS AND LIFE IN FRESH WATER. EMERGENCE

ON LAND. AMPHIBIA. RISE OF TEMPERATURE.

DECREASE IN NUMBER OF EGGS. CARE OF YOUNG.

REPTILES, BULK AND POWER. BIRDS AND SWIFTNESS. MAMMALS AND SUCKLING OF YOUNG. PRIMATES AND ARBOREAL LIFE. HAND AND BRAIN.

IV. The Coming of Savage Man . . . . .

CLIMATIC CHANGES AND FORCED MIGRATIONS. DESCENT FROM THE TREES. APE-MAN. THE IRANIAN PLATEAU AND ROUTES OF EMIGRATION. NORTHERN EUROPE DURING THE GLACIAL PERIOD. FAMILY AND SOCIAL LIFE. BURIAL OF DEAD. WONDER AND THOUGHT. THE CRO-MAGNON RACE.

V. The Dawn of Civilization ......... INDUSTRIES. DOLMENS. RISE OF AGRICULTURE. TAMING OF THE SAVAGE. TRIBAL LIFE AND TRIBAL CONSCIENCE. SOCIAL LIFE, FOLKWAYS AND MORALS. PRIMITIVE RELIGION. CULTS AND MYSTERIES. THE GODDESS.

VI. The Rise of Personality

TRADE, COMMERCE, MIGRATIONS. THE COMING OF THE ARYANS. THE ACHAEANS. CULTS AND THEORIES. DIVERSITY OF GIFTS AND TENDENCIES. DIVERGENCE. THE RISE OF THE HERO. PERSONALITY AND LOYALTY. 
VII. The Logic of Evolution .. . . . . . . . . .

CELLS, TISSUES, AND ORGANS. ERA OF DIGESTION AND REPRODUCTION. RISE OF THE MUSCULAR SYSTEM. THE LOCOMOTIVE SKELETON. LOCOMOTION, SENSE-ORGANS AND BRAIN. CARE OF YOUNG. EDUCABILITY. WEAKNESS AND WITS. MAN, MORALS AND RELIGION. SUCCESSIVE DYNASTIES IN EVOLUTION. REVOLUTIONS AND OUTBREAKS. REVERSAL OF LOGICAL SEQUENCE AND DEGENERATION. A LIBERAL HUMAN EDUCATION.

VIII. NATURE AND MAN . . . . . . . . . . . . . . . SEAT OF CONTROL IN THE BODY. DIRECTIVITY. NEO-DARWINIANS AND NEO-LAMARCKIANS. NATURE AS FINAL ARBITER. OUR ABUSE AND EXPLOITATIONS OF NATURE. IS NATURE MORAL, IMMORAL OR UNMORAL? DANGERS OF COMPLEXITY. ASYMMETRY. CRIPPLES AND "REVERSED CRIPPLES."

IX. Man and EnVironment . . . . . . . . . . ADAPTATION. SURROUNDINGS. ENVIRONMENT. IMPORTANCE OF RELATIONS. EVOLUTION OF DISCOVERY. NEEDS. ARTIFICIAL ENVIRONMENT.

X. The Survival of the Fittest .........

CRITERIA OF FITNESS. VERTEBRATES VS. MOLLUSKS. AMPHIBIA VS. SHARKS. MAMMALS VS. REPTILES. PRIMATES AND APE-MAN VS. CARNIVORA. DOMINANCE AND FITNESS. SOCRATES AND CALLICLES. LIFE AND DISTANT ENDS. NATURE VS. DOMINANCE. ADVENTURE.

XI. Perfect Health

THE TYRANNY OF THE WEAKEST PART, - AND OF THE STRONGEST PART. SYMMETRY AND HEALTH. A HEALTHY NERVOUS SYSTEM. HEALTHY-MINDEDNESS. INTERESTS. VALUES. NATURAL DEVELOPMENT OF THE CHILD. VALUE OF PLAY INSTINCTS. ADOLESCENCE. NATURE AND DEVELOPMENT OF YOUTH. THE ADULT. DANGER OF SPECIALIZATION AND OVER-ADAPTATION. YOUNG OLD MEN. CONTAGION OF HEALTH.

Bibliography . . . . . . . . . I36

INDEX. . . . . . . . . . . . . I45 
THE COMING OF MAN 



\section{THE COMING OF MAN}

THE COMING OF LIFE

T was very long ago, far longer than we can possibly conceive. The everlasting hills were not yet born, the continents hardly sketched. We may stimulate our imagination to attempt the task by putting it in a somewhat different form.

Let us take a measuring rod a little more than eight feet long; let every inch correspond roughly to 100,000 years. The uppermost tenth of an inch representing 10,000 years would cover the whole historical period, the epochs of the discovery of metals, and overlap the New Stone Age. One inch carries us far back in Palæolithic time. Osborn places the appearance of pithecanthropus, the ape-man, at about 500,000 B. C., five inches from the top of our scale. ${ }^{1}$ The beginning of the Cenozoic period, or Age of Mammals, the last and shortest of the great geological periods, some 3,000,000 years, carries us down two and one-half feet. The Mesozoic period, the Age of Reptiles, occupying 9,000,000 years, would require ninety inches and cover nearly the whole of our rod, on which all human history occupied a part of one-tenth of an inch. The Palæozoic period was, perhaps, twice as long as the Mesozoic, about 18,000,000 years.

This is Schuchert's reckoning, giving a total of some

$124: 4 \mathrm{I}$. (2t=Number in Bibliography: $4 \mathrm{I}=$ Page of Book.) H. 85 . 
$30,000,000$ years to geologic time. The amount was considered by him very conservative, and by most geologists as quite inadequate. $^{2}$ It is a minimum. The weight of evidence seems to favor a length of from $90,000,000$ to $120,000,000$ years; some would make it much greater.

Into this ancient world life stole very quietly and without observation. Our most primitive forms of life, and they have already advanced far, are the bacteria. ${ }^{3}$ They are exceedingly minute, thousands together would not cover the comma on a page of print. They seem to be composed of a substance which we may call protoplasm. Many are too small to be visible under the highest powers of our microscopes; and we still know comparatively little of the finer structure of even the higher and larger forms.

They show great variety in size, form and structure. Usually they resemble spheres or short rods; some approach the lowest unicellular animals, the protozoa; others are scarcely distinguishable from the lowest plants, the protophyta. They form a group showing great variety, are exceedingly generalized, and the persistent survival or development of such a host of forms is the highest testimonial to the dour vitality of the stock.

Wherever life is possible there we find bacteria, in the sea, in hot springs, in the frozen north, on mountain-rocks, almost everywhere in the uppermost four or five feet of the soil, in the bodies of plants and animals. They fit into every crack and cranny in the world. Some flourish in light and air, to others these are harmful or destructive. They ask very little from nature, take whatever she offers and thrive. ${ }^{4}$

They are admirably adapted to live in an inorganic world or on dead material. Plants and animals die. Under the influence of the bacteria the proteins of their bodies are changed over into ammonia, and finally into nitrates, fit food for plants; other compounds are similarly handled. They

\footnotetext{
2 H. 85 .

3 2: 26. I IO.

4 G. 80 .
} 
form the essential link in the round of organized material stored up by the plant; eaten, used, and cast out by the animal; and changed again into plant food by these microscopic chemists. But they are not limited to this kind of foodmaterial.

One of the greatest triumphs of modern science is the fixation, combination and utilization of atmospheric nitrogen, a stubborn inert material which refuses, or is very slow, to combine with other elements. The bacteria solved this problem millions of years ago; in root-tubercles, and in the soil they are carrying on the same work to-day bare-handed, not in great laboratories. It is probable that carbon, either in the form of coal or charcoal, may be oxidized by certain of the soil bacteria. Carbon, at any ordinary temperature, seems even more inert than nitrogen. They are said to be able to oxidize paraffine and other resistant compounds. All this marvellous work of chemical analysis and synthesis goes on in or around the bodies of minute bacteria whose only reagents are such as the protoplasm can manufacture in and for itself. Every one is a marvellous synthetic laboratory, building up more complex compounds out of simpler ones, the work which modern chemists find most fascinating and difficult.

Their chief reagents in this synthetic work are the enzymes which are capable of bringing about changes in various substances without becoming a part of the final product. They seem to produce combinations without remaining in them; hence are not used up, but theoretically may be used indefinitely. A small amount of enzyme can do a large amount of work and synthesize a great amount of material. They are strange complex substances about which we still know very little; but the bacteria produce them in great variety and use them for many purposes.

Says Osborn: "In their power of finding energy or food in a lifeless world, the bacteria known as prototrophic, or 'primitive feeders,' are not only the simplest known organisms but it is probable that they represent the survival of a primordial 
stage of life chemistry. These bacteria derive both their energy and their nutrition directly from inorganic chemical compounds; such types were thus capable of living and flourishing in the lifeless earth before the advent of continuous sunshine and long before the first chlorophyllic stage (algæ) of the evolution of plant-life." They are anything but structureless, but we still know very little concerning their structure. They are far from homogeneous. We find granules of different shapes, sizes, and behavior toward stains; networks and strands of various character. Vacuoles play an important part. We will return to this subject in our glance at protozoa.

The bacteria may have remained for ages the highest forms of life. They cover a wide range of structure, complexity and development. They laid the first and lowest yet discovered tiers in the foundations of life. They still form an essential link in its maintenance. They have done their part well and thoroughly. Nature could afford to spend millions of years in their development. From them lines of inconceivable possibilities radiate.

The Protozoa. Here again we find great variety, a host of forms showing a long development, great adaptability and wide distribution. We select for our example the amœba, an exceedingly common form which has attracted and held the interest of all observers since its. first discovery. Though far larger than the average bacterium, the amœba is still minute - from $1 / 200$ to $1 / 500$ of an inch in diameter. It is a single cell, consisting of nucleus and cytoplasm, two quite distinct portions developed and differentiated out of the protoplasm of some ancient and far simpler and primitive bacterium. The nucleus is a small body, staining deeply and showing the presence of a very peculiar substance, chromatin. This substance is apparently present in many bacteria in small granules, "a diffused nucleus"; in others it seems to be almost equally, distributed through the protoplasm.

The cytoplasm of the amœba is a translucent, granular 
semifluid substance about as viscid as mucilage or cold molasses. It is not surrounded by any rigid cell-membrare and can put out rootlike or rounded projections, pseudopodia. It can withdraw these or can "flow" into one of them and thus move. The secret of this power of contractility, how a little mass of semifluid substance can continually change the tension of different portions and "squeeze" itself into new forms, is still an exceedingly difficult question.

It distinguishes its food before it comes in contact with it and hence seems to possess the sense of smell. It possesses a power which we must call consciousness. It responds to a variety of stimuli, in certain situations it seems to experiment by a sort of "trial and error " and to "feel its way."

The engulfed particle of food, alga or bacterium, is surrounded by a droplet or vacuole of acid fluid and is dissolved, digested; whatever is insoluble goes to the surface and is discharged. The dissolved nutriment is either burned up to furnish energy or stored up in granules, "oil-globules," or other forms; some of it passes into the nucleus and is here changed to cytoplasm or nuclear substance; here, and also in the cytoplasm, "dead matter" is changed into living substance, the constantly recurring miracle of life. The products of combustion and the waste substances of the body are discharged or excreted at the surface of the cell. Here also oxygen is absorbed, and respiration takes place. The amœba is a vortex or whirlpool on the face of nature continually taking in, building up materials, using them in a great variety of ways, oxidizing or disintegrating them again and casting them out. But it is a very enduring permanent whirlpool outlasting the everlasting hills.

The amœba grows. When it has reached a certain size, it divides into two new and young amœbr, and there is no old amœba left to die. It seems to elude and outwit death and to be potentially immortal, especially if the nucleus is rejuvenated - as is usually the case among the protozoa by an act of fusion or conjugation of two individuals, the promise of sex. 
We wondered at the synthetic and analytic processes going on in the bacteria. The amœba can depend on the bacteria and algæ for a rich and constant supply of highly organized food, a storehouse of potential energy. They relieve it of a certain amount and kind of work. But the chemistry of the amœba is anything but simple. It builds a great variety of substances; net-works, fluid vacuoles, granules, threads and masses of the most diverse materials. It requires a long list of reagents which it manufactures for itself, it uses these to make an array of substances which it distributes or combines for a great variety of purposes. What guides, combines all these forces and processes into the life of one individual feeling and acting amœba? We have no idea. That is one of the secrets of life.

The greatest asset of both bacterium and amœba is their small size. If of two spheres, one has twice the diameter of the other, the larger one will have eight times the mass, but only four times the surface. If they have the same internal structure, the same will be true of every granule and vacuole. Mass measures expenses for combustion, etc.; external surface measures the amount of oxygen absorbed, and of carbonic acid and excrete fluids discharged. The inner surface of vacuoles increases the amount of digestive and other fluids secreted, though perhaps somewhat less exactly. Hence the possible intake or income of the animal is measured by its surfaces, the expense by the mass to be maintained.

All the complexity of the structure of our internal organs, especially of our digestive, excretory and respiratory systems, represent an attempt, so to speak, to increase to the utmost the organic surface with the smallest increase of size and waste. Increase in size and bulk of any animal is a costly and dangerous experiment. The microscopic size of protozoa, and the ultra-minuteness of the bacteria, means relatively large incomes and small expenses. There is a relatively large or enormous balance to devote to reproduction. Hence the enormously rapid reproduction and increase of these forms. 


\section{THE COMING OF LIFE}

We must never think of the amœba as a simple, homogeneous body of uniform substance. It is quite the reverse of this in its granules of nutriment in the most diverse grades of assimilation; in its "formed materials," and its reagents; in its structural arrangements and "cell-organs." It is a whole chemical and physical laboratory whose work we have only begun to understand and appreciate. It is a hive of varied industries. In some respects it is far more wonderful than the body of higher animals, where all this work is distributed and writ large. Its wondrous adaptability enables it to occupy and possess every chink and corner of the world and to meet every emergency. We cannot but feel that such beings have come to stay, that they will surely succeed in the struggle for survival, and existence. They can hold their own.

We find among the higher protozoa, especially among the flagellata, groups or colonies of cells; some fixed, some rolling or whirling through the water. Usually the cells are all practically alike; but in volvox certain of them are entirely devoted to reproduction. The protozoa are forth-putting, building something more than single, solitary cells. This looks promising, as if something quite different, larger and possibly higher might come out of it.

We find consciousness in the amoba. Huxley once said that the appearance of consciousness, as the result of the irritation of brain particles, is as inexplicable as the appearance of the djin when Aladdin rubbed his lamp in the story. And it looks as if the consciousness of the amoba might be more like the djin which the fisherman saw slowly emerge from the jar which he had drawn from the sea. It may expand. But in this part of our first chapter our whole living world contains only bacteria, protozoa and algæ. All we dare say is that this looks decidedly new, and as if there might be something in it.

Protoplasm is certainly "a quite peculiar juice." It looks as if it might be a bundle of unrealized possibilities. Says Bergson: "The resistance of inert matter was the obstacle that had first to be overcome. Life seems to have succeeded 
in this by dint of humility, by making itself very small and very insinuating, bending to chemical and physical forces, consenting even to go a part of the way with them, like the switch that adopts for a while the direction of the rail it is endeavoring to leave. Of phenomena in the simplest forms of life, it is hard to say whether they are still physical and chemical or whether they are already vital. Life had to enter thus into the habits of inert matter, in order to draw it little by little, magnetized, as it were, to another track. The animate forms that first appeared were therefore of extreme simplicity. They were probably tiny masses of scarcely differentiated protoplasm, outwardly resembling the amœba observable today, but possessed of the tremendous internal push that was to raise them even to the highest forms of life. . . . It succeeded in inducing an increasing number of elements, ready to divide, to remain united. By the division of labor it knotted between them an indissoluble bond.... Life is tendency, and the essence of a tendency is to develop in the form of a sheaf creating, by its very growth, divergent directions among which its impetus is divided. This we observe in ourselves, in the evolution of that special tendency which we call our character."

Life is always sending its children out into the world to seek a kingdom; to be fruitful and multiply and fill and possess the earth. It is still sending out its groups of bacteria, of weeds, of insect pests, - usually small forms of intense vitality, of great adaptability, if not already adapted, to a wide range of climate and other conditions. Civilization often gives them new opportunities and they seize upon and make the most of them, and threaten to overwhelm us.

The first or a very early great divergence, or setting out of these pioneer adventurers, resulted in the establishment of the two great organic kingdoms, plants and animals. We have only lately begun to notice the experiments of bacteria and similar forms in producing coloring matters, pigments, of various hues and chemical structure. Coloring matters may have played a larger rôle in life and development than we 
have yet suspected, for these ancient experimenters were great utilizers of what at our first glance seems to us as mere byproducts, as they probably once were. Their present use and value in the life of the organism is still but slightly understood.

One of these substances is chlorophyl, the green matter in the leaves of plants by means of which they utilize the energy of the light in the sun's rays to break up carbon dioxide and build up starch. This is only one step in the process by which the plant stores up food and potential energy and passes it over to the animal.

Chlorophyl is one of the most conspicuous characteristics of plant life, but probably not the most fundamental. We have noticed that the bacteria are surrounded by a cell-wall or membrane. They cannot, like the amœba, engulf solid particles, but live on fluid materials absorbed from the surrounding water. They do not need to go in search of their nourishment, nor to recognize it when absorbed. They can remain stationary, or float.

In higher plants living on the land the water and dissolved substances are gained by a subterranean root-system. The chlorophyl is in the leaves exposing a very large amount of surface to the light and air. Root and leaf surfaces are connected by a stout elastic wooden trunk through which currents of sap flow upward and downward. The plant wastes no energy in locomotion, its expenses are very small, its income is steady and large; it has a large surplus balance to expend in growth and reproduction. A highly successful plant, like one of our weeds, can grow rapidly in comparatively dry and poor soil, seeds abundantly, tolerates changes of climatic and other conditions, and flourishes where our more delicate plants would die.

The cell-wall of cellulose, the fluid nourishment, the presence of chlorophyl are the chief characteristics of plants; yet no one of these is peculiar to them; the ability to use $\mathrm{CO}_{2}$ and salts as building material for starch and protein is certainly peculiar to them, however; every one can be found in some animals. But in plants they are all combined in one highly 
successful organism, characterized by tendencies even more than by details of structure.

We left our protozoa as little groups or colonies of cells, all alike except that in a few cases, as in volvox, certain cells have been set apart for reproduction. That much can be realized at a not much higher stage is proved by the very interesting group of sponges, at which we cannot afford to cast even a glance. We pick up our thread of development with the cœlenterates. These include our common sea-anemones and their near relations, the coral animals, which have contributed so much to the upbuilding and extension of coast and mainland; also the jelly-fishes. The group shows considerable variety of structure and attainment. Most of them are sessile polyps; the jelly-fishes are usually floating rather than actively swimming forms. The general plan of the group is well shown in our common fresh water hydra, which has preserved many primitive characters.

The green hydra is a small vase-shaped or tubular animal about a quarter of an inch in length; the brown hydra may be twice as large. It differs from the rest of the hydroid polyps in not being permanently attached but moving over the stone or stick, or swimming or floating in the water from place to place. This exceptional habit seems primitive. In its structure it reminds us of a lady's shopping-bag, covered with silk and lined with velvet. The opening into the bag corresponds to the mouth of hydra, the cavity is for digestion, the silk and velvet materials to two layers of cells enclosing the digestive cavity or archenteron. The mouth is surrounded by a ring of tentacles armed with nettle-cells for stinging and paralyzing its prey. During the breeding season we find on the outside of the animal a little swelling, a reproductive organ producing eggs or spermatozoa.

The fundamental structural characteristics of hydra, and of all cœlenterates, are a body composed of two layers of cells, ectoderm and entoderm, surrounding a primordial digestive cavity, the archenteron, which in jelly-fishes sends out 
tubes or branches to carry the more or less dissolved nutriment to all parts of the body. Respiration and excretion are maintained through the exposed surfaces of the cell-layers.

The protozoa showed us what could be accomplished by the single cell. Then cell-colonies appeared; and in volvox cells set apart purely for reproduction, the first need and function is to have cells devoted entirely and solely to its performance. It insured the survival of the species, as digestion maintained the survival of the individual. These are the two absolutely essential functions and therefore the first to be provided with special organs. The cœlenterates show us a stage where these two organs have attained their simplest and most primitive forms and structure. We might say that the plant almost attained but never outgrew this stage. There is a good suggestion in the name given by the older naturalists to this stage of animal life, zoöphytes or plant-animals.

These are not the only contributions which the cœlenterates made to the building of the body of higher animals. They developed quite a variety of tissues, groups of cells whose form and structure are adapted to the performance of a special function, but these cell-groups are not yet arranged and united in an organ having a special shape. An organ usually consists of several tissues; so a coat, corresponding to an organ, is made of several materials, cloth, thread, etc., arranged in a shape fitted to the wearer.

In the cœlenterates we find muscular and nervous tissues, generally in a rudimentary form. It begins to look as if these might some day take shape in exceedingly interesting organs. We find sensory cells each with its fine hair responding to delicate vibrations in the water or exposing a very large surface to chemical stimuli of various kinds. They are the promise of organs of hearing, smell, and taste. Little patches of pigment are sensitive to light and feel it, in a crude way, the direction of its source. They continually stimulate the cells of the growing and developing nervous tissue. Even in hydra this has formed a plexus beneath the skin, a sort of 
cobweb of cells and fibers enveloping the body. This is a well-formed and slightly organized and molded tissue, we might almost call it an. organ.

We may safely say that the protozoa have developed cells, the units of structure whose combination made possible the rise of higher forms. The cœlenterates have developed these cells farther, have differentiated them by division of labor; have builded the two absolutely essential organs, and have furnished some most important tissues whose grouping, combination, arrangement and shaping will make the efficient organs of higher types.

Here again as in bacteria and protozoa we find a small amount of realization and attainment, and a great bundle of vast but vague possibilities; their vagueness is a symptom of the far higher new achievements which they were to attain. They paved the way to greater and swifter, or at least less wearisomely slow, advance. Or one might say that they laid deep and solid foundations, and gathered an abundance of material, so that their descendants might erect a fortresspalace of strength and beauty. Despise not the day of small things, greater things will come in time; and our wealth of time is inexhaustible.

Worms. A wise old German professor used to say with whimsical exaggeration: "Study worms. If you know them thoroughly, you will understand the whole animal kingdom. If you do not study them carefully, you will never know anything about zoölogy." He was right. In worms the possibilities of lower animal life begin to emerge from vagueness, to unfold and take form. We used to say: "All things are possible with God and in Austria"; we might add "and among worms." Still they belong to the great apostolic succession of layers of foundations. Most of their forms are buried beyond hope of recovery.

They do not form a well-marked type, kingdom or group; they are an assemblage of relics of a lost past. The study of the group is like looking into our grandmother's china closet 
or exploring the attic of an old house. We see only samples or fragments of departed greatness, of which most has long since been destroyed. Our systematic zoölogists left among worms all forms for which they could find no place elsewhere. These relics and nondescripts became isolated through the extinction of long series of connecting links. Many have strayed far and show few traces of their original home and ancestry. Others have been deformed by parasitism, the last refuge of weak and defeated animals.

But there is a deeper reason for their vast range of variation and adaptation. Give to a number of isolated savages who have never seen a hut all the materials for a house; and let every man build uncontrolled, as he will. Every one builds busily. The results are marvellous in their variety and eccentricity. Most of the buildings fall almost immediately in hopeless ruin. A few erect rudiments of a decent shelter. Or you may compare the period when the worms formed the vanguard and pioneers of animal development to the period of the Judges in Hebrew history: when "there was no king in Israel, but every man did that which was right in his own eyes."

The worms had inherited two layers of cells and two organs and a sacklike body. The wall of this body corresponded practically to a bit of skin covering a piece of the lining of the intestine. All structures between these two layers of our body were yet to come. They had the tissues out of which the other organs were to be builded. Their problem and task was to frame the other organs, and then combine them in one tough, strong mobile body adapted to all the conditions of life. In this experiment there were no hereditary achievements to guide them. The world of life must have been a marvellous sight during the era of the earliest worms. Most of the earliest experiments must have failed and disappeared quickly.

Traces of an early stage of vermian development have persisted in the flat worms or platyhelminthes, especially in the turbellaria, small worms oval or elliptical in outline; 
markedly depressed, that is flattened in a dorso-ventral direction. We might, perhaps, venture to imagine that some very primitive colenterate ancestor, akin to a jelly-fish (or a ctenophore) swam or crawled at the sea-bottom and moved by the musclar tissue, orginally fibers growing out of and between the cells of the two layers of the body. This muscular tissue increased and formed a thick mass and in time layers whose fibers run in all directions through the body. These muscles serve two main and distinct purposes. The inner layers are attached to and control the digestive sack. The outer layers are used for the locomotion of the body. These two sets of layers are used independently and become more and more distinct. The space between the two is occupied by a spongy mass of parenchym, perhaps orginally musclar, perhaps connectile.

In this spongy mass the tubular reproductive organs spread and branch. Here they are safely protected. In our modern flat worms they are exceedingly highly developed and very complex; more so than in any later or higher animal. The thickened skin or integument makes more and more difficult the discharge of the steadily increasing nitrogenous waste products of combustion in the muscles and elsewhere. Hence we find two tubes, often with many branches, serving as excretory organs. There is as yet no circulatory system, for the fluid in the spongy mass of parenchym allows of easy diffusion of nutriment and axygen to all parts of the body and of waste products from them to the excretory tubes, especially in a small animal. The exchange of carbon-dioxide for oxygen can still take place through the skin; there are no special gills.

The mouth is sometimes in the middle of the under surface of the body, sometimes near the front end. Over the nouth or œsophagus is a nerve-center or ganglion and from this, chords containing cells and fibers extend backward. The sense-organs consist of sensory hairs distributed over the body and clustered in sacklike depressions, otolith vesicles. We find pigment eyes, of various stages of development in different 
species, distributed around the front margin of the body or limited to the front end. The central position of the mouth and the distribution of the eyes, as well as the shape of the body, in certain forms seems to point backward toward some sort of radiate ancestor, though the general structure is bilateral, like that of our own bodies. But these insignificant worms seem to represent a stage where important structural changes and progress were taking place.

We have only glanced at flat worms as representing in some respects a very primitive vermian stage. We must neglect all the intermediate stages between them and the highest worms, as well as the large number of divergent and aberrant forms. We will not even attempt to condense into a few pages of brief, incomplete and inadequate outline the history of the most important changes in the building of the animal body, whose accomplishment must have required millions of years. Our sketch reduces itself to a couple of glimpses, not at all to a moving picture, of animal evolution.

We pass at a leap to the very highest worms, the annelids, of which the earth worm is a fair example, though the characteristics of the group are brought out far more clearly and adequately in the "clam-worms" of the marine mud-flats. Here we shall find the somewhat feeble and crude attempts of the flat worms realized in a definite practical and efficient form and structure.

The body of the annelid is segmented, composed of a longitudinal series of rings allowing great flexibility and freedom of locomotion. Almost every ring has a pair of lateral, finlike projections which enable the animal to swim or creep rapidly. Their possibilities will unfold in the appendages of insects.

The body is composed of two parallel concentric tubes, one within the other. The smaller tube, the intestine, opens at the front and hind ends of the body by becoming continuous with the outer tube. The opening in front is the mouth, that at the rear the anal opening. We will call the outer tube the body wall. It is composed of the skin and two layers of 
muscles; the fibers of one running longitudinally, those of the other transversely. These muscles can lengthen, shorten or bend the body as it writhes through the water. They also give complete protection to the delicate internal organs. The lining of the digestive tube secretes the digestive fluids and absorbs the digested food. As the food passes through it in a more or less continual stream its different parts have begun to differentiate to suit the different stages of digestion. The tube is far more efficient than the mere sack. Around this tube also are layers of muscular fibers.

The space between the two tubes is the perivisceral cavity or cœlom where delicate vital organs can be packed away. Here we find comparatively simple reproductive organs. Many eggs are still produced but this is not the whole business of life as in flat worms. We find a pair of excretory tubules in each segment to remove the steadily increasing nitrogenous waste. The earth worm still breathes through the outer surface; the more active clam-worm has little feathery or tubular gills on its fins. We find a complete system of blood-vessels to insure delivery of nutriment and oxygen to all parts of the body and removal of waste. The perivisceral cavity is filled with a colorless fluid, perhaps much like our lymph. All the essentials of the body of a very powerful and efficient animal have here been realized to a large extent. The general plan of structure and arrangement will be retained in higher forms though with much improvement in details.

A quite complex nervous system has been already attained. In every ring or segment of the body we find a nerve center or ganglion controlling the muscles of that segment. These are connected in a chain along the ventral surface sending forward on each side of the œsophagus bundles of fibers, commissures, to an evidently superior or supreme center in the first segment. The long cylindrical body is thus unified and brought under one control. This chief supra-œsophageal ganglion innervates the principal sense-organs. The mouth has the sense of taste, and here or hard by is located the 
sense of smell; the chief means of recognition of food. Tentacles form exquisite organs of touch and very possibly of other senses. The cells with fine hairs, which we found in cœelenterates are still abundant, and may be accessible to a variety of stimuli. Little sacks lined with similar hairs, otolith-vesicles, are probably organs of feeling delicate vibrations in the water, and giving warning of the nearness of foe or food. They are on the way to become organs of hearing.

We have found the eye as a pigment speck in flat worms and probably in primitive cœlenterates. In some of the flat worms such pigment specks have sunk below the surface and light is allowed to enter only along a single line of direction. The skin covering the aperture is transparent and if it thickens gradually into the form of a lens, and the pigmented surface becomes more delicately and fully innervated, we have an organ which is no longer merely photoscopic, light perceiving, but also eidoscopic, forming images of external objects. At least one annelid, alciope, has attained such a truly visual eidoscopic eye giving an image of objects within a very narrow range of vision.

We cannot overestimate the importance of the development of a visual eye. It may be crude and near-sighted, but " among the blind, the one-eyed man is king." Among higher types of animals an eye with some means of forming an image is universal. Eyes, otolith vesicles or ears, tentacles and other sense organs are all situated at the front end of a vigorous cylindrical animal writhing its way through the water. Here the watch and lookout for food and danger must be maintained. All these sense-organs are innervated from the supra-œsophageal ganglion which is continually pelted with stimuli from all sides and sources. It is growing fast but is hardly sufficient for the work and demands thrown upon it. The annelid can hardly be said to possess a true head and brain, but if it keeps its front end foremost and does not drift it will surely develop one. To adopt the expression of the stockmarket it is very "long in futures."

These annelids, and probably others somewhat like them, 
revolutionized the animal kingdom and marked out a farstretching line of advance. They alone were not the ancestors of all higher forms. Others are equally interesting and progressive, one is tempted to say aspiring. Sagitta, the "arrow-worm," could tell an equally fascinating story. Possibly or probably worms superior to both these have disappeared and left in the rocks no trace of their soft bodies. But several forms of these highest worms were tending and struggling and writhing in a very interesting direction.

Let us choose any one of these highest worms which has the muscular locomotive body with a front end possessing crude visual eyes and good ganglion. Let us imagine him as having a pharynx or muscular lining of the mouth which he can protrude, and that this pharynx is armed with a couple or more of sharp, pointed, claw-like horny teeth. Let us turn such forms, and there are at least some of them still surviving, loose in an ocean swarming with less active unarmed lower worms and colenterates. They will live like kings and own the world. No unarmed form can stand before them. The world of cœlenterates and flat worms was one of comparative peace. Two jelly-fishes cannot fight if they would; two annelids might, and their descendants will. The struggle of brute with brute for supremacy has begun or is near at hand. Only the most vigorous, tough, athletic, vigilant and wary can hope for success. The worms are entering or approaching this arena and the gladiatorial shows will continue for millions of years. Something magnificent must surely come of it. Even if we are descended from worms, they were glorious worms! 


\section{THE COMING OF A BACKBONE}

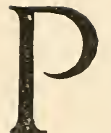

EERING backward into the dawn of geological history, where even the palæontologist can help us but little, we see dimly a vast ocean peopled with a swarm of worms and cœlenterates, as well as all sorts of still lower life. The age of pacifists, of universal flabbiness and peace, is passing fast. It was high time to begin the development of some sort of skeleton. Three different types of skeleton were possible. Different descendants of worms experimented on these three lines and thus became ancestors of the highest groups of animals: vertebrates, arthropods and mollusks. These three ancestral, pioneer worms parted company ages ago, and all unconsciously went out into the world to seek their fortunes. The vertebrate ancestor developed an internal locomotive skeleton which was to culminate in a backbone. The arthropods are represented by insects, spiders and crabs. Their ancestor secreted an external horny skeleton, chiefly for locomotion, partly for protection.

The primitive molluscan ancestor was apparently an unsegmented worm crawling slowly and lazily over the bottom where small food was abundant. Here, where life teems, some sort of protective skeleton seems almost the rule. There are shelled protozoa, coral-animals and sessile well protected worms. The skin takes easily and naturally to producing such a skeleton, and very likely it developed rapidly. He crawled slowly on the bottom, and his mode of life gradually molded his whole structure.

We will first glance at the clam, the extreme logical conclusion and in a way the consummate flower of molluscan 
development. We will not weary ourselves with dry details of anatomical structure; we seek chiefly the tendency and results of his experiment and line of advance, his gains and losses. The ancestral clam developed a shell composed of two valves which extended downward and completely covered the sides of the body. It burrowed in the mud or sand until well out of reach of any large foes - if any such should ever arise - where he was safe even from nibbling worms and boring irritating animalcules. Against all forms of pain and discomfort he offers an even more impregnable defence. He has little muscle, except enough to close the shell, less nerves, and his supra-œsophageal ganglion is minute. Most irritations are unnoticed; severe or sharp pain is probably impossible.

Some morbid soul may think that a being to whom pain is impossible cannot know happiness or pleasure. The clam distinguishes his food, and his senses are continually tickled by a stream of appetizing particles floating down his throat. Fear and worry are certainly unknown to him. If unalloyed comfort is the goal of evolution, the process should have ended with the clam.

The criterion of fitness, according to Mr. Darwin's theory, is survival due to conformity to environment. This the bivalve mollusks have attained, and without any great effort or struggle. They were already ancient forms when the first mammals appeared some millions of years ago. They have lasted well. They have a large surplus income to devote to reproduction. The eggs are small because the young can be born in a very simple stage and still shift for themselves. The infantile danger period is short. They have been fruitful and multiplied.

Many animals have found a temporary environment of abundance and comparative peace, to which they have closely conformed, and have therefore prospered. But when conditions changed, they were the first to suffer and disappeared. The clam has accommodated itself to life in a strip of shore where sea and land meet. As long as sea and land endure 
they will meet in shores. He has apparently conformed to a vast, favorable, unchanging, everlasting environment.

Our sketch of the clam has given us but a partial and onesided view of molluscan history. The clam represents only one of three great subdivisions or classes of the whole subkingdom. The second class of mollusks, the gasteropods, includes the recent forms having a single spiral or conical shell, or having the foot in the form of a creeping disk. They generally crawl on the sea-bottom. They have spread into brackish and even into fresh water. Some of them have used the sack or chamber which contained the gills as a sort of lung, have breathed air and emerged on land. Our snails are descended from such forms. Some have taken possession of cracks and fissures in the rocks, or have worked their way deep into the mass of fragments under limestone cliffs. Slugs are snails which have given up the cumbrous shell as no longer needed for protection.

All these forms are most at home in damp or wet localities. They still betray their origin from aquatic ancestors. It need not surprise us that some of the air-breathing mollusks returned to the water again, and became pond-snails.

Some of the marine gasteropods have lost the shell, so the sea-slugs, nudibranchs. But even among the more typical gasteropods some have returned from the crawling life of primitive mollusks to the swimming habit of still more primitive ancestors. The most noteworthy of these are the pteropods. They have either greatly lightened or completely lost the shell, have changed the broad creeping disk into a pair of winglike fins by means of which some are said to dart through the water much as butterflies glide through the air. One group of these pteropods has retained a light shell. Its members feed on the small plants and animals which swarm in the ocean. They also attained an exceedingly wide and stable environment and have held their place since the beginning of palæozoic time.

The second division has given up the shell, and its members lead a carniverous hawklike life feeding on their shelled 
relations. Pteropods swarm in the northern parts of the ocean, and form quite a large part of the food of whales as well as of fish. Thus the clams possess an immense territory of shore and the pteropods the almost boundless surface of the colder oceans, an unequalled distribution which they hold almost without competitors.

Both clam and pteropod live on microscopic food, which is constant in supply and easily obtained. They hold a somewhat humble and unostentatious, but most important place in Nature's vast household, corresponding in a way to the insects and smaller vertebrates on land.

It was left to the cephalopods, the third great class of mollusks, to attempt a more ambitious rôle. They also forsook the crawling life of their more primitive ancestors for some reason unknown to us. Perhaps they gained larger and better food in this way; possibly in the severe competition on the bottom they were forced to the change of habit by stronger and better adapted opponents.

They invented or stumbled upon a very ingenious mode of locomotion by taking water into the so-called mantle-cavity and then spurting it out between the lobes of the foot in a powerful jet. Modern squids and cuttlefish have united these lobes in a tube, the siphon. By this peculiar method they move with marvellous rapidity, darting through the water like the swiftest fishes. At the front end of the body around the mouth they have developed a circle of long arms bearing rows of suckers so that they can grasp and hold firmly anything which comes within their reach. Many modern forms have a beak like that of a parrot with which they can bite directly through the body of an ordinary fish.

The swift locomotion developed the muscular and nervous systems to an extent unknown among other mollusks. They have large eyes and organs like ears, and a well developed and distinct head. Their brain is large and complex and surrounded by a sort of cranium. Their shells grew continually lighter. In the squid the external protective armor has been completely cast off. Theirs is no defensive campaign. Only 
rudiments of the old skeleton remain as a sort of a quill which has sunk beneath the skin and gives to the body some of the support furnished by our backbone. It was a bold and difficult experiment and was for a time marvellously successful. The cephalopods were the rulers or vikings of the early palæozoic seas. No form could begin to compete with them in size and strength. They ruled supreme.

The vertebrates came upon the scene. Sharks and ganoids were equally swift and had far more efficient jaws. The cephalopods held their place with marvellous pertinacity. Far down in Mesozoic times we find the shells of the ammonites very abundant. Possibly the extinction of this great group was due to climatic changes rather than to competition. Certainly the ammonites disappeared. Nautilus is their last surviving near relation. The squids and octopi alone remain of a host of related ancient groups. It is a hopelessly defeated form, a sad relic of decayed power and greatness.

Most of our recent squids are of only moderate size. But the body of architeuthis, the giant-squid, is more than eight feet long; while the arms are over thirty feet in length and as thick as a man's thigh; the suckers are as large as coffee-cups. They have been reported from Labrador and Newfoundland, Iceland, Japan, and are apparently deep-water forms of almost universal distribution.

A struggle in which squids have been worsted and devoured by fish or even by sperm-whales is a very homely or vulgar sort of tragedy. But let us look a little closer. The ancestor of the squid forsook or refused the crawling life and became free-swimming. This is a step which through the development of muscles, nerves, sense-organs and brain leads to progress. Even sense-organs and brain are stimulated and fostered by muscular locomotion. The goal of early evolutionary progress seems to be first brute strength and toughness, then quickness and agility of motion and flexibility of body. We shall see that the vertebrate arose from insignificant beginnings mainly because of its constant exercise of its muscles. The squid played the great game according to its best rules, just 
so far as was possible to him. He failed through no fault of his own. He was doomed to failure by his earliest molluscan ancestors. He could rid himself of his shell, but the short, clumsy unsegmented body was fastened indelibly upon him by heredity. From this he could never escape. This is the tragic chapter of molluscan history. It seems to me worthy of that name.

Arthropoda. The external skeleton of the arthropods has the double advantage that it can be used either for protection or locomotion. In barnacles it is as completely protective as in the clam; in most crabs, and in many beetles, it serves very largely the same purpose; in spiders and many insects, like flies and wasps, it is almost purely locomotive. The value of so wide a range of adaptability is evident.

The arthropods form a series extending and completing the annelid line of development. The body consists of the two concentric tubes, the intestine and. body wall, with a perivisceral cavity between them; the nervous system has the same tyce, a ganglion in every ring of the well segmented body. Both have on some or most of the segments of the body a pair of appendages; fins in annelid, jointed legs or their modifications in the arthropod. The insects have added two pairs of wings in connection with their terrestrial or Aerial life.

The insects have grouped the segments of the annelids in three body-regions: head, thorax and abdomen, and have हुํlded each region for a special function or purpose. The tabdomen is usually composed of from nine to eleven segments, and is the chief seat of digestion, excretion, circulation, respiration and reproduction, the organs of vegetative life. To the Three segments of the thorax, two pairs of wings and three pairs of legs are attached. These segments are very closely united, and in bees and flies are fused in one globular mass.

The head consists of six, or possibly more, completely fused segments. The appendages of three of these behind the mouth have been changed into as many pairs of jaws, or still further 
modified to form piercing or sucking mouth-parts. Three preoral segments carry the large facetted eyes, and a pair of antennæ; organs of feeling, often also of smell and hearing. Originally every segment had its nerve-center or ganglion. In insects the ganglia of the three preoral segments of the head are fused in what we must call a brain sending its nerves to antennæ and to genuine visual eyes. The antennæ are very sensitive organs; the eyes are often very complex giving clear and sharp vision of objects at some distance. The insect is well aware of what is going on about it.

Insects evidently live on a distinctly higher plane of life than any of the forms which we have previously studied. Coelenterates are stationary or scarcely more than floating and drifting animals; and we can hardly speak of muscular and nervous systems. Lower worms crawled slowly but developed steadily muscle and nerve. Insects devote only about half of their body to the vegetative organs. The thorax is purely locomotive, and the front half of the head entirely sensory and nervous. This is progress which almost amounts to a revolution. Hence in all insects we find very highly developed instincts, and some intelligence in bees and wasps, which have also developed a high grade of social life. Insects are a very promising group; we naturally expect great things of them.

They were Nature's precocious children, made rapid progress, and had advanced far in early palæozoic time. Their development culminated with the appearance of bees and wasps in Mesozoic or early Cenozoic time. Since that time their progress seems to have ceased. This is a strange fact, which demands careful attention.

The external locomotive skeleton is admirably fitted to an animal of small size. To encase an animal of the size of a dog in such firm armor would surely hinder locomotion; it would be difficult to frame the joints, and the successive moults required to meet the growth of the body would be impossible. We have seen the great advantages of small size; it has also its marked limitations. The small insect could never hope to 
compete directly with the large and powerful vertebrate. More important still small size seems to be usually correlated with short life. The life of the full-grown insect rarely exceeds a few months and is, as a rule, much briefer than this. The larger vertebrates live for several or many years.

A brief span of life is not productive of intelligence born of long, oft repeated, but varying emergencies and experiences. There is little opportunity for the individual to learn thereby. In the rapidly recurring and succeeding generations successful habits, or mental peculiarities quickly become fixed, and are handed down practically unchanged as inherited instincts. There is little stimulus or opportunity for mental growth in an animal whose whole experience is limited to a few months of easy and enjoyable summer. The whole subject of instinct and intelligence, their resemblance and differences, compensating advantages and disadvantages, especially their origin, forms a field of most fascinating study, into which we will not attempt to enter.

We can only glance at the early individual development of insects. Excepting a very few of the most primitive, they all attain their adult form through a metamorphosis most marked and complete in the highest and latest forms. The butterfly is born a caterpillar, the bee a sort of grub, the fly a maggot. The advantage of the metamorphosis is evident. We have seen that every egg must contain enough nourishment to feed the embryo until it reaches a stage where it can shift for itself, and the simpler the animal at birth, the shorter the embryonic life, and the less nourishment required in the egg.

Out of a given amount of surplus material to be devoted to reproduction, a few large eggs or many smaller ones can be formed. It is a great advantage to the species that the eggs should be as numerous as possible, and that to gain this advantage the young are born in as simple and incomplete a form and as quickly as possible. Hence the butterfly is born in a caterpillar stage, and must gather, assimilate and store up 
sufficient nourishment to complete the growth and development from the larval to the adult stage.

If the metamorphosis or series of changes from larva to adult is comparatively easy it requires no long resting stage; even if great and difficult, it may be distributed along the successive moults, or all be condensed in the cocoon or resting stage of the so-called complete metamorphosis. This explains the voracity and destructiveness of insect larvæ. It does not surprise us to find that the most destructive insect pests are usually the smallest, like the plant lice, for example. Where limited locomotion or sessile life is added to small size, as in the scale-bugs, the insect becomes a veritable scourge.

Insects disappoint us. Their good qualities and powers are many and marked; their limitations are equally clear and in time seem to have put an end to progress. The external skeleton gives good returns for a long time, but leads to standstill in the end. Life must and did produce something capable of surer and less limited progress.

\section{The Vertebrate. The internal locomotive skeleton.}

The ancestors of vertebrates or backboned animals, the primitive chordata, neglected all the advantages of protective armor, and placed the skeleton inside the body as near its axis as the large vegetative organs permitted. The primitive skeleton was a rod of spongy tissue which, for lack of a better name, we call cartilage. It is sheathed by a layer of fibrous connectile tissue, which in time gave place to true cartilage. This sheath sends projections upward to arch over the dorsal nerve-cord and downward around the great blood vessels. Sheath and arches furnish attachment for two heavy bands or masses of muscles running lengthwise on each side of the body. These may at first have produced a writhing motion, but later they pulled the tail-fin right and left alternately and sculled the body through the water.

The head is large with eyes, ears and nasal capsules. The 
eyes have the possibility of sight at long range. Smell and hearing are keen. The first chordata seem to have lived on minute food, sifting it out of the water with their gill-sack. Then jaws were developed armed with rows of sharp and pointed teeth. The sense-organs are innervated from a brain containing, even in the most primitive forms, the nervous material of some five segments, later of probably nine and even more. Powerful muscles and a large brain characterize this group from the earliest times. The revolution prophesied in worms has been accomplished. They swim far and swiftly, continually meeting new experiences and dangers throughout the years of a long life. Surely some of their descendants will become intelligent.

Such changes take time and can come about only very slowly. Millions of years must have elapsed before a form somewhat like amphioxus could have changed even into the most ancient shark. Cartilage had to be discovered, invented, hit upon and improved - express it as you will. It could arise only under strain in the fibers of the dorsal fin-rays; it gradually extended downward on the arches over the nervous chord, thence into the sheath of the notochord. We wonder that the process was ever carried to a successful issue. They looked like anything but promising forms.

But replacing fibrous tissue by cartilage was only the first step. The only bone in a primitive shark was in the minute scales or denticles of the skin. How some ancient ancestor had succeeded in developing bone, in many respects the most marvellous tissue in our bodies, is beyond my comprehension or imagination. He did it.

Bone also worked its way downward from the surface along the rays and spinal arches, as cartilage had preceded it; and finally replaced the cartilage. In time vertebræ were shaped and the animal had a backbone. We might say that vertebrates built three skeletons in order to gain the beginnings of a backbone, a marvellous series of changes.

We may glance at the structure of a shark as a very primitive form of vertebrate animal. We notice the long cylin- 
drical body tapering to the solidly muscular tail with its curious fin. All the vital organs are well developed and exceedingly compact. We notice the well marked head, the strange position of the mouth, the keen sense-organs, and the large brain. Indeed the brain looks larger than the needs of a shark require.

We find only two pairs of lateral appendages, the fore and hind fins used mostly for steering. This is a sharp contrast to the many pairs of appendages of the arthropods, every pair admirably adapted to a special purpose. We will return to this fact later. We find a skeleton in which the ancient notochord is being crowded upon by the cartilaginous sheath. This sheath may be infiltrated and stiffened with carbonate of lime, forming calcified cartilage, but no true bone. The skin feels like sand-paper; it is covered with minute pointed scales or denticles composed of bone covered with a layer of enamel. The scales covering the skin of the jaws have enlarged greatly and become triangular teeth, of which there are several or many rows.

The dog-fish is an admirably framed and fashioned animal: powerful, agile, swift and enduring in locomotion, tough and vigorous, with keen sense-organs and no mean brain. It roams everywhere; especially over the sea-bottom, where food is most plentiful and the struggle fiercest, and is continually meeting new conditions and emergencies. Its eggs are very large, yet it is extremely common. Evidently even the young are well able to care for themselves. No wonder that the fishermen hate and curse it; it is the highest tribute to its many virtues.

Almost or quite as old as the sharks are the ganoid fishes represented by the sturgeons, garpikes and a great host of fossil forms. In the structure of the notochord and sheath they show us all stages up to bony vertebræ. They differ from sharks in one important respect: they have an air-bladder, a sack connected with the mouth by a tube through which air can be drawn. They have the possibility of using the air-bladder as a lung, and some of them have realized and 
utilized this to a fair degree. The brain looks smaller than the shark's, but it is well formed and may be more compact and highly differentiated. We shall see the importance of the ganoids in the next chapter. 


\section{III}

THE RISE OF LAND LIFE

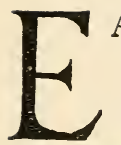

ARLIEST Palæozoic time seems to have been characterized by seas of wide area. Its deposits are largely limestones laid down in fairly deep water. The earliest known foot print of a terrestrial vertebrate is in sediment belonging to the upper devonian period; the animal had already emerged on land, perhaps during the lower devonian period, when the land began to rise, and shallow water, or bays and rivers were extensive.

The weight of geological evidence seems to favor the view that both sharks and ganoids developed in fresh water out of some more primitive immigrant ancestor from the sea. ${ }^{1}$ Here there is still much uncertainty. But we may be fairly confident that the ganoid stock at least was chiefly represented in the rivers of the rising continents in early devonian times. The ganoide, sturgeon, garpike, and others, show wide variety of form and structure. They differed greatly in the form and thickness of their scaly defensive armor. I believe that we may safely imagine that the well defended forms would hold the channels of the rivers and the lagoons, while those with least defensive armor would be driven into the shallower waters and swamps.

The climate of this period seems to have been semi-arid, seasons of pouring rain and floods alternating with drought. Under such circumstances the air-bladder capable of inhaling atmospheric air would have been of great and steadily increasing use and value, especially in the headwater marshes, where in the hot summers the gases of decaying vegetation

${ }^{1}$ H. 462 . 
would have fouled the water. It slowly became a lung. In these marshy pools overgrown during the wet season with all sorts of weeds and plant-life, the paddle-like fins would have been of little service to forms hovering or crawling along the bottom; they became jointed and changed into legs, and gradually the amphibious animal emerged more and more and ventured out on the land.

Much still remained to be done before the body was fully shaped in all its parts. The blood-system had to be enlarged and modified in connection with air-breathing. The lungs became more complex and spongy, offering a larger respiratory surface. In the thick growth of ferns and club-mosses the eyes were for a time of less use than the sense of smell, and the higher development of this sense reacted on the brain. The skeleton of a form supported by four legs, rather than floating or swimming in the water, gained increased strength and stiffness. In backbone and skull and elsewhere cartilage was replaced by bone under the stimulus of new strains. The muscular system of shoulder and thigh became heavier and more complex, that of the trunk began to lighten.

Perhaps the most important change of all was the rise of temperature in the body. In the better conducting medium of the water the heat produced within escaped rapidly and was lost. The temperature of the body of a fish can be only slightly higher than that of the surrounding water and varies accordingly. Heat radiates into air far less rapidly, hence the temperature of the body gradually rises. It is still variable in amphibia and modern reptiles, in mammals and birds it will become constant and high.

All chemical changes go on more rapidly as temperature rises, but all organs are not equally affected. The more unstable the material of the tissue, the greater the quickening of the changes. Cartilage and bone are slightly stimulated, muscle far more; the markedly protoplasmic structures like nerve-centers and glands will be stimulated most of all, and their development will be hastened proportionately.

Life on land brought new difficulties and dangers but also 
release and escape from old limitations into a host of new possibilities. Says Lull: "The sea is so changeless and the range of its conditions so small that evolution within it is not stimulated as it is on land." 2 Life is far more complex. The animal is continually pelted with new stimuli and experiences; hence the large size and accompanying long life of the individual, the storing up of the results of these experiments in the growing, changing impressible brain. Not yet, but some day, the land-vertebrate will become intelligent.

But life on land and in the air initiated changes of greater importance though of far slower realization than any which we have yet noticed. The development of the muscular and nervous systems is accompanied by a more rapid combustion of food material; they are expensive luxuries. Hence, as we have seen, the surplus devoted to reproduction, enormous in parasites, very large in sessile or slow moving forms, is fast sinking to a minimum. Yet speed and muscular and nervous energy will increase still more rapidly from this time on.

This rapid decrease of surplus for reproduction is a danger signal; it suggests or threatens race suicide. We remember that the number of eggs must be inversely proportional to their size; and the size of the egg is determined chiefly by the amount of nutriment required to support the embryo until it can shift for itself. This again is determined by the complexity of the animal and the conditions accompanying its birth. If a form is born in water, like a fish or tadpole, it can almost float to its food. It swims by vibrations of the tail, and thus requires only the action of masses of simple trunk muscles stimulated and controlled by a very simple nerve-center. The animal born on land must walk to its food. This demands a considerable development of complex sets of muscles controlled by a correspondingly complex brain. This again demands a steadily lengthening period during which the embryo must be supported, boarded as it were.

In one word every egg of an animal born on land must be far larger than of one born in the water. The young of am-

$2 \mathrm{H}: 479$. 
phibia are born in the water, those of all higher animals on land. The eggs of the amphibian are far larger and less numerous than those of the average fish; but far smaller than those of reptiles. The decrease in the number of eggs is alarming. Fish produce eggs by thousands or even millions, amphibia by hundreds, reptiles perhaps by tens, birds and mammals by still smaller units.

This condition can be remedied and its dangers averted only by a steadily increasing and best possible care of the young. We find little of this in most reptiles, much in birds; in all higher mammals the eggs are carried in the body of the mother until birth, and the care of the young is continued for a steadily increasing infantile period after birth, which in higher mammals and man is followed by a period of childhood. Emergence on land revolutionized vertebrate life; evolution in the face of limitations and opposition often becomes revolution. The ice formed during a long hard winter blocks the channel and holds back the gathering flood. Either the ice gives way or the water seeks and ploughs out a new channel to its goal.

We have left our amphibians far behind and must return to them and their descendants. The mud-puppy of our lakes gives us a good example of a primitive amphibian; the newt or salamander of a far more advanced form. Frogs and toads represent a late, greatly modified and very peculiar branch.

From some primitive amphibian the reptiles diverged in all directions. The primitive reptiles were creeping forms, sometimes dragging the body on the ground. But the legs soon strengthen and lengthen as in lizards. The reptiles soon outgrew the difficulties of land life, found abundant food and easy place. They were very precocious and advanced rapidly. During Mesozoic time there were running, striding and even flying forms. The huge, well-armed dinosaurs ruled the world, and it seemed as if no other form could ever compete with them. It was a marvellous class of vertebrates with a fascinating history into which we have no time to enter. 
Their defeat or senescence, failure and practical disappearance is still hard to understand.

From some not very primitive reptile, birds are descended. If swiftness of locomotion is the goal of animal development, it culminated in birds. Coördinated with and stimulated by their swift locomotion is the high development of the senseorgans in the head, the look-out of the flying-machine. The eyes are enormous, the sense of smell is exceedingly keen; song suggests well tuned ears. The body is compact and light to the last degree. The light stiff skeleton is a marvellous piece of engineering architecture. The back-bone, completely ossified, stiffens the body for flight. The bones of the shoulder girdle are admirably modelled and arranged to meet the strain of the heavy muscles which produce the downstroke of the wings. The head is lightened by replacing jaws and teeth by a horny beak, the tail shortened correspondingly. The heaviest organs in the short trunk are located as far as possible just beneath the line of support, joining the sockets of the bones of the wings. The weight of the body is lessened by reducing the least useful portions of the vegetative organs. The respiratory organs are arranged so as to supply oxygen to all parts of the body with the smallest weight and least strain on the heart.

The scales of reptiles have mostly become feathers, marvellous structures, combining lightness, elasticity, durability, and protection against cold and wet. The combination of great energy and food-combustion with the warm covering gives the body a constant temperature some ten degrees Fahrenheit above that of higher mammals. There are no sweat glands to reduce it. We expect a very high development of the brain. Here we are somewhat disappointed. In intelligence, at least, the higher mammals seem decidedly superior.

The eggs of birds relatively to the weight of the adult body are much larger than those of reptiles. But the young are usually born entirely incapable of caring for themselves and are tended, fed and protected by the parents for several weeks. They are few in number; in certain shore-birds only 
one or two at a season, yet these birds often appear in vast flocks at their remote, solitary and inaccessible nesting places. To reach these breeding-grounds long migrations are often necessary, an important subject into which we cannot enter.

The bird will always be an object of fascination both for its attainments and its limitations. Structurally and anatomically as a flying-machine, it is unsurpassed and seems unsurpassable. It disappoints us, perhaps because it is a finished product. It seems to have reached its culmination. Perhaps, as a bird, it is as nearly complete and perfect, as it well can be.

Mammals are in many ways less interesting than birds. There is nothing spectacular or even very striking in their history. They have always been plodding, slowly progressive forms.

The skeleton is entirely ossified and well molded and framed, but heavier than in birds. The vital organs are, as a rule, in no way superior to those of birds. Their slower locomotion makes exceeding keenness of sense - except perhaps of smell - less important. Their temperature is lower by some ten degrees Fahrenheit, as we have already seen.

They started with a covering of scales like those of primitive reptiles, from which they seem to be descended. These scales have been retained as a covering for the body in a few forms; and still persist on the tail of some rodents, as the rat. In primitive forms the legs are stout but short, as in most recent reptiles. They laid eggs like reptiles, and this habit is still retained by echidna and platypus in New Zealand. Could we have seen these primitive animals running or shuffling over the ground, we could not have considered them very promising. Appearing in the Cretaceous period at the end of Mesozoic time they long remained completely outclassed by the reptiles and began their period of rapid development and rise to supremacy only in Cenozoic time. ${ }^{3}$

${ }^{3}$ We may yet return to the older view that they had appeared in Triassic times. 
The feathers of birds are modified scales; the hairs of mammals originated as sensory organs, somewhat like the "whiskers" of a cat. ${ }^{4}$ There were perhaps three of them protruding from beneath each scale. These sensory hairs increased in importance, perhaps under the stimulus of a cooling climate, multiplied and became a coat, while the scales gradually disappeared. The original use of these hairs is hard to determine. They may have been of use in the crannies and dark corners whither the mammals took refuge when hunted by the reptiles.

The next group of mammals after the egg-laying monotremes, like platypus, was that of the marsupials. Here the female carries the eggs and embryos in the uterus without any placenta or organic connection between mother and young. This embryonic and fotal period is very brief. The young are born in an immature condition and are carried and suckled in a marsupium or pouch until able to care for themselves.

Placental mammals seem to have quickly outgrown the marsupial stage. In them a fœtal membrane has put out projections which interlock with similar projections from the lining of the uterus of the mother forming the placenta. Hence oxygen and nutriment can diffuse through the thin membranes separating the blood-vessels of the mother from those of the young. Its fotal stage can now be greatly lengthened and birth delayed.

The Eocene, the earliest period of Cenozoic or Tertiary time, shows us placental mammals already distributed in their chief orders. It appears to have been preceded by a colder epoch at the close of Mesozoic, and this may have contributed to the downfall of reptiles whose most highly developed forms have now disappeared. From this time on placental mammals multiply and become more diversified. Insectivorous forms lead over to true carnivora; rodents, represented to-day by rabbits, squirrels and mice, have appeared. We find ungulates, like cattle, deer and horses, with hoofs, and with 
teeth adapted to a browsing or a grazing diet. They have lengthened their legs and become swift and wary. Every one of these and other orders adapted itself to its own place, food and conditions, and met and solved the problem of the struggle for existence in its own way.

The primates, including monkeys and apes as well as man, are represented in Eocene deposits by forms akin to the lemurs or "half-apes" whose center and chief home is now in Madagascar. They may have originated in the northwestern part of North America. From this region one branch went southward and gave rise to the South American monkeys with prehensile tails and a rather poorly developed hand. A second branch migrated into Asia, and from these the catarrhini or old-world apes are descended. At the head of the apes stand the anthropoids: the gibbon, the orang, the chimpanzee and the gorilla. Every one of them approaches or resembles man in some respect more closely than does any other of them, and every one differs from him in certain important characteristics.

The most important and influential characteristics of all the anthropoids is their arboreal character. The squirrel runs up the trunk of a tree or along its branches holding by its claws. The primates are larger forms. They stand on one branch and grasp another above them with their hands. They are genuine climbers, differentiating hand and arm sharply from foot and leg. They have not closely adapted their teeth to any one kind of food as nearly all other groups of mammals have done, but are practically omnivorous. This characteristic was a great advantage to their descendant man, to whom almost any kind of food was welcome.

We can hardly imagine a better school for the training of our primate ancestor than arboreal life. He had to train arm and hand to a great variety of very different and precise movements. Wallace tells us that the orang in the tropical forest can swing himself from branch to branch and tree to tree as fast as the hunter can follow it on the ground below. This is the best training possible at this stage for the de- 
velopment of the brain. It is a sort of course of manual training in the use of eye and hand.

In leaping from tree to tree eye and brain must see, measure and recognize exactly the direction, distance and strength of the branch and the right point to be grasped. The body must be hurled in exactly the right direction with the proper amount of force. Hand and arm must be extended so as to grasp the right point at the critical time. All this series of observations and complex movements is probably, or may be, worked out and completed with little conscious thought. But the capacity for executing the movement has crystallized out of a long series of experiments, and demands an exceedingly complex brain for its performance. We do not wonder that the anthropoid brain shows us a clear ground plan of the brain of man with all its centers represented, though often very incompletely.

The process of evolution began with organs of digestion used mainly to supply material for reproduction. The whole aim of life seemed to be to increase and multiply, to exist and survive. Then muscles crept in as means of getting food and escaping danger. These occur at first as heavy masses of trunk muscles giving at best only writhing locomotion. Then appendages appear at first mere unjointed fins like paddles. Then jointed appendages arise, at first weak, short and clumsy, then strengthening and lengthening with steady increase of freedom and precision in the movements of different parts, especially of the distal parts as evolution shifts its field from the stout heavy clumsy fundamental muscles of the trunk and shoulder to the numerous small and fine muscles of hand and finger. The ape has learned to use the hand as a whole grasping organ, it was left to man to develop the vast variety of movements and their combinations so characteristic of the skilled artisan or technician.

Every increase in muscle means and demands a corresponding enlargement of the nervous system. Increased number of finer muscles and combinations of more precise movements demands a larger number of more complex centers 
brought under the control of the seeing, combining and controlling brain. Training of the hand and finger under the direction of the eye means mental development. The brain of an anthropoid is an organ of vast complexity which bristles with possibilities. The ape is no longer a mere reflexive or instinctive machine. He learns by experience and has far more than a dawning intelligence. He has achieved much, he is still indefinitely far from anything approaching complete attainment.

Arboreal training can do little more for him. Complete adaptation to arboreal life might make him a sloth. It is high time he was promoted to a different school with more difficult problems better suited to awaken his dawning powers. But "there's the rub." That school must be on the ground which is in possession of the keen, swift, athletic, gladiatorial well-armed carnivora. He is weak, defenceless, unfitted for swift locomotion on the ground. The chances are all against him. Why should he descend? Nature seems to have blundered. She has given the weapons, skill and strength to the brute; the better brain with all its possibilities is in the head of a weakling. She ought to have kept them both combined in one individual or group. Now they are hopelessly separated. The outlook is certainly anything but encouraging. 


\section{THE COMING OF SAVAGE MAN}

AYS Lull of modernized or now existing mammals: "They are all creatures of high potentiality, and, where they became extinct, were rather the victims of circumstance than creatures which died bcause of lack of adaptability: although certain groups seem to have run a natural course and their extinction was heralded by evidences of racial senility."

"As the archaic forms were characterized by lack of progressive brain and teeth and feet, so the modernized races were distinguished by the possession sometimes of one (primates), sometimes of two (elephants), again by all three (horses) of these destiny controlling organs, but in general the modernized animals were progressive, highly adaptable forms. ${ }^{1}$ We might say they were "educable."

They seem to have originated in a circumpolar region which in early Cretaceous days enjoyed a warm, equable climate. The flora of the coast of Greenland was subtropical, and a temperature like that of Cuba to-day spread over Spitzbergen and Alaska also. Through early Cenozoic or Tertiary time there was a gradual cooling of climate and corresponding southward migration of higher plants and mammals.

Among these were our primates of whom Lull says: "It is only in the brain and such correlated modifications as mental development entails that the primates may justly lay claim to superiority, for in other respects they are as humble and generalized a group, with very few exceptions, as the mammalian class contains." 2

1 H. 560.

$2 \mathrm{H}: 642$. 
We may well imagine these primates as slowly crowded out of northern Europe and Asia. The Alps in Europe, the Black and Caspian Seas, with the Caucasus mountains between, barred the farther escape southward. Between these western barriers and the great eastern Himalaya elevation lay Western Turkestan and the uplands of the Iranian plateau. Even here the increasing coolness and dryness of Miocene and early Pliocene times were causing forest to give place to ever widening stretches of open grassland. The tropical and most of the semitropical trees have been driven farther southward. It is no longer a suitable home for arboreal forms depending upon trees for home and refuge, and fruits for a good part of their food.

Most of the anthropoids continued the southward retreat. Gorilla and chimpanzee went into Africa; the orangs entered India and thence the long Malay Peninsula to what are now islands in the Indian Ocean. The gibbons seem to have lagged behind in this southward march.

Following these immigrants was one group which had apparently lingered still farther behind. They may have come from farthest north. They had been the last to retreat, had been toughened by the cooling climate, hardened and trained by the diminishing supply of the most easily obtained and attractive food. Either caught in some dwindling forest region or open park-land or tempted by the richer supply of food on the ground, they began to venture to come down from the trees; to search for roots and bulbs, berries and similar fruits, insects and their larvæ, and the small animals living along the streams. It was a hazardous experiment; but they made it, somewhat from inclination, far more by compulsion. Thus we may imagine or guess that the final and for them irrevocable step was accomplished.

It was anything but a safe or promising venture for an arboreal form. The ground belonged to the carnivora; powerful lithe forms, with sharp claws and teeth, of speed and skill in stalking and springing upon their prey. The anthropoid had led a safe peaceful life, and had remained without 
weapons or armor. Against their strength and wiles he could pit only his few brains and poor wits. His bare hands availed him little or nothing. It would have seemed to any intelligent onlooker a hopeless struggle. The remaining trees must have been a welcome refuge long after they ceased to furnish a permanent dwelling place.

The legs gradually lengthened and strengthened with the habit of walking. The arms shortened somewhat; the hands were used for a variety of new purposes. They were the only tools of our anthropoid ancestor. The eyes were always watching for every dim and remote sign of attack, the ear intent to catch the faintest warning of approach of danger. This was a new schooling, very different from the manual training or gymnastics of arboreal life. The tests were exceedingly severe; only those who "took honors" survived.

Whether the orang ever intentionally throws down handy missiles at his enemies may still be doubted. It is hardly beyond his skill or intelligence. Our ancestor must soon have learned to throw a handy stone or use a convenient stick against smaller enemies. To have used a sharp stick for digging would have required an intelligence no greater than that of the young gorilla to-day. If he is learning to eke out the weakness of his hands by addition of stick or stone, he has started on the endless road of tool-using and device, of discovery and invention.

At Trinil, in central Java, Dubois discovered somewhat scattered remains which appear to have belonged to one individual to which he gave the name of pithecanthropus erectus, or the erect ape-man, and which seems to stand midway between man and the apes. The remains consisted of two molar teeth, a thigh-bone, and the top of a skull. The cranium is low, the forehead exceedingly retreating, giving but very small space for the frontal lobes of the brain. The brain-cast, made from the cranial cavity, shows, according to Dubois, that the speech area is about twice as large as in certain apes and only one-half as large as in man. In size the brain stands somewhat above midway between the highest recent apes and the 
lowest existing men. The thigh-bone shows that pithecanthropus could have stood and walked erect quite comfortably. There has been and still is much difference of opinion as to the exact position of this interesting being. Opinion was long divided nearly equally between those who considered it as the highest ape and others who held it to be the very lowest man.

Whether we think that pithecanthropus was approaching or had already passed the threshold of manhood depends much upon where we draw the line between ape and man, a line largely artificial and as difficult to fix as the day and hour when the youth becomes of age; and what human characteristics we select to mark it. In his erect posture and some other physical traits he seems already to have attained manhood, mentally he was probably inferior to even the lowest savage races of to-day.

Says Osborn: "Certainly Java was then a part of the Asiatic continent and herds of great mammals roamed freely over the plains from the foot-hills of the Himalaya Mountains to the borders of the ancient Trinil River while similar apes inhabited the forest. At this time the orang may have entered the forests of Borneo, which are at present its home." 3

We have seen that the anthropoid apes went southward into the Malay Peninsula or turned westward and then southward into Africa. The Negritos, the most primitive human peoples, are found to-day in India and the islands of the Malay Archipelago; while another branch became the pigmies of the forests of central Africa. The negroid tribes seem to have followed the same courses. It was the line of least resistance leading to lands where food was abundant, climate kindly and life easy. To this environment and its modes of life and few demands they cheerfully conformed.

Migration from the Iranian Plateau is open in all directions. ${ }^{4}$

3 24:77.

H. 676 .

455: I8. I 84. 
At a far later date Hamitic and Semitic tribes went southwestward toward northern Africa; the Semites making Arabia their home and center of radiation, the ancestors of the Hamitic people going farther and settling along the southern shore of the Mediterranean. These regions were highly favored during the moist and cool glacial period of the Pleistocene epoch, when large parts of the Sahara desert blossomed like a rose and supported a numerous population.

Not very much later, if at all, people began to follow the great river route up the valleys of the Euphrates and its branches into Asia Minor. This region also offered great advantages being a border land between northern and southern floræ, and offering many choice specimens of both, especially of fruits and nuts.

There was a third route which apparently became of importance only at a far later date in prehistoric times. It was the most northerly of all, and led westward around the northern end of the Caspian Sea, the foot-hills of the Caucasus, the northern shore of the Black Sea, and up the Danube Valley into the heart of Europe. It is now a broad zone of grassland or steppe, much like our western prairies. Whether it was forested during the height of the moist glacial period seems still uncertain. In that case the southern boundary line of the forest has retreated northward since that time. It was apparently the least attractive and last route to be followed. It is crossed by great rivers pouring southward from Russia into the Caspian and Black Seas, and every river valley formed a branch rouie. Hence Russia and Poland furnish many interesting remains of early prehistoric days while the story of later epochs is left in the remains of the Danube valley and its extensions northward.

The history of the development of pithecanthropus or some similar form into a human being worthy of the name is still shrouded in darkness which will only gradually be dispelled by farther discoveries in ill-explored western Asia and India. We pass from the Iranian plateau to the far better explored countries of Europe. 
Man arrived in Europe at some time during the glacial period or great Ice Age. ${ }^{5}$ In Pleistocene times a somewhat colder climate and high degree of humidity resulted in heavy snow-fall and the formation of great glaciers. These covered Scotland and Scandinavia, crowding well southward in England, and as far as the Harz mountains in Germany. The Alpine glaciers stretched northward leaving in central Europe only a narrow band of unglaciated territory.

The habitable portions of northern Europe at this time were France and southern England in the west, Russia in the east, and a narrow zone connecting the two. We remember that parts, at least, of the Sahara desert were well watered at this time, and that one or more land-bridges crossed the Mediterranean from south to north. Accordingly we find remains of African animals, e.g., rhinoceros and hippopotamus, mingling with those of northern forms. This leads us to suspect that the first men may have arrived in Europe by the same route.

We must not think of the long glacial period as one of uninterrupted cold and ice. We find it broken into a series of alternating glacial and interglacial epochs ending with the final glacial retreat. During the interglacial epochs the climate was usually mild, sometimes warmer than to-day. The arrival of man in northern Europe during the long and warm second interglacial epoch is proven by the discovery of a human jaw, near Heidelberg, and possibly by some very ancient fragments found in England. Of the life, habits and attainments of these earliest immigrant adventurers we know practically nothing.

During the third interglacial epoch Palæolithic man had evidently taken full possession of France and southern England, which then formed one province or region unbroken by the English Channel, which is of later origin. The remains of the Neanderthal race are found in other parts of Europe also and are probably still more widely spread.

What and how much did this primitive savage bring with

$$
\text { 5. } 24: 34.40 \text {. }
$$


him into Europe one or two hundred thousand years ago? First and most important he brought with him at least a crude form of family life. We can only glance at this attainment which, more than any other has revolutionized life. The reader is urged to study carefully the works of Fiske and Drummond on this subject.

The earliest mammals laid eggs but suckled their young. Even in marsupials, embryonic and fœtal life are short, but the young are born in a very incomplete stage and are carried for a time, nourished and protected in the marsupial pouch. In lower and smaller mammals the embryonic and fotal periods are still comparatively short. In larger and higher forms they are longer until in the human being they occupy nine months, and birth is followed by a steadily lengthening period of infancy when the young are defended and suckled by the mother. But in the highest forms of mammals, distinct in the anthropoid apes, less clear as we pass to lower forms, a third period of care and nurture is added, that of childhood. Thus the mother is burdened with the protection and care not merely of one or two young, but of a family of babies and children of different ages. ${ }^{6}$

In the case of the rodents all three periods are short and the small young can be hidden away. The young of the carnivora are fairly safe because few enemies dare approach the den where they are hidden. In ungulates the period of gestation is lengthened, but females and young are frequently or usually protected by the males of the herd. In the anthropoid apes the mother and young are sometimes protected by the arboreal life, or by the herding habit, or by both. The more powerful, venturesome male gorilla seems directly to guard and protect the female.

In all higher mammals the strain on the female is becoming unbearable and threatens her existence and thus racesuicide in a little different mode. There is only one way out. Some of the burden must be borne by the male. In

${ }^{8} \mathrm{R}$. 
rodents and many carnivora we find what may be called a maternal family, from which the male is excluded. From apes upward the genuine female-plus-male family is and must be on the increase.

Havelock Ellis says that Nature takes the female under her protection. ${ }^{7} \mathrm{He}$ seems to be right. But we might add that in mammals and many other forms the males, if of no use in protecting the female and young, are encouraged and stimulated to fight and kill each other off and thus save feeding useless mouths.

The form of the family is still uncertain. Promiscuity could hardly have been prevalent. Polygamy seems improbable under the conditions. The question is still under discussion. But Westermarck's plea for primitive monogamy is very convincing, and seems to be generally gaining acceptance. $^{8}$

The advantages of family life are so many and clear that we need and can notice only a very few of them. First, and not yet sufficiently emphasized, is the prolongation of immaturity and possibility of full development. Living anthropoids seem to mature about the age of six or eight years. Certain curious facts in the growth of the child lead us to suspect that our latest arboreal ancestors matured between seven and nine. Southern and primitive races still mature much earlier than those who have wandered into northern climates and been held back by its hardships.

The child matures slowly under the most favorable conditions for his physical and mental welfare. In our devotion to the study of heredity we have too much neglected to put proper emphasis on nurture, early environment. The soil and culture is almost as important as the seed in producing a good harvest. If the seed be a human germ-cell packed full of diverse mental possibilities and tendencies inherited from different strains and times, early nurture can accom- 
plish far more than we suspect, and even infantile neglect may be dangerous or fatal.

The child has the advantages of the experience of his parents and of past generations. The family must have been the cradle, if not the birthplace, of articulate speech which has so much broadened and clarified human thought and conceptions. In the close bond of family life mutual competition is replaced by mutual helpfulness. A large amount of energy, hitherto worse than wasted, is now utilized for the common good. The child by his dependence educates the parents even more than they educate him. The family is the smallest human unit; and it remains the unit of every larger stage of society. The fundamental and essential moral and intellectual training and progress are, and must always be, the work of the family. There will always be a sort of natural selection of families as well as of individuals. The most firmly united and best regulated families will in the end "outpopulate" inferior ones. With all these advantages and possibilities we can hardly fail to believe that the family, if not fully established in early palæolithic time, must have made rapid progress during the period.

Weak and defenceless man has survived amid larger, more powerful and better armed antagonists. He is now hunting them as well as they him. He has spread over the accessible world and made himself at home in all climates and conditions. His racial vitality is exceedingly high. He flourished and multiplied and spread even during the great ice-age which wrought wide extermination among the larger and higher mammals. His physical changes, except in length of leg and arm, have been very slight; yet he is evidently very adaptable as well as conservative. He has succeeded far better than we feared or dared to expect.

Let us glance at Neanderthal man in France during the warm Chellean period perhaps 100,000 years ago. ${ }^{9}$ He has all the human physical characteristics, though his forehead is

924. II7. 
decidedly retreating compared with that of later races. The changes from this time on are to be chiefly in the highest centers of the brain. He leads a hunting or collecting life. He has learned to chip a flint nodule into an almond shaped axe. The implements of his ancestors were probably mainly of wood and later of bone supplemented by an angular bit of rock. He now recognizes the superiority of flint, and the eoliths show us his long series of experiments in learning to flake and shape this useful but refractory material into a well-shaped, symmetrical tool. He makes a variety of tools, borers, scrapers, etc. Some day his descendants will make machines'.

He lived in open camps or villages during the warmer seasons or epochs; and took shelter in grottoes, under overhanging ledges or in mouths of caves when the cold returned; he is social. Here we find the bones of animals killed in the hunt and his implements mixed with the ashes of his fires.

Already or a little later he buried his dead, depositing with them parts of animals, apparently as food for a journey, axes, strings or masses of shells often brought from a considerable distance. ${ }^{10}$ The shells suggest that he had the savage love of adornment and of making himself conspicuous.

His care of the dead, his depositing in the grave food and choice possessions which he would gladly have kept, had he dared or wished to retain them, show that he has far outgrown the purely animal plane, mentally as well as physically. He believes that something of the dead outlasts the body, and might return to plague him. The fact of this cult is evident, its explanation is another matter. The growth of a belief and confidence in the existence of a spiritual world is the great thing.

He was beginning to think hard in a very dull stupid way about a great variety of matters. He returned from the hunt and lay before the fire. Hunger reminded him of the hard experiences of the day, its failures, blunders or wounds. $\mathrm{He}$ planned a new mode of attack for to-morrow. He dozed, and

${ }^{10}$ U. 8 I. 
his dreams being wiser than his thoughts, as seems often the case with primitive people, and sometimes with us, remained to goad and stir his mind. He awaked and gazed at the fire. It was a strange creature, devouring fuel, licking up the drops of water on the hearth, sending smoke and sparks skyward. He could not understand it; it teased, puzzled, and burned him.

Nature was full of enigmas, rain and hail, frost and ice, storm and lightning, sunshine and moon, accidents, diseases and death. There must be in it more of a something like his own inner self, which knew what he was doing and would punish him for certain acts and might help him, if he did others. He was not yet at home in it.

There were many things about which he could think, and probably talk; far more about which he could only wonder, for the world was full of mysteries. We have ceased to wonder, but the wise old Greeks knew that wonder was the mother of wisdom. And all the time in the harsh climate and home of fierce beasts Nature, "no fairy godmother," was always buffeting him and goading him to use his few wits to the utmost.

The hundred or more millennia of lower Palæolithic time rolled slowly away. Upper Palæolithic time covering the final retreat of the glaciers ushered in a new people and race which seems to have very largely replaced the Neanderthal folk. The new Cro-Magnon race was of a different physical and mental type and represented the noble savage. It is the wonder and admiration of all students of prehistory. They were tall, agile and vigorous, with high foreheads and strong features, and would have made fine models for the sculptors of to-day. ${ }^{11}$

Apparently they had entered Europe from the east, perhaps by the most northerly route. They produced a school of painters who covered the walls of caves with drawings and paintings representing animals with a lifelikeness and spirit not excelled by the most successful modern painters. Was

${ }^{11}$ I5. 272. 
the motive joy in the work? Probably to some extent, and this added to its beauty. But the painting was probably expected to give them some occult, magical power over the animals represented. They were a remarkable race with an equally remarkable art.

The Ice Age wore away. The tundra with its mosses and shrubs gave place to meadow and forest. The reindeer, the chief food of the Cro-Magnon hunters, went eastward and northward, and gave place to the forest stag. The hunters of the reindeer became fewer in number, and were succeeded by an inferior lot, apparently of fisherfolk along the streams. The long Palæolithic period had ended. 


\section{V \\ THE DAWN OF CIVILIZATION}

IGNS of the approach of Neolithic culture begin to appear in northern Europe about 8000 B. c.; possibly as early as 10,000 B. C. The important part of the period extended from about 6000 B.с., or a little earlier, until about 2500 B. C. At its very dawn this region enjoyed a very favorable and mild climate, and peoples poured northward and westward. The Mediterranean race spread from the sea from which it took its name into France and England. Broad-headed people appear in the highlands bordering the Rhine and Rhone and in the foot-hills of the Alps. Primitive tribes seep from Russia and Poland into Germany. Later a wave or tide of immigration seems to have poured up the Danube valley. All these people finally met and mingled in Central Europe. ${ }^{1}$

Very early we find them making pottery, and beginning to smooth or polish at least the edge of some of their stone axes. Generally they use less brittle material than flint. They seem to have experimented on various sorts of often rare rocks and minerals, and finally to have become quite expert practical mineralogists. They made baskets and nets, and learned to weave cloth of an excellent quality. ${ }^{2}$ They lived in half underground huts; later, as at Grosgartach and the Lake Dwellings, in very comfortable wooden houses. They raised wheat and barley and other grains. They had domesticated animals: dogs, sheep, cattle and swine. The savage has become civilized. If we could have spent a sum-

${ }^{1}$ 55. 36. г6г.

${ }^{2} 55$. I 3 I 
mer in a Swiss lake-dwelling, we should have found ourselves comparatively at home, with much to enjoy and admire.

During the later part of the period in northern and western Europe we find marked progress in the care of the dead. ${ }^{3}$ Dolmens consisting at first of five or six great stones are erected. In the doorway a hole is left open, apparently for the ingress and egress of the soul. The dead seem not to be feared, as they are by most very primitive peoples. The dolmens are enlarged and improved until they become dwelling places for a large company of the departed. Often they are surrounded by circles and radiating alignments of tall menhirs or standing-stones. At the very end of the period we find the dead deposited in small, completely subterranean vaults, or sometimes cremated; while the great stone circles are becoming temples rather than burial places. People are evidently thinking, clarifying and changing their views and opinions.

The key and explanation of all this progress seems to lie fundamentally in the introduction of agriculture and in improvement in cultivating the ground. This change took place earlier to the southward and eastward than in northern Europe. The beginning of the Neolithic period in Crete is set by Evans at about 12,000 в. с., de Morgan seems to have discovered still older Neolithic remains at Susa.

The rise of agriculture, the real basis of civilization, is a long process, we can sketch its history only in rude outline basing our description largely upon observation of savage or half-civilized tribes to-day. ${ }^{4}$

The savage is as much collector as hunter, accepting gladly whatever Nature gives him. The man hunts large game with good or bad success. Meanwhile his wife and children range and scour the surrounding area for berries and fruits, bulbs and tubers; frogs, fish, reptiles and large insects; all sorts of "greens," and whatever is edible. If she finds any ripened

355 . 123 .

${ }^{4} 56-58$.

55. I02. 223. 
grain or grass, she will surely beat out the seeds and carry them home with her. Here some of the seeds and smaller bulbs fall to the ground and are lost, but sprout and spring up in the rich soil around the hut. Some wise woman noticed this, pulled away some of the smothering weeds, and possibly loosened the soil with. her digging stick.

This is the beginning of the garden, far older than the farm, for ploughing has not yet been thought of, and hoeculture is woman's work. As population increased, and game became scarcer and warier, she had to furnish more and more of the food. Her labors were increased, but her importance and value in the family and community increased even more. Her knowledge of plants made her the first herbalist and botanist, the first physician; her knowledge of the virtues and harmful properties of certain roots and herbs gave her an uncanny power. She has founded agriculture and given it a high position and value.

The great danger is that the man and the children in hard seasons will eat up her scanty supply of seed grain or the young growing roots, and thus put an end to the experiment. There are signs that here the priest, medicine-man or shaman took her part, and laid the terrors of taboo, the forbidden thing, on all interference with her efforts. If the priests, the "see-ers" and only independent thinkers, and the women made alliance, the men could only yield. ${ }^{5}$ The garden grew apace. Before the end of the period the plough was introduced and pulled by cattle, held and guided by the man. Now the man is becoming a farmer. The economic importance of this revolution cannot be overestimated.

It had other deeper and higher influences and results. It slowly and gradually bound man to the soil, made him do many things which he preferred not to do. His reward and wealth were proportional to his patience, industry and skill. He is no longer foot-free to roam and wander as he will. He is being tamed and house- and home-broken. $\mathrm{He}$ ${ }^{5} 55$. 
begins to own more things than a few flint tools. He goes into partnership with Nature and is no longer a pauper, dependent on her rich or scanty gifts. $\mathrm{He}$ is gaining worth and dignity. He has been promoted, if he could appreciate it, to an entirely new grade and school of education.

He has a family and a home, and his home is in a neighborhood or village, and he cannot escape from it. In many things he must do as his neighbors do, talk and think like them. The erection of great stone monuments and the founding and maintaining of lake-dwellings are the work of men who have learned to coöperate in obedience to leaders and governors; and apparently the chief leaders were the priests and the old men of the tribe.

The Neolithic period was mainly one of peace, certainly not of the continual war and blood-shed which has been asserted of it. Weapons are few and scarce except among hunting tribes. It was a period of conservatism and yet of steady advance, for the two are not incompatible.

It seems safe to believe that in Neolithic tribes, like all peoples in a similar stage of development, the tribal conscience ruled supreme. The essential characteristic of the tribal conscience is the view that the whole tribe must accept the responsibility for offences of every individual member against individuals of other tribes or the gods. It is illustrated by the sin of Achan and rout of the Hebrews at $\mathrm{Ai}$; in the offence of Agamemnon against the priest of Apollo, punished by a pestilence sweeping through the Greek host; by the relations of the red men to the whites in America; and in a host of other cases showing its wide spread, if not universality, in a certain stage of social development.

If the tribe is responsible for the deeds of its individuals, it must and will control individual thought and action. Individual freedom is reduced to a minimum. The laws of taboo prescribed by the priests and the inviolability of ancient custom laid down by the old men constitute nearly the whole of the tribal code. It is like teaching an awkward squad of dull recruits to keep step or mark time. Neolithic man 
marched in lockstep. The "cake of custom" hardened over life. $^{6}$

All this had to be, and could not well be otherwise. If men and women were to live and walk together in communities larger than the single family, they must agree. Insubordination meant anarchy and social disintegration. Freedom of thought and action must wait until certain fundamentals and essentials had become thoroughly established. For thousands of years this steady and unremitting pressure was maintained and did its work. It resulted in tribal citizenship probably based on community of blood and descent; in social order, coöperation and harmony; in a sort of government. It tamed and civilized the savage and prepared him for a still higher stage.

The growth and development of social life is perhaps the most interesting fact in the history of the life of higher animals. The tendency to keep together is deep-rooted. We find insects and their larvæ, not to mention lower forms, moving in swarms, fish live and migrate in schools, partly because of the unequal distribution of food, though even here we suspect, or recognize a feeling of and for kind. A dim feeling of comfort or enjoyment in companionship has led to a gregarious life.

In birds and mammals the tendency to flock or herd together is a most important element in survival and progress. This is so wide-spread that solitary mammals, like some carnivora, seem to be the exception. Usually they group together for mutual aid and protection, as Kropotkin has shown. ${ }^{7}$ The survival value of this instinct can hardly be overestimated. It has double value as it continually replaces mutual competition, struggle and enmity, by mutual cooperation, and helpfulness, ending in friendship and love. It has been, perhaps, the strongest factor in humanizing man. He has discovered and formed larger and larger units of coöperation.

${ }^{6}$ 55. $2 \mathrm{II}$.

$7 \mathrm{~F}$. 
Mutual helpfulness replaces injurious competition first in the family, then gradually in neighborhood, village, clan and tribe. To-day we find great nations, whose vast energies and resources have led through fierce competition for trade and commerce to a long and annihilating war, struggling toward a world-order of peace and mutual respect and helpfulness permeating and uniting all the peoples of the globe. The cry of the age is: "We must get together." It is only the dawning vision of something long foreshadowed and sure to come.

The necessity of coöperation is rooted deep in human nature and structure. All Palæolithic men may have been able to sharpen a stick in the fire equally well, only a few could chip a symmetrical flint axe or shave a bone dagger, the joy of the hunter's heart and eye. Still fewer could engrave and ornament it. Division of labor was only just beginning to enable every man to find his place and do with joy the work which he was fitted to do best. It shows far more marked results before the end of the Neolithic era. We find centers of mining and manufacture of flint implements; work shops of pottery, weaving and other handicrafts; manufacture of jewelry from amber and other substances. This means mutual interdependence between more and more distant areas, trade-routes arise and bring new patterns, influences and ideas.

Coöperation was fostered or compelled by the introduction of agriculture and increase of population. The agriculturist lives in a village and has neighbors. They work together to rear compact lake-villages or great stone monuments and circles. They must keep step with one another; they cannot walk together unless they agree.

In these villages folk-ways arise and become habits. Habits crystallize in customs; and the "cake of cutsom" hardens around the individual and the social unit. ${ }^{8}$ The custom satisfies some need or meets some emergency. It springs at first from a dim feeling rather than from clear in- 
tellectual device. It is accepted on probation and is at first liable to change. It is tested by a process of trial and error; and what is at first mainly a dim faith is corrected and justified or condemned by experience. Huxley said he believed in justification not by faith but by experiment. The savage, an investor in "futures" like us all, believed in testing by experiment step by step the promising suggestions of his faith. He accepted the provisional hypothesis which worked.

This is only one side of a sublime process of human growth and development, probably it is only the lower rough surface of the fabric. The greatest asset of weak, defenceless, curious, prying man was his needs; just as his greatest possession was his possibilities, his "futures," his Castles in Spain. He has long been prying into surrounding nature, now he is beginning to turn his attention inward on himself. Our "benighted ancestor" made full use of his discoveries in both fields. We will return to this subject in our next chapter.

Out of all this defencelessness and feeling of need, prying curiosity, social mode and form of life and its necessary implications, out of a dim faith and endless experiment and broadening and deepening experience, rose a body of ways and customs which set in tribal law and tribal conscience. Some things may be done; many must not be done under any provocation or circumstance. They are taboos, forbidden; the individual dare not even think of rebelling. Viewed from this standpoint the resulting system of Mores becomes a code of morals or ethics. It was hardly the outgrowth of careful thought; largely, as to-day, not so much a matter of logic as of a certain good taste or instinct developed almost unconsciously out of millennia of experience. However we may regard man's attainments at this time as small or large, and I believe that we have generally decidedly understimated them, they were certainly full of possibility and promise.

The development of primitive religion is still a field for surmise rather than sure and definite statement. ${ }^{9}$ Through

9 63-7I. 
needs and fears, wonder, observation and hard experience man came to believe in beings or forces, call them spirits if you will, who kept watch of him and punished severely, the forbidden act of trespass; some of whom might be willing to help him while others could be placated. Cult and ritual for appeasing the angry and helping the kindly spirits grew very similarly to the growth of Mores and morals. Morals and religion advanced together, man coöperating with his gods. We may call them demons, if we will leave out the necessary implication of evil and malice usually implied in this word. Their character like that of man varied from extremes of evil to those of preponderating good.

Professor Murray has well pictured the primitive ritual and belief of the ancient Greeks before the arrival of Achæans or genuine Hellenes. These ancient Pelasgi, if we may call them so, worshipped spirits or demons in indefinitely vast numbers but with no individual names; represented, if at all, by emblems or symbols very rarely in human bodily form. Of these demons of calamity, disease, death, madness; of fertility and other forms of beneficence, there were "thousands upon thousands, from whom man can never escape or hide." 10

Men had become tillers of the ground. Their life was still precarious. "Their food depended on the crops of one tiny plot of ground. All the while they knew almost nothing of the real causes that made crops succeed or fail. They only felt sure it was a matter of pollution, or unexpiated defilement. It is this state of things that explains the curious cruelty of agricultural works, which like most cruelty had its roots in terror, terror of the breach of taboo - the Forbidden Thing."

Neolithic man, with his new discoveries and industries, had given new hostages to fortune, and a new and wider scope of application to the old doctrine of taboo and of tribal responsibility. This strengthened the hold of the priest or magician on the hopes, fears, and faith of his people. The law is going deeper as well as wider. There arises an individual 
feeling of pollution and of the need of expiation which will blaze out in the oldest Greek tragedies as almost a veritable sense of sin. We might almost say that a sense of morality toward the spirit world is now appearing in a religion previously almost or quite unmoral. We may easily overestimate the extent and power of the change, but we can hardly be mistaken in recognizing its dawn and the vast germinal possibilities of this dim feeling or conception.

In agriculture and throughout nature, seedtime was followed by harvest, fall, and winter's gloom and death. Then in the next spring there was a return, a rebirth or a resurrection. If the seed failed to come up, if the blade withered or was blighted, it was because the vegetation spirit or demon had failed to reappear or had been reborn weak or sickly, and all this because some one had broken taboo, had touched the forbidden thing. This must be prevented at all cost, they must help the spirit. Hence there must be every year a time of purification, or renovation, when the old garments and utensils and everything which could carry the pollution of death were cast off or cleansed. ${ }^{11}$

All these conclusions, and some others of equal importance to which we will return later, are expressed or symbolized in the great Dromena, festivals, mysteries, or whatever you may call these rites of pre-Homeric Greece. Then for a time, they are partially, though never totally, eclipsed by the brilliant beauty of the Olympian religion with its glorious temples, statues, and other works of art.

There was vastly more vitality in the ancient crude symbols and chaos of conceptions than in the ordered and artistic Olympian hierarchy with its marvellous renresentations of the gods in human or superhuman form and beauty. ${ }^{12}$ Even its art and literature could not save it. It had lost its mysticism. The old Neolithic religion, handed down by peasants and artisans reoccupied the field, transformed sometimes almost beyond recognition like the Ugly Duckling of the fairy tale.

1166

$1264-66$ 
It returned triumphant through sheer power of unlimited vitality and adaptability. Plato draws his finest illustrations from its mysteries, out of which, also, the Greek drama arose. Paul quotes from them or from a similar stratum of belief.

Some of the many sources of its vitality are obvious. It was rooted in the firm conviction of the existence of a spiritual world toward and into which its every rootlet was forcing its way and from which it drew nourishment and power. We might better change the illustration and say that it was slowly developing a spiritual eye which peered into a higher world and developed in keenness and clearness of vision in response to the higher pulsations. By patient experiment and experience, which produced a hope that could not make ashamed and a faith in which hope and experiment combined, it was feeling its way into spiritual knowledge. It knew nothing of practical science or of material cause and effect. But its world pulsated with the universal life. It recognized the law of forbidden things and the sure penalty of lawbreaking. It had a tribal conscience and recognized the need of purification. It had the promise, at least, of individual conscience and consciousness of $\sin$.

Its symbol was the mystery which lifted only a corner of the veil and left an abundant opportunity for wonder, imagination, thought, and mysticism, which was entirely lacking in the perfect statue and the finished creed. It made man, through its sympathetic magic, a coworker with his divinities or demons in gaining the answer to an intense desire or prayer acted by all the members of the community with all their united might, the utterance of his whole being and life, instead of expressed merely in words. Such a system or chaos overflows with sublime possibilities.

The introduction of agriculture had produced another most important change in religious views and ritual. In tillage the earth brought forth and gave birth to the crops which furnished their chief food supply, and probably, in their view, to animals and men also; just as the human mother gives birth to the child. Hence there was a wide-spread belief in 
a cult of an earth divinity, of course female, or in a goddess or demon of fertility. She is sometimes or usually accompanied by a male partner, companion or son, but he occupies a lower place.

This cult of the goddess seems to have been a marked feature of Neolithic religion. ${ }^{13}$ We find it in the remains of the Minoan period in Crete: Isis and her companion god Osiris were prominent in Egypt. The cult was wide-spread throughout Asia Minor: Diana, or better Artemis of the Ephesians, $\mathrm{Ma}$ in Anatolia, the great goddess of the Hittites, are a few examples. Pumpelly found a female idol at Anau. The cult dots, if it does not cover, the migration route. In Greece we find Demeter, and in "Pelasgic Athens" Athena always held the highest place. We find deeply buried traces of a similar goddess cult in most parts of northern Europe. The cult of the goddess probably belongs to the close of the Neolithic period, as the belief in innumerable nameless demons represents the early Neolithic or Palæolithic stage. Laugh conceitedly, if you can and will, at these "superstitions" of our benighted ancestors. They were permeated with an intense vitality. They are still crude in form and will be refashioned and better expressed as man grows in wisdom and reverence. The substance is already present; the elements and possibilities of a grand religion. It is a growth of hundreds of millennia. You can change or modify or reëxpress it. You cannot uproot it. It has become imbedded in the fibers of man's brain, a part of his life-blood.

Plutarch seems to have been nearer the truth than some modern observers and students when he wrote "Pass over the earth, you may discover cities without walls, without literature, without monarchs, without palaces and wealth; where the theater and school are unknown; but no man ever saw a city without temples and gods, where prayers and oaths and oracles and sacrifices were not used for obtaining pardon or averting evil."

13 59. 70. Chap. V.

55. 218 . 


\section{VI \\ THE RISE OF PERSONALITY}

T EOLITHIC civilization had apparently sprung up in more or less compact and isolated tribes of agriculturists, where life was simple and quiet, and where there was generally comparative equality of possession and uniformity of life. Here it lasted longest. Its typical development went on somewhat aside from the great routes of trade and migration, as in large parts of France and England, in Scandinavia and the extensions of the Danube valley. It rose and culminated far earlier in Asia than in Europe.

But even in Europe increase of wealth and difference of power and condition, trade, commerce and the spread of ideas, the mingling of peoples and cultures in its central valley, above all the increase and spread of knowledge, discovery and initiative, were continually undermining tribal custom and control. It was fast becoming outgrown.

The same changes had gone faster and farther in the great thoroughfare of migration and trade running westward along the northern face of the Caucasus Mountains and shores of the Caspian and Black Seas from Central Asia into the grasslands of southern Russia. ${ }^{1}$ Here isolation was impossible. Here we find fortified villages when they had hardly appeared in northern Europe. Agriculture flourished, but much of the country was even better fitted to the raising of cattle and sheep. Here apparently the horse had been domesticated not far from 2000 B. с. The population was mixed and diversified.

Along the southern borders of this great fertile and popu-

18I. Chap. IX. 
lous region were cities in close trade communication with Crete and later with Greece. The most western of these tradingposts was Troy. The Black Sea and its rivers were ancient trade-routes carrying northward the wares and ideas of more favored and advanced southern lands. Southwestern Russia and the Balkans came very early under the sway of Mediterranean stimuli and influences.

Here agriculture and cattle-raising sprang up early. Civilization progressed rapidly, and the cake of custom had less opportunity to harden. There was far less uniformity, isolation was impossible, tribal characteristics were less marked. There were wealth and inequality of possession. Change was comparatively rapid. Individual leadership and initiative were at a premium. It was a land of restless adventurers compared with the more stolid peasants of northern Europe.

Here was the ancient home of the Aryans; extending far to the eastward, its northern extent is still uncertain. A common language was used all over its wide unbroken area, doubtless with many dialects. It had to express the needs and thoughts of many conditions and cultures, was used in trade and commerce. Those who spoke it were in communication with many men, cities and lands, it was in a sense cosmopolitan, flexible and adaptable. Before the end of Neolithic times its sphere of influence had probably reached far beyond the borders of the old Aryan hameland.

Not very far from 2000 B. C., the people were swarming out from their old home. The eastern Aryans went into Persia and on into India. Aryan names soon appear in Asia Minor. The western Aryans invaded Greece and spread over Europe. We have an excellent picture of the Achæan leaders in Homer's chieftains. They were fighters and adventurers, boastful and loud mouthed, running over with animal life and spirits, great talkers and story-tellers not overhampered by respect for truth, good mixers and magnetic leaders. They hated toil and work. These adventurers were freebooters; open, generous, frank, kindly when not opposed, rough and cruel as a parcel of schoolboys when angered. 
Their coming among the Neolithic settlements of Greece must have been like the arrival of a party of cowboys in a community of pacificists. They "painted the town red." Resistance was hopeless, submission usually quick. They probably exacted from the people not very much more of toil and labor than had been demanded before, and were excellent watchdogs. Their heroes married the daughters of the rulers of the land and became kings. The changes were quick, thorough and not altogether for the worse.

These roving bands of emigrants from the Aryan homeland were composed mostly of the young and vigorous. They had left behind them the old men, the lawgivers of the tribe, and guardians of its traditions. They had broken and cast off all the old tribal fetters and restraints and enjoyed their freedom to the full. Their leader was a young adventurous fighter like themselves. The source of his authority was his frowess and success as champion and ability to lead. Dour gigantic Ajax, swift and athletic Achilles, and shrewd resourceful Ulysses listen patiently to wise wordy old Nestor, and do as they will. Their only law was the word of the leader, and his power depended on his right arm and the loyalty of his followers.

The city states, which sprang up somewhat later all over Greece, prospered or failed largely according to the power, ability and wisdom of the individual irresponsible ruler. $\mathrm{He}$ is the outstanding feature and characteristic of the Bronze and early Iron Ages, and loyalty to him is the chief virtue of his followers. Tribal rule and tribal conscience have seemingly disappeared, vanished with an outgrown past.

They had left the mother-goddess behind in the homeland, very possibly even there her cult and worship had long since declined. Their conception of divinity was quite naturally a war god hurling thunderbolts or wielding a magic hammer. His moral endowments were of secondary importance. The goddess of the conquered land seems often to have been married to their own god. They were exceedingly liberal in matters of theology, and freely admitted new divinities to 
their Olympian council. The result was the glorious and scandalous Olympian religion. In the end the religion of the ancient mysteries proved to have more, vitality and adequacy. It survived in the writings of poets and philosophers, while the Olympian religion waned.

Greek civilization was undoubtedly a blend of Achæan and ancient autocthonous Pelasgic elements; and it is uncertain which contribution was the larger. Is it mere coincidence that the city-state called Pelasgic Athens always maintaining the cult of a goddess Athena, struggling toward democracy, a city unsung and hardly named by Homer, was the chief seat and center of the highest, finest and best thought and life of Greece?

A very similar conquest on a much larger scale was being carried on in Northern Europe by the Celts resembling the Achæans in temper and spirit as if they were twin-brothers. They seem to have swarmed out still earlier and in greater numbers. Before the close of the Neolithic period we find signs of their culture in the Rhine valley. During the Bronze Age they seem to have overwhelmed England and northern France. They conquered Bohemia and parts of southern Germany and went down into northern Italy. In the early Iron Age they raided still farther, but were pushed back finally by the Romans in the south and the Teutons in the north and ground between the upper and the nether mill-stones.

The story of the dawn of history seems to be mainly a chronicle of similar migrations, raids, invasions and conquests: every new invader crowding the preceding ruling race down into the mass of common people. This results in new blends and variations which were later to express themselves in national characteristics. But the process was slow, and the subjected people were usually left for a long time unchanged in their deeper character by the new super-imposed stratum. ${ }^{2}$

In every case there resulted a ruling class and a subject, half-enslaved or reasant mass holding obstinately to their beliefs, customs and Mores over against those of their con-

2 82. 83. 40. 
querors. The two may gradually mingle and even fuse, or they may long remain as distinct as oil and water. The conservative mass has on its side the weight of numbers, of more rapid increase, of endurance and stability. In the end it will maintain itself and win recognition. This struggle of the mass of the people for its place and rights, and toward a real and workable democracy seems to be the important feature of political history.

The individual played a very subordinate part in the rise of Neolithic culture and civilization. It was a tribal movement in lock-step and there could be no straggling from the ranks. There was uniformity and monotony. Different tribes differed comparatively little from one another. It was a stage of civilizing the savage by compelling him to till the ground, common to all civilized peoples, though different tribal units may have advanced with different degrees of rapidity according to innate endowment and surrounding conditions. It was a great tidal wave of human advance impelled by world forces, and creeping slowly and relentlessly with a broad and comparatively even front.

In the Bronze and earlier Iron Ages there was great diversity. Every people or city-state tried its own peculiar experiment under its own leader. Egypt, Greece, different parts of Europe, go every one its own way to a certain extent; and near neighbors may differ markedly. We are living not in the age of the "totem," but of the "hero ": ${ }^{3}$ not of reactionary old men but of revolutionary, adventurous young leaders who care little for the past, and rule under new conditions. The experiment is largely one devised or shaped by the individual leader, and its trend and results are less the expression of deep and universal human tendencies, and more that of his individual thought and will. The advance or deterioration depends largely upon him and the weight of responsibility begins to make itself felt. The advance, if it be so, begins to show the variety and uncertainties of modern so-called progress. It is more rapid but less sure in its form and direction. 
All the time the great problems of life are increasing in number and complexity until they seem insoluble.

We lose our way in this strife and turmoil which seems to have no direction or meaning. But one fact of vast importance stands out clear in all the welter and confusion: and that is the rise of something far higher than mere individuality, namely personality. Do you ask "What is personality?" It cannot be laid bare by the scalpel, discovered by the microscope, or weighed in any physical balance. It is more than a bundle of tropisms or instincts or even a seeing mind. The vocabulary of the zoölogist seems inadequate to express it fully, if at all. It seems quite new and unexpected, but it has been coming ever since Palæolithic days,-or perhaps far earlier.

It is suggested in Henley's lines:

"It matters not how straight the gate, How charged with punishments the scroll, I am the master of my fate:

I am the captain of my soul." 4

The ship is heavily freighted, rolls clumsily in a stormy sea, and often refuses to answer the helm. The crew, and he is captain and crew at the same time, is always ready to mutiny and requires a firm hand and stout heart. He is an adventurer in uncharted waters, sailing to a remote harbor. Will he make port?

$\mathrm{He}$ is responsible to himself and to other persons for the success of his voyage. If he fails by his own fault, he feels remorse, not merely regret but a new feeling of which he cannot rid himself. $\mathrm{He}$ has rights to maintain and duties to perform. He has a certain, if limited, power of choice and hence of freedom. Above all he must guide and control himself lest he lose his position and become slave to some lower self, for an enslaved person is an absurd misnomer, a contra-

4 84. 56. 
diction of terms. The depths of his own being astonish or awe him. All this he knows, and can forget or neglect.

Most of all, he is still very incompletely personalized. $\mathrm{He}$ is on the way to a fully developed personality. As ever before his possibilities may be infinite, but his realized attainments on this new plane of life are few and small. Man is still coming, he has not yet arrived,- even in these great United States of America.

Said Huxley: "Man now stands as on a mountain-top far above the level of his humble fellows, and transfigured from his grosser nature by reflecting here and there a ray from the infinite source of truth. And thoughtful man once escaped from the blinding influences of tradition and prejudice will find in the lowly stock whence man has sprung the best evidence of the splendor of his capacities, and will discern in his long progress through the past a reasonable ground of faith in his attainment of a nobler future." 5

The air on the mountain-top is rarefied and the light dazzling; the language of its inhabitants sounds somewhat foreign to us. We leave man as a person to and with the psychologist and philosopher, and return to our "humble fellows" in the valley, where we are more at home.

5 D. 


\section{VII}

\section{THE LOGIC OF EVOLUTION}

T $\mathrm{E}$ cannot fail to notice that life is continually rising from lower to higher planes, and that it shows new powers and new meaning from stage to stage. The upward road seems to pass from table-land to table-land, and the transition to be a sudden and rapid ascent. This is probably not the case. We might compare these transitions to the changes at the melting and boiling points in a mass of ice. The rise of temperature may be continuous, but the form and behavior of the mass becomes entirely different and new at certain critical points.

The progress from a bacterium to an amœba and thence to a group of cells is great, but we cannot dwell upon it. The second stage is that of the sacklike cœlenterate, whose cells are arranged in two layers. It has a digestive cavity, gains a fair amount of food, uses comparatively little for fuel, hence reproduces rapidly. All the surplus goes to the reproductive organs. There are nervous and muscular tissues, and some feeling and locomotion. But these functions play a very small part in the life of the animal. Temporary survival of the individual, existence and continuance of the species is practically all it asks.

The flat worm shows us a transition to something higher. It still lives to eat and reproduce. The digestive system has improved, the reproductive organs are exceedingly highly developed and very complex. But muscles, or rather masses of muscular fibrils, nerves and nerve-centers and sense organs have appeared. The animal is moving and feeling its way.

Certain results of this change are apparent in the highest 
worms, the annelids. Here well marked muscular fibrils line the body-wall, sheathe the intestine and enclose the perivisceral cavity. The digestive system is fast attaining its definite general form, though it will improve greatly in details. The reproductive system receives a smaller surplus and is simpler. Circulatory, excretory and respiratory organs have arisen in service of muscle. Sensory organs pay, and are continually stimulated as the animal glides through the water. They and the chief ganglion are improving rapidly. We have been speaking of nerves and muscles, we ought to speak of one neuro-muscular system. Every added muscular fiber demands the addition of a nerve-fibril, and of one or more nerve-cells in the nervous arc. Every improvement of the sense-organs demands and stimulates the rise of new cells in what is fast becoming a brain. Muscle is the leading partner and drags or pushes all the organs to a higher stage.

In some or many annelids we find two or more claw-like horny teeth at the mouth. These are very efficient weapons. The period of universal peace between leading forms is past, the gladiatorial struggle has begun, a quite new phase of life. Survival can continue only through exercise of the muscles, strength and agility, a keen lookout of the sense-organs and guidance of the developing brain. The annelid represents the culmination of millions of years of unceasing experiments of our progressive vermian ancestors; the aberrant forms mark a few of the partial successes. The failures, and they seem almost innumerable, have disappeared and left no trace.

Certain points of attachment of muscular fibrils, or the whole skin, secrete a solid support or defence; a skeleton appears. The external protective skeleton of mollusks was vastly productive of ease, comfort, safety, placid enjoyment survival and success, of all that makes life worth living with stagnation "thrown in." The external, chiefly locomotive, skeleton of arthropods was simple, easy to build, admirably suited to small animals, light, resistent, useful in a variety of ways. Arthropods were precocious and their development was rapid. 
The internal, almost purely locomotive skeleton of vertebrates was exceedingly difficult and slow of development. It required a long series of none too successful experiments before it was completely attained. It resulted in a marvellously adapted support for the well molded, powerful muscles of large animals, giving swiftness, agility, and tireless locomotion. Jaws and teeth furnish unequaled weapons. The sense organs are large and keen, adequate to great speed over a wide range. The nerve-cells of many segments are drawn into the capacious brain. They have fulfilled the promises of annelids.

The large size of the vertebrate is correlated with long life, with varied but oft-repeated experiences of the individual. He forms instincts; he has at least the promise of intelligence. The lower vertebrate is mainly a locomotive engine of offensive warfare, his world is an arena of fighting, devouring brutes, a not altogether pleasant spectacle. But we find plenty of movement and numberless experiments.

The amphibian has crawled out on land; a poor, clumsy crawling animal, whose short feeble legs can scarcely lift it from the ground. But it walks, and every step is a series of muscular movements demanding close and accurate control in special nerve-centers, while the direction of locomotion is determined by the brain in response to the reports of the higher sense-organs. There is some variety in the use of the two pair of appendages. Somehow the brain, the great central switchboard of the nervous system, manages to distribute these stimuli to the proper muscles in adequate intensity. Its problems and responsibilities are steadily increasing. The appendages lengthen and strengthen, become adapted to locomotion on land or in the air; the internal locomotive skeleton has been practically completed, its possibilities pretty well exhausted; reptiles, birds and nammals have appeared.

Reptiles tried a vast series of experiments in framing a vertebrate body. Some are of huge bulk, others small. The snakes gave up the appendages, returned to the primitive writhing method of locomotion and carried it practically to perfec- 
tion. Some reptiles swam with paddles, others flew with batlike wings. Some ran on four legs or strode on two, using the front pair somewhat like hands. They became at home on land, in water, and in the air. They conquered and possessed the world partly by brute force, partly by speed and agility. They showed the possibilities of a marvellously developed muscular system guided by a very economically constructed brain.

From flat worms upward progress has been focused chiefly on the muscular system. Its development has dragged with or after it that of all the other systems, even of nerves, senseorgans and brain. Keen sense-organs have been a great asset but mainly as a part of the steering apparatus. Thus far the race has been to the swift and the battle to the strong, as was to be expected. The bird carried the tendency to its logical conclusion. It became a flying-machine; and this aërial adaptation has left its stamp on every organ of the body. In swiftness of locomotion, in keenness of sense especially of sight, the hawks and carnivorous birds hold the record.

It is a somewhat disappointing story. Millions of years of painful struggle and combat, and infinite experiment, and the result is something less efficient than an automobile with eyes instead of lamps or an aëroplane careering through the air. It reads like Falstaff's bill at the inn. We say: "One halfpenny worth of bread to this intolerable deal of sack!" If movement was all we wanted, there was plenty in the delirious electrons.

There is nothing particularly striking or interesting in primitive mammals. In breadth of experiment, in adaptation and general development they seem to lag behind birds and reptiles. They are certainly not precocious. Their energy of evolution seems to be turned aside, drawn off, in some direction hard to follow. They have the advantage over reptiles of maintaining a constant comparatively high temperature of the body. This stimulated the activity and development of the organs somewhat in proportion to the complexity and instability of their chemical composition, especially of the proto- 
plasmic nerve-centers and glands. But birds have a still higher temperature.

We have already seen that the development of the neuromuscular system, the lengthening of the embryonic period and accompanying increase in size of the eggs have greatly diminished their number and made the care of eggs and young of an importance which cannot be overestimated. The bird deposits its eggs in a nest; in all but the very lowest mammals the mother carries them in her body.

The period of gestation and infancy is continually lengthening and the strain on the female increases correspondingly. ${ }^{1}$ Something pointing toward or approaching family life appears far down in the history of placental mammals. The chief instincts and the dawning intelligence seem to center around the young. The plays of lower mammals educate both mother and offspring.

The earliest of even the placental mammals were apparently comparatively stupid. But care of young and the continual harrying by their reptilian overlords was a school of severe but steady and sure training. Says Lull of the "archaic" mammals: "Their brain was singularly old-fashioned, generally small, but always relatively undeveloped in comparison with that of modernized mammals of equivalent bulk, especially in the part wherein the intelligence lay. Hence it is not surprising that the career of these forms was brief and that with rare exceptions they have suffered racial death and vanished as utterly as did the dinosaurs before them." 2

Brain and intelligence are rising to leadership in the neuromuscular partnership. The dominance of muscular bulk, arrangement and power, even of weapons of offence or defence, is beginning to pass away. Everything points toward a new and thorough revolution. All our "modernized" mammals possess some or considerable intelligence and learn by experience. They are educable.

\footnotetext{
$1 \mathrm{R}$.

2 H. 549.
} 
But steady and rapid development of brain and thought is emphasized and made supreme in one line, that of the primates. We need not repeat their history. They were apparently defeated forms kept in order and confined to their arboreal refuge by stronger competitors. The effects of this training, the use of hand and eye in arboreal life, have already been emphasized; they appear in the systems of manual training in our schools to-day. The millennia of primate training in the school of arboreal life were not wasted.

The comparatively weak and defenceless anthropoid descended from the trees, and pitted his few and feeble wits against brute strength and cosmic force. The result of the struggle was man. His weakness compelled him to be watchful and wary, cautious, prying, curious. It compelled him to eke out his feeble muscles by the discovery, manufacture and use of tools. Physically he is tough, enduring, adaptable; a cosmopolitan species; mentally he is growing keen, observing, thoughtful. There is something human about him, but something more is needed to make him genuine man.

"Nature," says Osborn, "deals in transitions rather than in sharp lines." We studied the rise of the discovery and recognition of spirit, and hence of religion, in Palæolithic man; of the rapid rise of morals to supremacy in Neolithic days; and of personality in the Bronze epoch. The exact date is of small importance. Those powers became prominent at those times. A more careful and accurate study would place their emergence earlier; their "embryonic development" was vastly more ancient. The fact to be emchasized is that it is just those qualities which have raised him to the mountain top far above his humble fellows," have transfigured him; that he is incurably moral and religious. If he neglects or stifles them, he degenerates into something worse than a beast. To call some men beasts is to slander lower animals.

Morals arose under the stimulus of social environment and neighborly pressure: religion through the dread and fear of invisible buffeting fowers. But in describing the school we must not forget the pupil. There can be no genuine morality 
and religion except of persons, possessing a certain amount of freedom of choice and hence of responsibility, feeling within themselves the categorical imperative of duty, and responding to a "power, not ourselves, which makes for righteousness." Could man have ever discovered morals and religion, if he had not already felt within himself the stirrings of personality however dimly recognized? The present high-water mark of evolution is a very incomplete personality with its immeasurable possibilities and promises.

The stages in human evolution are well marked and distinct. The first is the protozoan stage of single cells or colonies with no tissues or organs. Second is the almost vegetative stage when digestion and reproduction are the dominant functions. The third is the muscular or locomotive stage when strength, swiftness and agility, keen sense-organs and weapons of offence and defence seem to be the goal of evolution. Fourth comes the dominance of keenness of perception and the rise of intelligence. This, however, ought properly to be considered as a transition between the dominance of brute force and weapons and the complete rule of mind expressed in personality.

Every stage ushers in something new and unexpected. Jelly-fish, reptile or bird, and man live very different lives, every one in a world of its own. Is it any exaggeration to speak of "creative evolution"? Yet the new stage was somehow and somewhere, concealed in the old; was prophesied or foreshadowed by it, is in a sense its only logical outcome. It is just what we ought to have foreseen and expected.

The stages of digestion, of locomotion and of personality may be compared to three great dynasties in the history of the animal kingdom. Every function or power holds the throne as long as it is capable of improvement more rapid and profitable than that of any other system. A digestive system always remains comparatively simple; a sack or tube with a certain number of glands is all that is needed. Its use is limited, its possibilities are soon exhausted.

Muscle and skeleton are far more complex, capable of great 
variety in amount, form, structure and grouping. Their capacities for experiment and improvement are many, great and not easily exhausted. The dynasty held the throne for ages. The era of personality has only begun. We know not what we shall be. But the possibilities of mental evolution are unlimited; they may be infinite. The dynasty of personality is secure and permanent. No other system or power in the body can dispute its place and right.

Every lower dynasty needed, stimulated, and thus ushered in the reign of the next higher power; and then became subservient to it. ${ }^{3}$ Every higher power begins its career as servant of the lower; then evolution becomes revolution, and the yoke of the lower is thrown off. The reign and dominance of the higher does not stop or hamper the development of the lower function; it maintains and improves it, while it controls and may limit it. The digestive system attains its highest development not during its period of supremacy, but in its service of muscle and brain.

The same is true of the muscles. They are not as bulky and powerful in man as in many lower animals. But they are numerous, complex and varied. Of course, all our muscles have their place and use. But man's chief advantage lies not in the size of his heavy fundamental muscles of back and shoulder or thigh, but in the fine accessory muscles of his fingers guided by the exceedingly complex accessory braincenters. These contribute the fine complex movements. An ape would make hard work of playing a violin. It is hardly accurate to speak of "arrest of the body" in man, though its day of supremacy is past. It becomes continually finer, better adapted to higher uses and nobler ends discovered by the thinking brain.

Yet, outside of certain centers in the brain, the organ of mind, the bodily changes between higher apes and man are few and hardly noticeable. Physically man remains one cosmopolitan species under all stimuli to variation. His intelligence has increased by leaps and bounds. Whether his 
moral development has kept pace with his intellectual is, we hope, an open question.

As every higher power was needed for the complete use and development of the lower, the sequence of dynasties was quite natural and logical. The higher ought and had to arise except where there was arrest or failure of development. The only logical goal of even zoöphytic development was mind, and the worm foreshadowed the coming of man. All these powers are potentially in the amœba, and his potentialities, not his attainments, are his best assets and highest values. Their worth can be determined only when they are unfolded or actually realized. The lower stage is incomplete, conceals far more than it reveals. It can be appreciated and properly valued only in the light of the higher, which reveals its meaning and to which it is a stepping-stone. "Origins prove nothing," as William James said. The finished statue, not the rough-hewn block tells the story.

The lower organ or function once firmly established and supreme in the body does not readily and easily yield its control and gracefully abdicate in favor of the higher power of greater possibilities. There is always a struggle for supremacy between the lower and older, and the younger and better. The final revolution succeeds only in the face of bitter opposition. The struggle is anything but brief, we always ought to carry all the good, we must carry much that must be outgrown, into the future. The old dynasty must not be banished as a whole but assimilated in due subordination to the higher. Here is the rub. Hence many or most fail altogether to attempt the revolution; never break loose from the old, outworn, motives, habits and modes of life; remain permanently on the lower plane.

Man and animals can at least attempt to reverse this natural and logical sequence of dominant functions, and exploit in the service of the lower whatever of the higher has been attained by their progressive ancestors. The free-moving form can become sessile or parasitic. This spells degeneration of all organs, except the reproductive, or more usually 
extinction; the sacrifice of the higher with little permanent gain and usually loss to the lower. In higher forms of animals, degeneration, as a rule, does not result in existence in meaner form or on a lower plane, but comparatively quick extinction.

If we are convinced that this sequence of dominant functions is a fact, that always in the successive ancestral stages leading from amoba to man, higher and higher functions have risen to dominance; that attempts to reverse the sequence have ended in failure and, as a rule, in extinction; we shall be convinced also that future man will be more and more completely controlled by the highest powers and ends toward which this sequence points. We shall recognize that our business is the enthronement of rightness and righteous personality and that all else is of secondary importance; that we live not in a gladiatorial or primarily economic, but in a moral and religious world befitting man. Rightness of will and effort is the provisional goal of human effort and progress. This involves not so much the remaking of surrounding conditions as the remaking of man himself.

But man is not pure spirit, and the past lives in him. The tiger refuses to die, and the ape is immortal. His higher powers of memory, association and imagination, and the burning focus of attention, strengthen the hold of appetites and gratifications and future rewards and punishments are as if nonexistent. Every upward step in attainment of comfort in art and in science, every new discovery opens new fields not of carefree enjoyment but of struggle.

It is a struggle not so much for existence as for life. Apeman descended from the trees to give battle to the hostile powers of the animal kingdom and the natural world. $\mathrm{He}$ has overcome his competitors and bends the forces of nature to his will. Now he is his own worst enemy. The king is in rebellion against the king, and abdication is impossible save by suicide. Rex regis rebellis.

We have noticed that higher mammals are educable and glanced at the graded school of training of primates and man. 
Is the chief characteristic of protoplasm its educability? Huxley has told us in a remarkably brilliant and sane essay that Nature is the great educator, and framed her bill of compulsory education long before man arrived on the globe. Life and experience are the great teachers, and the world is the school of this grand system from which we are never graduated. He says: "That man, I think, has had a liberal education who has been so trained in youth that his body is the willing servant of his will, and does with ease and pleasure all the work that, as a mechanism, it is capable of; whose intellect is a clear cold logic engine with all its parts of equal strength and in smooth working order, ready like a steam engine to be turned to any kind of work, and spin the gossamers as well as forge the anchors of the mind; whose mind is stored with a knowledge of the great and fundamental truths of Nature and of the laws of her operations; one who, no stunted ascetic, is full of life and fire, but whose passions are trained to come to heel by a vigorous will, the servant of a tender conscience; who has learned to love all beauty, whether of Nature or of art, to hate all vileness, and to respect others as himself. Such a man, and no other, I conceive, has had a liberal education, for he is as completely as a man can be in harmony with Nature. He will make the best of her, and she of him. They will get on together rarely, she as his ever beneficent mother, he as her mouth-piece, her conscious self, her minister and interpreter. Education has two great ends to which everything else must be subordinated. The one of these is to increase knowledge; the other is to develop the love of right and the hatred of wrong. With wisdom and uprightness a nation can make its way worthily, and beauty will follow in the footsteps of the two, even if she be not specially invited." 4

Future generations will care little about the number of our automobiles, aeroplanes and telephones or of stories in our sky-scrapers, for the size of our cities, ships and fortunes, the number of horse-power developed from our rivers and

$4 \mathrm{E}$. 
coal-fields. They will regard with some wonder and pity the crudeness of our laws and institutions. They will smile at our systems of science and philsophy, as we smile at those of past centuries. They will ask: "What permanent contribution did your age and nation make to human life and progress, and to the development of a higher and better personality and humanity?" Our answer to this question will fix our place in history. By it we shall be judged, and justified or condemned. Shall we be remembered with little Judea and Greece or be forgotten gladly like great Assyria and other exploiters? 


\section{VIII}

\section{NATURE AND MAN}

$\mathrm{P}$

ERSONALITY marks the present high-water mark of a flood of life sweeping steadily onward. Man has not yet arrived, very possibly he never will. $\mathrm{He}$ is coming. Man represents the apical bud, the growing point, of the luxuriantly branching tree of animal life. But most of its branches bend downward, a host have died.

The meaning of evolution is to be sought in the direction of its tendencies expressed and partially realized in its highest forms, not in bacterium or protozoan. "Origins prove nothing." Says Bergson: "A perfect definition applies only to a completed reality; now vital properties are never completely realized, though always on the way to become so. They are not so much states as tendencies." 1 Life is dynamic, not static, it is always changing, "doing things."

We have paid no attention to the vegetable world or to the inorganic realm of chemistry and physics. In the great universe, man is quantitively hardly more than an atom, a "thinking reed." His strength has always grown by hard exercise and daily use just because of his weakness and defencelessness. We live in a universe of whirling, seething forces; at the same time universe of order and law. Human life has a quality value and worth distinct from and superior to them all. It stands out sharply outlined against the background of Nature. Life is a guiding, directing, controlling power. Where is the throne or hiding-place of this elusive force?

We begin with the amœba. Where is the seat and what 1 I : I3. 
the nature of its control of its parts? What determines "diminution of surface-tension" or the contractility of the ectoplasm in the protrusion of a pseudopodium; and what reverses the process in its withdrawal? What is "responsible" for the coöperation of fibers, granules and other particles in its momentary life? Control is a fact; but we cannot explain it.

Why do the separated cells of a pulverized and sifted calcsponge recombine and rearrange themselves in the old shape and form? There is energy of guidance and control hovering over and immanent in the multitude of cells. More we dare not say. ${ }^{2}$

In the development and growth of the bones of mammals, in our thigh-bone for instance, what controls and directs the work of the myriad of osteoblasts and osteoclasts continually adding material to the ends of the terminal knobs or condyles, and gnawing it away along their lower surface, changing what had been a knob into a part of the shaft? The rival hosts coöperate in fashioning and lengthening the bone as the artist shapes a model, adding clay here, scraping it off there. Such miracles are being performed in and around us every moment. We are too busy to notice them, much more to ever think of them.

What combines the working of all the organs of the body, every one doing its own share and amount of the work? Seek its seat in the nervous system, if you will. But as Bergson says: "A nervous system with neurones placed end to end in such a wise that, at the extremity of each, manifold ways open in which manifold questions present themselves is a veritable reservoir of indetermination." Where is the operator for the great telephonic switch-board? "The rôle of life is to insert some indetermination into matter." 3 We are searching for a seat of control.

These strange substances, hormones, produced at one point, set free under some stimulus, traversing the body like tor-

200.90.

3 I. 126. 
pedoes, exploding only in some particular, often remote tissue, and producing a needed result, only add to our amazed perplexity instead of relieving it. Mr. Darwin once said that the sight of a peacock's tail made him sick. Most of us are less sensitive.

An army is far more than a mob of individuals; it is individuals plus, or in a very real sense multiplied by, discipline, organization, command, authority. A republic is not merely square miles of territory and millions of inhabitants; it is these and organization through and by a central government. The state may be an abstraction but it is very real one, against which it is fatal to rebel. It can condemn the rebel; say to him: go and be hanged, and he straightway mounts the scaffold. Otherwise it is a poor contemptible state. Analcgies may suggest, though they prove nothing.

Said Whitman in a very interesting article on the "Inadequacy of the Cell-Theory": "That organization precedes cellformation and regulates it, rather than the reverse, is a conclusion that forces itself upon us from many sides." 4 Years ago Huxley wrote in his vigorous English: "They (the cells) are no more the producers of the vital phenomena than the shells scattered along the sea-beach are the instruments by which the gravitative force of the moon acts upon the ocean. Like these, the cells mark only where the vital tides have been, and how they have acted "- possibly a somewhat extreme statement of a truth demanding emphasis.

The development of every fertilized germ-cell into an adult, introduces the same problem of directivity. Says Wilson: "What lies beyond our reach at present, as Driesch has very ably urged, is to explain the orderly rhythm of development - the coördinary power that guides development to its predestined end. We are logically compelled to refer the power to the inherent organization of the germ, but we neither know nor can conceive what that organization is." 5 Again, "The cells are local centers of a formative power pervading the

4 I03.

5 I04:59. and 432. 
growing mass as a whole, and the physiological autonomy of the cells falls into the background."

If we were not altogether wrong in the conclusion of our last chapter that the whole process of evolution bears all the marks of a certain natural logic, if there is clearly direction in the current of life, there must be here also some guiding, controlling energy above or behind the competing individuals and groups. A river forces its way through barriers and seems to make its own channel. Yet the lines of the river system are determined in the end by the natural physical and geological features of its drainage-basin. How far is the course of the current of evolution determined or modified by surrounding conditions, by Nature, how far by inherent tendencies?

The courses of the different balls in a charge of grapeshot fired from a cannon are evidently due to two sets of forces - 1. their initial velocity and the direction of aim, 2. the deflecting power of resisting objects or forces - or the different balls might roll rapidly down a steep mountain side. In the first case velocity and direction of course would be determined largely by initial impulse; in the last by the attraction of the earth and by the inequalities of its surface. If we lay great weight on initial tendencies, inherent in the germ, we shall lay less stress on the guidance and control of Natural Selection; if the directive tendency of the germ is small or weak, the burden and "responsibility" of natural selection must increase in similar proportion.

Years ago the botanist Nägeli propounded an ingenious and elaborate theory of evolution, as dependent almost entirely on inherent initial tendency. Natural selection played a very subordinate part. His theory seems one-sided.

Let us glance at the view of an extreme, perhaps somewhat old-fashioned neo-Darwinian. The seat and center of the controlling energy lies in the continuous chain of germ-cells stretching from protozoan to man; always buried and shielded deep in the body of the parent beyond the reach of external agencies or the habits and acts of their bearers, except in so 
far as these may effect the general health and nourishment of the whole germ-cell or of some of its particles in a general way. Variation comes about through the shuffling and dealing of the granules in connection with the maturing and conjugation of the germ-cells. Its direction is not affected by environment or by habits and behavior of the parent.

The variations which actually arise may be entirely undetermined, perhaps in all directions equally. Of these radiating individuals natural selection allows some to live and kills off the rest, and thus determines the direction of evolution of the species.

If the variation in such a series of generations is mostly along one line or in only a few directions, it is guided more or mostly by the tendencies of the germ-cells, and the work of natural selection is correspondingly lightened.

Says the neo-Lamarckian: "The animal body is one and control is one pervading the body and all its cells, even germ-cells must be to some extent, at least, included under this control. The germ-cells cannot have that independent and exclusive autonomy postulated by the neo-Darwinian. Bodily variations cannot go on without producing corresponding changes in the germ-cells, in some degree." How this energy reaches the germ-cells is no clearer than how osteoblasts and osteoclasts are controlled, or how the arrangement of cells in an embryo is brought about. The fact of control is a different matter from the explanation of how it is brought about.

Both schools are beginning to see that each holds certain points which the other would like to see fully proven; each has its difficulties and limitations. A compromise or higher synthesis will probably replace both. Both agree that the direction of the individual life experiment is determined very largely by heredity, the energy inherent in the germ-cell. Neither will deny that the final control of the grand strategy of the evolution of life as a whole and its direction is in large part the result of the process of natural selection. For this in the end controls the survival and permanence of cer- 
tain lines of development while it weeds out and discards a host of others.

Here nature has the last word. Man can become her partner, and she will make him ruler over many things; but he is responsible to her and to God for his use of the power delegated to him. She demands a strict accounting, and every day is a day of judgment. She is a stern mistress, a hypercalvinist.

We are all experimenters. Nature sets the test, lays down the rules, assigns the marks, awards the prize and there seems to be no appeal. Our bodily and mental structure and functioning, our laws, our deepest convictions, our social ways, our moral codes and ends are all being slowly but surely tested in her great experimental laboratory of life. Much of our discomfort and pain is due to our neglect and reckless disregard or criminal ignorance of what really constitutes conformity to Nature's ways and laws; it is her premonitory warning of her threatened fatal box on the ear.

In one word, man, good and bad and imperfect as he is, is the result of a process of selection of those living beings who are best conformed to, and embody and express in life, the laws of nature. Huxley's liberally educated man " is as completely as a man can be in harmony with her. He will make the best of her and she of him. They will get on together rarely, she as his ever beneficent mother, he as her mouthpiece, her conscious self and interpreter."

Speaking of "natural knowledge" he goes on to say: "There are blind leaders of the blind, and not a few of them, who can see nothing in the bountiful mother of humanity but a sort of comfort grinding machine. According to them, the improvement of natural knowledge always has been, and always must be, synonymous with no more than the improvement of the material resources and the increase of the gratifications of men. Natural knowledge is, in their eyes, no real mother of mankind, bringing them up with kindness, and, if need be, with sternness in the way they should go, and instructing them in all things needful for their welfare, but 
a sort of fairy-godmother, ready to furnish her pets with shoes of swiftness, swords of sharpness, and omnipotent Aladdin's lamps, so that they may have telegraphs to Saturn, and see the other side of the moon, and thank God they are better than their benighted ancestors." ${ }^{6}$

If Huxley were alive to-day, I believe that he would speak in still more vigorous English, but with less urbanity. Man is still in his nonage, scarcely more than a child. Occidental man, most of all here in America, is a spoiled child.

In our use of the gifts of a bountiful nature, we resemble a parcel of spoiled and ill-mannered children who have broken into their mother's well-stocked preserve closet where she has put aside a rich supply of good things against a day of thanksgiving and a winter of need. They have stuffed themselves, destroyed what they could not devour, wasted nearly all, quarreled with one another, and have left ruin behind them. They are bitter in their out-cries against any and every neighbour who refuses to allow them similarly to misuse his property.

They will emerge dirty, nauseated, ill-tempered, an unpleasant sight and neighborhood nuisance. They all unite in blaming their mother for not having secured the door and brought them up better. They need a sound spanking, a cold bath, a large dose of physic, and school early to-morrow morning.

Is not this a just picture of the ways and doings of our generation which culminated in the war? We wonder that our children give so little heed to our wisdom, preaching and teaching. Yet, here we are talking about Nature whom we have abused, and who might well and justly vent her wrath on us. Perhaps it is as well to make her defendant and to act as judge and jury before we appear at her bar.

Is Nature good or bad, moral, unmoral, or immoral? It is hard to say. We look at man, her child, "her conscious self, mouthpiece and interpreter." Is he good or bad? He seems to be both; sometimes rising to sublime heights of hero-

${ }^{6} \mathrm{E}$. 
ism, sometimes sinking into a bottomless pit of meanness, stupidity, folly and sin. Goodness and badness seem to form strata or streaks in his character, both alternately coming to the surface. He is always putting down or yielding to mutiny or rebellion waged by his worse self. Here we call it the problem of moral evil, against which generations of the most profound thinkers have bruised head and heart. If man spends much of his time and most of his energy in such battles, need we be surprised if Nature also shows some conflicting features and forces? We may yet discover some rays of light on this dark question, but they will be feeble and dim.

If you wish a clear view of Nature in her fairer aspects, read Huxley's essays on "Liberal Education" and "Natural Knowledge." I know of no more unsparing judgment of her shortcomings and perversity than his "Evolution and Ethics." I cannot pretend to harmonize or judge between the two presentations. Both are somewhat one-sided and extreme; each rests on undeniable facts; they supplement each other. The reader must judge for himself.

But even if we accept the severest arraignment of Nature and the catalogue of her manifold sins and transgressions, a word may still be said in her defence; perhaps her child, man still in his nonage, is at least partly responsible for the sins which he lays at her door. Is he not somewhat spoiled, illtempered and irresponsible? Let us accept squarely and honestly our just share of the blame, and manfully take our punishment and medicine.

Does Nature teach ruthless competition and treading down of others? Does not the social or gregarious life of nearly all birds and mammals equally teach coöperation and mutual helpfulness? ${ }^{7}$ Perhaps even we are far enough advanced to have outgrown certain methods of action and training unavoidable and even helpful on a lower stage, but now an abuse. Perhaps the outgrowing of certain brutal or childish things is what we are here for, and what Nature demands of her "con- 
scious self." Above all let us always seek her last ruling and interpretation of her laws.

When all has been said there remains much for man to do. Many of her methods can be improved. There is much which must be opposed or curbed. If the desert is to blossom as the rose, many thorns and briers must be uprooted from the soil. We must also remember that she is continually stimulating our growth in strength by compelling us to wrestle with or against her; and the game is often rough.

We must understand her and her ways; and without sympathy understanding is impossible. We may learn to marvel at her beauty, even if we cannot always and altogether admire her character. We can appreciate Nature only as we know and understand ourselves; and most of us are too busy or idle to devote much time to the study of either. Somehow we must live and get on with her for, to mis-quote Hiawatha:

"Though he bend her, he obeys her, Though he draw her, yet he follows."

We have said that good and bad in man lie in alternating layers or streaks; there is much good in the worst, too much of bad in the best. This is partly due to the presence of outworn tendencies which ought to have been outgrown, partly to lack of health and vigor, partly to weakness and ignorance, partly to sheer perversity and original or acquired sin.

Much of it springs from a still deeper root. Man is an exceedingly complex being. He is like a craftsman who has so many tools that most of them grow rusty and dull for lack of use.

We will take only one illustration as sample. Our mind manifests itself in intelligence, feeling and will. In the healthy mind these are all highly and symmetrically developed, but this is a rare case. We find cold-blooded intellectualists, who feel little and accomplish less. Some of them are "seeing cripples." We find weak, "sentimentalists," oil-films on shallow pools; also obstinately self-willed people of narrow 
intellect and no feeling, completely blind. Head and heart rarely balance.

This is due partly to heredity increased by early nurture or neglect and the environment of youth and maturity, partly to our own negligence or perversity. The result is lack of symmetry, balance and control; of Engkrateia, inward strength.

Burn sulphur, niter and charcoal separately and you get mainly a bad odor. Combine them thoroughly in proper proportion, put them in a gun-barrel, ram down a bullet; then take care how you aim. Something will happen.

We very rarely see the result of high, symmetrical, complete development of all the powers of the mind in a single individual, like Socrates or Lincoln. There is nothing about them which sticks out conspicuously and attracts our notice; their greatness is concealed by their symmetry. Long after their death we begin to appreciate them. They form what Heine has called "the apostolic succession of great souls, the only people in the world who ever see anything as it is," and who understand its meaning. These men show us what man can be and will be. They live, and are more than irrefutable arguments for immortality: they are samples and illustrations of it. They cannot die, though they may belong to the noble army of martyrs. Nature will some day produce a race of such men, if there is any logic in evolution. She will not be balked.

We are all more or less crippled by our weakest spot, our undeveloped or disused powers. They avenge themselves on us for our neglect by remaining mainly to plague us. But some of us reserve for ourselves an even worse fate. Said Zarathustra to the cripples on the bridge who begged him to heal them: "It is the smallest thing to me, since I have been amongst men, to see one person lacking an eye, another an ear, and a third a leg; and that others have lost the tongue or the nose or the head."

"I see and have seen worse things, and divers things so hideous that I should neither like to speak of all matters, nor 
even keep silent about some of them: namely men who lack everything, except that they have too much of one thing men who are nothing more than a big eye or a big mouth, or a big belly, or something else big,-_reversed cripples I call such men."

"And - I could not trust mine eyes, but looked again and again, and said at last 'That is an ear! An ear as big as a man!' I looked still more attentively - and actually there did move under the ear something that was pitiably small and poor and slim. And in truth this immense ear was perched on a small thin stalk - the stalk, however, was a man. A person putting a glass to his eyes could even recognize further a small envious countenance, and also that a bloated soullet dangled at the stalk. The people told me, however, that the big ear was not only a man, but a great man, a genius. But I never believed the people when they spake of great men."

"Verily, my friends, I walk amongst men as amongst the fragments and limbs of human beings! A seer, a purposer, a creator, a future itself, and a bridge to the future - and alas! also, as it were, a cripple on this bridge: all that is Zarathustra."

"Not the height, it is the declivity that is terrible!" 8

Man is the blind giant of the will guided, but not completely or directly controlled, by the seeing cripple of the intellect perched upon his shoulder. In partnership they will go far and accomplish much. But do not most of us go through life scarred, maimed, crippled or "reversed cripples"? Man will surely come; he is coming, he has certainly not yet arrived.

The evolution of man resolves itself finally into a series of discoveries, of his finding more and more in a Nature which is trebly or tenfold masked, and of which we still know very little. The whole process is a tendency or urge toward higher and finer powers still only crudely expressed even by man.

For millions of years on this old earth Nature busied her-

8 IO2. 
self with chemical and physical problems. Then life and consciousness appeared in microscopic particles asking at first only existence. The whole trend of Nature's forces seemed to be toward a being which could digest and reproduce. All else seems subsidiary or by-product.

Gradually the world becomes an arena of struggling, fighting brutes developing a tough, powerful body with keen sense organs and sharp weapons. The forces of Nature seem to combine in one grand resultant, compelling the highest animals to follow this line of march, every other road leads to degeneration or extinction.

Man became a thoroughly social being living in families, villages and tribes, where mutual competition is replaced by mutual helpfulness and affection. $\mathrm{He}$ is in a fair way to become a highly intelligent, rational, moral and religious, spiritual being. This is a revolution; old things are passing away, all things are becoming new; but the change is very recent, the revolution has only begun. Its completion is the only logical, rational, natural result of the whole history of animal life; otherwise life is a "story told by an idiot, full of sound and fury, signifying nothing;" a "march from the inane to the inane."

Nature, still maintaining physical power and vigor, has unmasked herself, and shows a very stout countenance set on righteousness. But man is still in a very immature nonage and learns exceedingly slowly. He halts between two courses or worlds, an outgrown past and an unattained future. In developing personality Nature had to loosen the curb of her rein and leave man to learn by hard experience how to control himself. He learns very slowly. His hardest work is to put down his own mutiny and rebellion against his better self.

Nature has set her vigorous, energetic, highly endowed child free to choose and act for himself, has made him her partner, in a sense her vice-regent; has given him all things freely to use and enjoy. Like many other heirs to wealth for which they have not toiled, man turns ungratefully, abuses and ex- 
ploits the free gifts of Nature, and would make her his slave; an exceedingly dangerous experiment.

She has not abrogated her laws of the great game. Heredity has insured that the best attainments of his ancestors shall go to the child, also some of his weaknesses. If a man persists in squandering this entailed estate, he, not Nature, is responsible for the loss; and his children may justly curse him. Nature is not to blame, and the law of heredity is on the whole and in the long run beneficent.

Natural selection for which, as for heredity, Nature is responsible, has certainly resulted in a marvellous line of sure and comparatively steady progress. It sifts and selects unsparingly and with ever higher standards for survival. It has always demanded the seemingly impossible; it will probably continue to do so. After a period of prolonged prosperity, when survival has been comparatively easy and variation wide, there must always follow a period of the severest selection of a saving remnant. We can only gird our loins to meet the test or go down before it.

We may well face the fact that, as Huxley has said, "the avoidance of pain and discomfort is no proper object of life." Nature's school and training is not for carpet-knights. We may yet discover that life is not a scheme for the greatest possible ease and luxury, but an adventure in endurance resulting in experience, wisdom, and a well-founded hope, a Marathon race. This doctrine is exceedingly old-fashioned, old as the life which began before the everlasting hills were born.

The frontiersman of progress does not expect all the luxuries of an old artificial civilization. His reward is an abounding life overflowing with the glow of health, and a youthful civilization close to Nature. On him she smiles. They "get on rarely together," and he falls in love with her in spite of her imperfections and waywardness. She is good enough for him.

I hold no brief for Nature. She can defend herself. But her highest ways are past finding out, and we cannot search 
for them too carefully. We are to blame for many of the worst cruelties and crimes imputed to her. Let us be fair and just toward her. We may find kindness and divine beauty behind her masks and disguises. 


\section{MAN AND ENVIRONMENT}

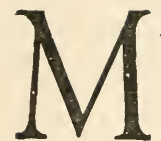

AN is Nature's mouthpiece and interpreter, the conscious expression of what is best in her, as well as of some which is not so good and must be outgrown. Nature is very slowly and patiently educating, guiding and moulding him as she has all his humbler ancestors. The individual, the species, or the larger group which fails to obey her laws and conform to her ways is slowly but surely weeded out. Only those which meet the requirements of her tests survive. If we neglect or resist her training we go down and out. The penalty of disobedience and non-conformity is death.

Conformity means literally taking the form of the impress of environment, like wax under the pressure of the seal or clay in the hands of the potter. Every part of our body bears the impress and stamp of the conditions under which it arose. Our cells are bathed in lymph like unicellular organisms in a primeval ocean. Our trunk was constructed by writhing worms. Our backbone in its various forms during successive stages of development points to changing conditions and habits of ancient vertebrate life. Legs and arms, jointed appendages, tell of emergence on land; every bone and joint is the solution of problems of physics and engineering. Our hands were shaped and finished in an arboreal gymnasium; our feet modified to suit life on the ground. Our nervous system tells the same story. Man is a walking museum of palæontology, every part bearing the impress of conditions at the time of its origin. The same may be said of every animal. Says Weissman: "When you take away all the ad- 
aptations from a whale, there is not much left." The story of evolution is a history of successful adaptations.

In every age and stage of our evolution some organ has had its special time for rapid change and improvement. Then the pressure or urge passes over to some other part, as we have seen in our study of the sequence of dominant functions. The essential features of the organ now set and become relatively fixed; all further changes are slight. Nearly all the organs of the human body have acquired fairly definite form and structure, and have changed but slightly during the last million years. Changes now are mostly limited to the "silent areas " of the cerebral cortex. There is a time for everything and "opportunity knocks but once." Yet it is all one process, "the history of the ever-advancing victory of spirit over matter," as von Baer said.

We have spoken of conformity to environment as if it were merely a stamp impressed upon receptive and passive material. This is not correct. The adaptation consists in a reaction of the living being, stimulated by external forces. The reaction or response to the stimulus differs according to the character of the responding animal or man and hence may vary greatly. I may give the same kick to a stone, a sheep or a bull-dog; the response will be quite different. The more highly developed and complex the animal, the more varied and less predictable its response. Sloth, squirrel and ape are all adapted to an arboreal environment, but they have reacted very differently; all three have conformed but in different ways and to different degrees, the sloth apparently the most completely of all.

There is such a thing as over-adaptation where the animal or man has so completely adapted itself to one set of conditions that change and readaptation to a new environment is no longer possible. If its environment changes, as it always does, or if it is compelled to seek a new environment, it is at a disadvantage and probably disappears. Large size usually shows that conditions in a certain age and place have been favorable and adaptation complete. If climate and food-supply 
change, the largest forms usually suffer first and most severely. This has been an important factor in the extinction of many dominant groups; so, probably, of reptiles. Through overspecialization and adaptation to one part or aspect of nature, they have lost touch and conformity with the whole. This means ruin. ${ }^{1}$

Surroundings crowd, urge, stimulate, draw or attract in varying degrees and in different directions according to the animal on which they act. The resulting reaction or response depends upon both variables.

We may say that in higher animals and man, environment is very largely a matter of relation of the individual to his surroundings. If I am entirely outside of any relation, direct or indirect, to a certain object in my surroundings, it can form no part of my environment in any proper sense of the word. Here three elements, all variable, are concerned: objects and forces of the external world, man or animal, and the relation between the two. Hence we all live in one world but every man has or forms, to a certain extent, his own environment. Under similar surroundings, different men have different environments. From one almost compelling set of surroundings Judas went down to Gehenna, and Peter went up to the throne. Each had his own environment and went to his own place. Surroundings and environment are anything but synonymous words; very much, if not all, hinges on the relation.

Some elements appear fairly constant in all environments, e.g., air, water, light. We are just beginning to appreciate the importance of climate, differing indeed, in different regions and changing from time to time. One element is continually shifting, due to the rise of new forms of life and the disappearance of old ones. The rise of sharks compelled all weaker, perhaps hitherto dominant forms to seek refuge. The same may be said of reptiles, whose disappearance gave mammals a wider opportunity. Man of the species Simia de-

1 H. II3. I77. 228.

I9. 
structor has wrought much ruin in the world, as Homo sapiens he may help to restore and transfigure it. The relation of animal to animal and of man to man, a relation continually changing, is the most important element in biological history.

The first step in conformity is discovery. ${ }^{2}$ When we discover an object, we bring it into relation to our sense-organs or mind. We focus our attention upon it and discover new possible relations which may satisfy some pressing need. Then we proceed to experiment, and frame and establish some new relation; and we may call this an invention.

The amœba is always groping in the surrounding water. It is remarkable how early the animal began to develop senseorgans. The higher worms possess them all, though crude and incompletely developed. The ear starts as an organ for feeling vibrations in the water, and ends as an open doorway for the entrance of all the highest and finest, as well as lower, sentiments and appeals. We can take heed how and what we hear. The eye, at first a mere light-perceiving speck, aids in perceiving the direction of the source of light, and ends by forming images of surrounding objects. Imagine the furor in some learned society of annelids, when Alciope announced and maintained that he could see and distinguish the form of an object almost an inch distant. And these sense-organs stimulate and develop the brain, until it - or the immanent mind - becomes a sense-organ itself discovering values and ideals, beauty, truth, goodness and God; all of which he has discovered, none of which he could make. They make him, if he so wills or allows. These are all in the margin of his environment as soon as discovered. What and how close his relation is to be to any or all of these, seems to be left to him. We are apt to forget how large a part discovery plays in evolution. Man combines and relates the results of his discoveries; he makes comparatively little. All his so-called laws are expressions or descriptions of objects and relations which he has discovered. ${ }^{3}$ 
This sensitiveness to and discovery of new objects and conditions gave nature a new opening of attack in higher animals and most of all in man; it opened new environments in a world of ancient objects and forces. Environment is evidently something very different from a mass of surroundings, all lumped together; it is not simply a resultant of forces; it is to every man a new relation to a new combination.

Surroundings are mostly the raw material out of which every living being consciously or unconsciously, with or without understanding, will or purpose, selećts, or accepts certain portions and out of these constructs its own environment according to its own inherited structure and tendencies or acquired character. This is his unique experiment by which he stands or falls.

A man may be known and measured by his environment, for it is "the company he keeps." His position in the hierarchy of life may be fairly accurately measured by it. It broadens, deepens and towers in proportion to his development. The lower animal changes his environment by his powers of locomotion, moving from dangerous to advantageous surroundings; man accomplishes much the same result by shifting the focal point of his attention.

Certain parts of our environment seem irrevocably fixed for at least some of us, so that we cannot escape them. So climate. The slum or a city palace is forced upon many children so that they cannot escape. Neither is desirable; good and brave men have risen from both. Early parental influence and education may be, and often are, fatal to full and normal development. But these can and should be improved if as many as possible are to be fitted to survive; man has changed all these, and can and will improve them. Man migrated northward into Europe. Its cold harsh climate had direct invigorating effects. Its indirect effects were still more important. He needed shelter; he discovered it in the mouth of a cave or under an over-hanging cliff; then he built a hut. $\mathrm{He}$ was chilled, and discovered fire and learned to use it. $\mathrm{He}$ covered and protected himself with skins of animals. He 
was weak and defenceless, he used a pebble or sharp stone as a weapon, and learned to shape an axe and other tools. Population increased and game became scarce; he became an agriculturist. Society arose and new needs with it. There is interdependence and mutual aid and coöperation. Man has become a moral being; and has discovered a spiritual world which alone can satisfy his spiritual needs.

Man's greatest, most valuable and essential assets and possession are probably not his attainments, for these are small; not his Castles in Spain, for these are remote; they are his ever-present bitter needs. ${ }^{4}$. From them spring discovery, invention, progress. As soon as these are satisfied, we die. It is as well we should. Nature does not spoil her children as fond parents do.

Man selected certain materials furnished by Nature and has given them a form answering to his needs. From a pauper dependent on her gifts he has become a partner, possibly a leading partner, with her. Here and there he is trying to make her his servant. He has framed a new environment, built up between himself and her as a defence against her slings and arrows, and as a means of farther utilization of her bountiful gifts. This environment is to some small extent natural, but very largely artificial, the work of his hands. He, not Nature, has framed it; it is his experiment. Without it, sometimes with it, he remains a savage. It increases in amount, complexity, advantages, opportunities and dangers with the progress of civilization.

But while he has been fashioning and building it, and become more and more dependent upon it, it has steadily changed and molded him for better and worse. He adds arts and sciences unattainable without it. But the artificial environment tends to master and enslave him. He craves not only the supply of his natural, but of a host of artificial needs, some of which are or may be excellent. He craves luxuries satisfying every appetite, desire and whim; life has become strangely, intolerably dull, he must have artificial stimulants and all 
kinds of amusements. All these tyrannize over him. $\mathrm{He}$ is becoming the slave of things.

Nature is idealized as a fairy godmother, or valued as a mass of exploitable material. Science is encouraged not so much as a means of truth as a provider of comforts and luxuries, and an ally in despoiling nature. He has barred out nature so far as he can; becomes weak and unhealthy in mind and body. Complete conformity to artificial environment and repletion have cost him his vigor and powers of endurance. He glories in his over-specialization and seems in a fair way to become a "reversed cripple." Men have invented and made - we might almost say created - vast military, political or economic machines and trusted in them. The machine catches and crushes them in its wheels and then breaks down because of its weight and complexity. Is not this the history of every ancient "successful" civilization? Why should we be an exception?

Can we fail to notice the same tendency in all social life with its opportunities for mutual help and improvement, and wealth of enjoyment, its training in manners, which are or should be a branch of morals; its correction of our individual one-sidedness and weaknesses and egoism; its power of public opinion; its conventions, fashions, tyranny, futility and emptiness? We make the political machine, it rules us, and we worship it. This looks like either fetichism or "graft," or both.

In all such cases we allow the "cake of custom" to thicken and harden around us and tearfully mourn that we cannot break it. ${ }^{5}$ The confession. if true, explains, justifies and seals our doom.

"We wrestle in our present state

With bonds ourselves have forged and call it fate."

There is, as Huxley has well said, a natural and an artificial system of education. Our artificial system should prepare us to receive gladly and use wisely the education of nature and life. Is it suited to teach men and women how to live, to

${ }^{5}$ T. 201. 
meet life's opportunities and emergencies, to fit as many as possible to survive? Does it also tend toward over-specialization and narrow, one-sided development? Is it broad and human, or almost entirely professional or vocational in its aims and results? Is it producing strong and wise leaders and training us to be their loyal followers? We will leave all these questions to those who have specialized in education.

Our artificial social environment is of almost compelling importance. We cannot escape it; how can we best use its advantages and opportunities and avoid its evils? Let us hold fast to the fact that our environment consists not altogether in surrounding objects and conditions, but also, and even more, in our relation to these. The same object at different times varies greatly in importance to me, according to my moods and its nearness or remoteness. Yet that which is near at hand is usually not appreciated, and the obvious, the axiomatic, in life, is always forgotten or neglected.

Let us glance at one or two illustrations. Two men find themselves in a company of average men and women. One of them is sympathetic, hearty, overflowing with health and humor; the other more intellectual, critical, somewhat inclined to dyspepsia. The first finds the company of his fellows intelligent, kindly, agreeable; the second finds them just the opposite. Each reports honestly and truthfully his experience and observation. Each has seen and drawn out a different side of the same people, and has contributed of his own. From the same company each has framed his own social environment. Each has selected, expected, found attracted and encouraged that which he was fitted to call out. The material was the same, the use different.

One new relation may change a man's whole life and thought. I was walking the street one dark, chilly, winter day. A young fellow called out to me cheerily: "Good morning. A fine day!" I wondered what ailed him. A moment later a friend explained the mystery, telling me that the young man had just brought a trying pursuit and courtship to a happy ending. Nothing had changed in or about the boy or girl. They 
were just what they were twenty-four hours earlier. But one new relation had been formed. He would not have been so gay, or the sky so bright, if she had promised and honestly tried to be a sister to him. We trust the new relation resulted in permanent mutual encouragement and uplift.

The content of the book is insignificant to the page in a library. Another has few books, and little time for reading, yet lives in and by them. One man is lifted, thrilled, and strengthened by music, painting, the beauty of smiling valley, of clouds and sunsets or the grandeur of the mountains; another, living in their midst, is practically unaffected by them. They form the surroundings of both, the environment of one.

Two men read a page of poetry or science. One is inspired by the "splendor of truth," which was Plato's definition of beauty; the other remains cold and dead. The passage is really as foreign to him as if written in an unknown tongue. No man can be a hero to his valet, or anybody else, if heroism is foreign to the spectator's environment. The environment of a reversed cripple can hardly be other than hell or a "fool's paradise."

Improvement of surroundings seems to mean removal of barriers to progress and increase of opportunity. But these do not reach the root of the difficulty; this lies in the individual will and purpose. To treat only surroundings or even the intellect for weakness or perversity of will is much like prescribing external applications for deep-seated disease.

This fact has been emphasized by many or all great thinkers. Plato said that many men must be improved before they can be educated. Another great thinker has said, "The law is weak." Possibly the best any of us can do is to see to it that we encourage and call out the best that is in our neighbors, not the worst; and contribute to the common stock only the best that is in us, keeping the rest for home consumption. Most of us can still improve our minds. If you would know how, ask the psychologist. If we could cooperate in this effort, we might find that even society is much better and less blame-worthy than we have thought. 


\section{$\mathrm{X}$ \\ THE SURVIVAL OF THE FITTEST}

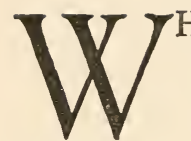

of life.

One or two characteristics of fitness are fundamental, necessary, and evident at the outset. The fittest must be progressive. However great its attainments, if it halts in its progress, it will surely be surpassed and left behind by some steadily advancing form, and progress must be continued through a long series of generations, hence the fittest must be tough, vigorous, tenacious of life. But a host of forms seem able to meet these two requirements.

How can we sift them? We might accept the great line of progress marked out by the logic of evolution. But it is safer and more profitable to notice the facts furnished by geology and palæontology. We will attempt to catch a glimpse of our globe at various stages of evolution, and see what forms are competing for the prize of survival and leadership in the struggle for life. As we pass from stage to stage, we can mark the success or failure of the experiments tried by the most promising competitors in preceding stages.

There was life on the globe long before the beginning of Palæozoic time. The "everlasting hills" have slowly risen, grown old, worn down and disintegrated, often almost disappeared, since bacteria and many less primitive forms came on the stage. Life antedates and outlasts them all. But the earliest forms of life were mostly soft-bodied and left no trace. The few earliest remains teach us little. We catch our first 
glimpse somewhat before the beginning of Palæozoic time. Our chronology is none too definite, our view distant and dim.

At this time a very large part of the globe was covered by a vast primeval ocean. The continents were hardly outlined. North America seems to have consisted mainly of a V-shaped mass of land with its apex near Lake Superior and its arms stretching, one toward Labrador, the other toward Alaska, to the east and west of Hudson's Bay. The eastern and western edges or rims of the continent were marked by uplifts in the region of the present Appalachian and Cascade ranges. We do not know how much life there was upon the land. Our ancestors seem to have been living in the primeval ocean; if they were then living in fresh water, it would not greatly affect our conclusions.

Mollusks were well represented in nearly or quite all their great divisions. Clams, safely ensconced, slumbered in the mud. Other forms with spiral shells crawled on the seabottom. Cuttlefish, somewhat like our present squids, but with their bodies protected by a light shell, swam freely everywhere. They seem to have lacked the parrot-beak of modern forms. This lack was no serious defect; they could swallow any of their competitors whole.

Crustacea, now represented by crabs and lobsters, crept or swam, had jointed legs, and facetted eyes, and were somewhat protected by a coat of light plate armor mainly used for the attachment of muscles.

Swimming in the water above, possibly banished to freshwater, were animals perhaps as large and as dangerous as small earthworms. They were kept away from the rich feedinggrounds of the seabottom by crabs and mollusks. They lived on the minute forms of life which they could sift from the water. These were the primitive chordata, ancestors of the vertebrates. Fascinating worms were abundant, and probably other interesting forms. These we must neglect. They do not concern us and have mostly died out.

Can we pick the winner? Which of these competitors is the fittest, most likely to survive and hold first place. We 
must judge entirely by what we have before us; all later time is supposed to be in the future. The free-swimming chordate form is already distanced and hopelessly beaten. What possible chance has he? The crab is a fairly protected moving animal whose jointed legs and eyes promise a higher organization and successful future.

The cuttlefishes have everything their own way. They can swim swiftly, have sufficient protection, and abundance of food and rapid reproduction. They possess all the natural advantages in environment, are lords of the rich sea-bottom, nine points of the law; and they have size and strength to maintain possession, which should constitute the tenth. But let us not fail to pay homage to our friend the clam, "reclining semi-somnolent" in safety, peace and quiet joy. $\mathrm{He}$ has already attained perfection.

We are hard-headed, practical scientists, we know nothing of the future. We judge by what we see, and by the teachings of the past. Some form of mollusk must be the fittest, there is hope for the crustacean, for the chordata defeat and our pity.

We revisit the earth millions of years later not far from the close of Palæozoic time. The land forming the eastern portion of the United States oscillates not far from sea-level. The great cephalopod mollusks still teem. They have changed form slightly, but little in structure. Crustacea have taken on a more modern appearance. Spiders and insects have appeared on land.

The marked change and progress has been in the descendants of the insignificant chordata. Sharks have appeared with fairly developed internal locomotive skeleton offering attachment to heavy bands of muscles, with paired fins, stout jaws armed with pointed teeth, with large sense organs and no mean brain.

There are ganoid fishes, like our garpikes and sturgeons, superior to the sharks in some respects. They have an airbladder which can be, and often is, used as a lung. Some are mail-clad, others unprotected. They are driving their weaker 
brethren far up the streams into the pools and marshes.

Here the air dissolved in the water is foul; they use the gills less and the air-bladder or lung more. In the water, filled with roots and stems of weeds, the paddle-like fins become jointed and are used partly as legs. Finally during the recurring periods of drought, they will crawl out on land, somewhat like the salamanders of to-day.

Which will survive and make the next great upward step? The cuttlefish is still hearty and vigorous, but has made little, if any progress. The insect has improved on the crab. The future evidently belongs to the vertebrates, descended from the distanced and defeated primitive chordate. The ganoid is promising, the shark is a conspicuous and marvellous engine of speed and destruction. A salamander, driven out on land, crawling among great club-mosses and weeds is not an inspiring spectacle.

We come down to early Mesozoic time. The eastern portions of North America are now well above tide-water, but long bays extend far into the land. Back from the shore, marsh and dry upland alternate. Sharks and ganoids still persist as well as cephalopods. But the amphibian has descendants with whom these could never compete. Reptiles are everywhere prominent and dominant. They swim in the seas and appear to be exterminating the surface-seeking ganoids. On the land they run on four legs or stride on two. They own the rich jungles and rivers with their banks or broad valleys and bordering uplands. Some of them fly with bat-like wings. Others are of huge bulk defended by coats of mail. Life is easy and food abundant. Our present reptiles give but a poor conception of the size and power, swiftness and strength of these ancient forms. Birds are flying through the air, though, perhaps, still somewhat reptilian in appearance. We see a few small, scaly mammals, not one of them a match for the reptiles.

Once more which is the fittest? Later forms have not yet arrived to give us the answer to our riddle. The reptiles offer a great variety of conspicuous forms, some one of which 
ought to succeed. Birds fulfill certain conditions of fitness better. We remember that the whole process of evolution down to this time has tended to the production of muscular forms with well framed skeletons possessing swift locomotion. The bird is a high-pressure engine of marvellous swiftness, with hot blood, keen sense-organs and a good or excellent brain. The bird is certainly of a far finer and higher type than the reptile. What chance has the small plodding mammal?

We are in Tertiary or Cenozoic time. The exit or disappearance of the higher reptiles is as striking as their entrance to the stage; only the inferior have survived. Birds, like some precocious children, have not fulfilled the promise of their youth. The prize will surely fall to some mammal.

There are splendid carnivora, cats or tigers, with powerful, sleek, agile, athletic bodies and long saber-like canine teeth. The herbivorous horses and deer have developed long slender legs, and have taken to flight. The rodents have sought refuge in holes in the ground or on the trees. In the trees we see lemurs or apes, our "furry arboreal ancestors with pointed ears." The cats are having their day. They deserve it. But in Quaternary, Psychozoic time the descendant of lemur and ape reigns unchallenged and supreme. Even the cat cannot hold its ground before the wits, traps, and missiles of man.

It is a strange story. If we have pictured to ourselves the struggle for existence as a mere battle of brute with brute, where the fittest were always the strongest and biggest, we have erred completely. In fact the race is never to the swift nor the battle to the strong. Nature herself in the long run repudiates the strictly gladiatorial theory of the struggle for existence. So repeated and constant an outcome must have some explanation.

One important fact has been already noticed. The external protective skeleton of the mollusk was simple, casy to build, gave immediate tangible advantage, and developed rapidly but 
allowed brief progress. The internal locomotive skeleton of chordata was difficult, slow of development and in conferring advantages, but full of almost endless possibilities of locomotion, sense and brain. Its advantages revealed themselves only after long and wearisome experimenting. The mollusk was shovelling gold out of a pocket, the vertebrate working a fissure vein where the ore, poor at the surface, grew richer as it went deeper.

We remember that the amphibian under great difficulties and disadvantages was on his way to warm blood, a better brain and freer life. These all came very slowly, without observation. The disadvantages seemed at first greater than the gains. The same is true of mammalian structure and habit in general and particularly of primates.

It is evident that we cannot distinguish too sharply and emphatically between dominance and fitness. The dominant forms, hulking reptiles or sleek cats, are those which are reaping to the full the use of some power already attained at the expense or to the neglect of some higher, deep-seated power, as yet very incompletely developed and offering few tangible gains, but of far greater capacity. They gain present prosperity at the expense of all future progress. Such prosperity and dominance must be brief. The experiment can end only in bankruptcy and failure. Reptile and cat must in time yield to the brainier form, but not in one year or millennium. If we focus our attention on any one point of time alone, present or past, if we are near-sighted, the dominant form will surely appear to us to be the fittest, although its doom is sure and downfall near.

The fittest is the form which maintains and improves the best attainments of its ancestors and puts its chief developmental energy into the organs of highest capacity and possibilities. It lives up to and expresses the last term of the logic of evolution. But such organs, or similar institutions, are necessarily complex and of slow growth. At first the rewards of progress are small, the disadvantages and cost of their development are evident and not few. The fittest usually 
seems to be making a losing bargain, while the dominant is conspicuous and his success dazzling.

Why did any of our ancestors choose a path which sacrificed present ease and comfort to future attainment? They had no choice. Stronger and better armed ganoids forced the primitive amphibian ancestor up-stream, and climatic changes drove him out on land. Reptiles taught primitive mammals to be watchful and wary. Morally speaking the carnivora, or possibly reptiles, boosted our primate ancestor into arboreal life.

Nature's system of education is very simple. She puts the progressive form under conditions where it must die or form habits and environment, which will insure exercise of the higher powers and the development of the highest organs. Many shrink back, balk or fail and die. Some, perhaps only a saving remnant, survive and attain the next higher stage. Here again the same process is repeated.

Such a system of education is severe and unsparing. Our ancestors were well fed and contented in the water, they were driven out on land. They had just begun to enjoy life on the ground when they were driven into the trees, whence they were later driven down again. Nature's fairy wand is the spur of necessity. She treated all our ancestors much as Poor Joe in Bleak House complained that Detective Bucket had treated him: "He always kept a-chivying of me and a-telling me to move on."

The chivying process seems necessary. When a group of animals has remained for a time under conditions where struggle and effort are unnecessary, further development seems impossible for them. Life acts like wet plaster. As long as you stir it vigorously, you can mold it as you will. Set it down and it soon hardens into a useless mass.

The pressure of adversity does more than prevent individuals or groups from straying from the right path and to confine them to the line of progress. We have already noticed in the case of man that his deepest needs have often or usually been his best assets. A certain amount of hardship and ad- 
versity is essential to complete development. It has been well said that the surroundings which are most favorable to progress are those which offer the greatest number and variety of stimuli which will continually call into action all the powers of the individual. A life of ease means lack of stimuli to action, hence the full development of but few powers. Power and efficiency come only through vigorous exercise, and strength through struggle. Nature sifts out the weak-willed as well as the weak-bodied.

The obstacles may be so great that it is almost or quite impossible for the average form to overcome them and survive, in this case few are spared. But progress comes only through the steady testing and training of the growing power and compelling it to accomplish to-day what was impossible a year or millennium ago.

"Suffering and hardship do not, as a rule, abate the love of life; they seem on the contrary to give it a larger zest. The sovereign source of melancholy is repletion. Need and struggle are what excite and inspire us; the hour of triumph is what brings the void." 1

Yet Nature's severity is really kindness. She is really continually spurring her favorites to a higher and keener enjoyment. Idleness is unbearable to the healthy, lack of all hardship unendurable to the strong. Normal exercise of any organ always brings pleasure; the higher the power exercised the higher the joy. This is one reason why the motives peculiar to each higher plane of life supersede and dominate those of the lower.

Why has no form ever enjoyed dominance for a time and then added the higher power and become also fit? Why did not some ancient cat develop tooth and claw as long as these were highly profitable and then devote its energy to developing a thinking brain? Fortunately no cat ever did this, otherwise learned societies would have met on the back fence and you and I have been spared the malady of thought. There are many reasons. Only a very prophetic cat could have fore-

${ }^{1}$ I26:47. 
seen any advantage in such a change. If it could have awakened to a dim feeling of such a need, it would have been too late for it to turn back.

Nature seems to say to every group of animals: "Try whatever experiment you will, along any line. But once started you must keep to that line and discover its logical result." That is the "law of the jungle." A wise, if illiterate, minister said that the most important text in the Bible was: "They got a-going, and they couldn't stop." The fittest is always the parent, never the child of the dominant.

Dominance and progress are mutually incompatible in the same species. You can very easily fail of both, you can choose between them, you cannot have both. Fitness may in the end triumph, it probably or surely will, you will not live to see it. This seems true of animals and men. The logic of evolution applies to man just as well as to cats and apes.

Man, like the animal, must cultivate steadily and at all cost the powers which raise him above all lower stages. He must find higher and more difficult exercises and worthier forms, expressions and habits than his ancestors attained, otherwise there is no progress. He must cultivate above all others the powers which have the broadest and highest capacities and possibilities. These must be united in one symmetrical person controlled by these highest rational powers. Such are the moral and religious powers which have raised man to his present lofty position, and have indefinite capacity for future development.

Socrates is being entertained at a banquet in the house of Gorgias. The conversation turns first on rhetoric, then on justice and life. Callicles has exhorted Socrates to practice the art of dealing with realities, and that which shall gain him a reputation for common sense; to emulate not the men who waste their time in probing useless questions concerning truth and justice, but rather those who possess means and reputation and all other good things of life. He has assured Socrates that the end of all his work will be sentence in the courts and death by the vote of his fellow-citizens. One after 
another Socrates silences his opponents and closes the discussion with a statement of his own belief:

"So, bidding farewell to those things which most men count honors, and looking onward to the truth, I shall earnestly endeavor as far as may be in goodness and thus live and thus, when the time comes, die. . . The best way of life is to practice justice and every other virtue and so to live and so to die. This way, then, we will follow, and we will call on all other men to do the same; not that way which you believe in and call upon me to follow for that way, Callicles, is worthless."

Callicles and Socrates differed in their standards of value. There are many molluscan or carnivorous systems of philosophy abroad to-day. But their defenders fail to give due credit to the original discoverers and practitioners of their school. Socrates' language sounds strange and foreign to them. It is not up to date. But were their systems not disproved as inadequate by human experiment and experience before the close of Palæolithic time? It is the old story: Socrates standing for fitness, Callicles for dominance.

Callicles was a shrewd prophet. Socrates was condemned to death and refused to listen to his friends who had bribed the jailer to let him escape. He could hear the pleading of the laws, "ringing in his ears like the music of the flutes of the Corybants and nothing else." He drank the hemlock cheerfully, and died the gentleman that he always had been.

Says Wundt concerning the goal and ends of life according to the philosophy of Plato and Aristotle: "The end and goal of life is a harmoniously developed soul whose powers are not divided into hostile camps but every one subject to the whole; all guided by the highest power, the Reason, which alone has absolute value and worth in itself. . . Thus arises a harmonious soul, a personality complete in itself. Only he who has attained this stage possesses all the virtues even the highest, wisdom, the virtue of the rational aspects of the soul." 2 But Greek literature, art and philosophy are all

$2 I 25$. 
"back-numbers." We have already quoted Huxley's definition of a liberally educated man.

Says William James, the Pragmatist: "In all ages the man whose determinations are swayed by reference to the most distant end has been held to possess the highest intelligence. The tramp who lives from hour to hour; the Bohemian whose engagements are from day to day; the bachelor who builds for a single life; the father who acts for another generation; the patriot who thinks of a whole community and many generations; and finally the philosopher and saint whose cares are for humanity and eternity - these range themselves in an unbroken hierarchy." 3

James' patriot, to say nothing of philosopher and saint, seems to me to have caught and been persuaded of a vision and promise so grand, dim, distant, hazy and uncertain in outline, to be investing so largely in uncertain because distant "futures," that he must be walking far more by faith than by sight. But we will let that pass. Any description of a great life is always cold, inadequate and unsatisfactory. We are really stirred by the idea of fitness only when we see it incarnated and embodied in a Lincoln or Socrates or any one of Heine's "apostolic succession of great souls."

But these men have a far higher use. Nature trained man to the discovery and practice of fitness largely through tribal pressure and compulsion. Then she set him free to follow his own conscience as a moral person, who cannot be forced into the highest stage of progress. He can be drawn or attracted by loyalty to a hero worthy of the name.

The dominant forms pass away, the fittest endure, strive and progress. Nature seems to look upon the dominant as a necessary but temporary nuisance and evil of which she makes the best use she can. She turns such to account by making them police the road or stimulate and exercise the fit. Then she weeds them out and kills them off. No dominant form is ever the ancestor of anything higher, or of any descendant worth our attention. No one of our ancestors has ever been 
dominant. It is not in our heredity, it is always an acquired character. In most of the views and theories not to mention practices, of to-day dominance and fitness are regarded as synonyms. They are really antitheses, mutually incompatible.

All our mammalian ancestors, and birds and mammals generally, have been social forms giving mutual aid. Is Huxley speaking the truth when he says: "The practice of that which is ethically best - what we call goodness or virtue - involves a course of conduct which in all respects is opposed to that which leads to success in the cosmic struggle for existence" ?

Says Thomson: "In thinking of the process of Natural Selection it is of real importance to recognize, with Darwin, that the phrase 'struggle for existence' is used 'in a wide and metaphorical sense,' including much more than an internecine scramble for the necessaries of life,--including indeed all endeavors for preservation and welfare. Not only of the individual, but the offspring as well. . . . It is much more than a long-drawn-out series of family quarrels ending in more room and food for a few surviving members: it may often be more justly described as an endeavor after well-being. And what may have been primarily self-regarding impulses become replaced by others which are distinctively species maintaining, the self failing to find realization apart from its family and its kindred." "The reason why we are so much concerned with getting away from an ultra-Darwinian picture of Nature is not merely because it seems to us inaccurate, but because the libellous conception projected from human society upon Nature has been brought back again to society as a guide and sanction of human conduct, even as an ethical and political ideal." *

And yet during the building up of the neuro-muscular system by worms and early vertebrates, there was much of the gladiatorial struggle and competition to the death. There are undeserved misery, pain, suffering and injustice still. We cannot deny it. We are here to remove or at least mitigate them. Let us assume honestly and squarely our share of the

${ }^{4}$ K. 164 . 
blame even if we can hardly pronounce Nature innocent. There is something wild, untamed in us both. We must get on together, as best we can. But let us never forget that in the end and long run Nature is always on the side of fitness. ${ }^{5}$ Is it, perhaps, the old story of Gareth and Lynnette?

Nature is masked, and life is an enigma, always a struggle, frequently a death-grapple in the dark. It is altogether too big and grand for our understanding. Every attempt to reduce it to a scheme is doomed to failure. Perhaps it was so intended and planned. It always has been and always will be an investment in futures, an adventure; and we would not have it otherwise. In the end, in spite of her jeers, pricks and buffets, Nature is for us, not against us. This is enough. Impavidi progrediamur. Gentlemen-adventurers all.

Says Bergson: "All the living hold together, and all yield to the same tremendous push. The animal takes its stand on the plant, man bestrides animality, and the whole of humanity, in space and in time, is one immense army galloping beside and before and behind each of us in an overwhelming charge, able to beat down every resistance and clear the most formidable obstacles, perhaps even death." 6

5 T. 228.

${ }^{6}$ I. 27 I. 


\section{XI}

\section{PERFECT HEALTH}

TEACHER of philosophy once said that Aristotle
after hearing and contributing to the endless fas-
cinating discussions in Plato's Academy came away with a passion for the obvious. There is nothing dazzling about obvious truths any more than there is about fitness. Hence we are quite apt to forget both. But they are always worth thinking about. Indeed a passion for the obvious is one aspect of genius. Aristotle declared that it was obvious that a certain amount of wealth was better than poverty, and that health was better than disease.

Health is evidently the first prerequisite to fitness. This also is a truism. It is equally evident that perfect health is very rare. Statistics collected during the Civil War showed that only about one-third of the men drafted for service were fit to bear arms, and many of these proved unable to endure the hardships and strain of a soldier's life. Probably not one in ten was what an athlete would call fit. Nearly all showed minor weaknesses.

All of us remember certain red-letter days in our lives. We awoke in the morning from a refreshing sleep. The air seemed to tingle with energy, we were eager to begin the day's work; and what a day it was! Work became play and went on rapidly, easily, successfully. Difficulties and hard problems only stimulated instead of depressing us. Obstacles which had blocked our paths dwindled and disappeared. It was our mountain top of vision, and we went in its strength many days. Fears cast no shadows, we saw everything clear and in due perspective. 
It is difficult to estimate the value of such a day. Was it five or twenty-five times as great as our average? It was our day of as nearly perfect health as is possible for us. Such days are few and rare.

No physician could have told us why the next day was dull. The physical change was probably slight, and may have affected a very small part of our bodies: a limited slight inflammation, a very little uneasiness, a local weakness or strain, a slight general lassitude or weariness. It was only a slight indisposition, but it cut down the zest and value of our work far below our average. Our health was still good, but not perfect.

The trained athlete is well aware of these facts. A very slight breach of training would not perceptibly injure his health, but it might easily cost him the race. He must be at the top-notch of condition. It is obvious that a slight physical betterment may double our efficiency.

Our strength and endurance are measured largely by our weakest organ or part, like the weakest link in a chain. If our lungs furnish only fifty per cent. of the needed oxygen, good muscles cannot do their full amount of work, and will probably degenerate. If our feeble stomachs can digest only " educator" crackers and broth, where is the fuel for the microscopic neuro-muscular engines? We need a trained athletic digestive system as the foundation of health and greatness.

We must say the same of every organ. Temporary weakness of any smallest part is immediately telegraphed to the nerve-centers and depresses the tone of the whole body. This universal tyranny of the weakest part is probably most severe in individuals of highest culture and greatest refinement. When the deacon built a shay whose weakest part was just as strong as the rest, he made a very serviceable as well as durable machine. All this is obvious.

We are slowly learning the supreme importance of proportion and symmetry in the human body. The old-fashioned gymnast was a monstrosity, with overhanging shoulders, bulging arms and shipwrecky legs. He looked like a triangle walk- 
ing on its apex. The modern athlete would furnish a model for a Greek statue. Proportion, symmetry and harmony are the foundation and essence of both strength and beauty.

Our American maxim, "You can't have too much of a good thing," is obviously untrue. Said the genial and wise old writer of Ecclesiastes: "Be not righteous overmuch, wherefore shouldst thou destroy thyself? Be not overmuch wicked, neither be thou foolish, why shouldst thou die before thy time?" The wise old Greeks said: "Too much of nothing." Symmetry and proportion giving strength and beauty are necessary for the mind as well as the body. Mentally many of us are monstrosities, cripples or " reversed cripples."

What constitutes a healthy nervous system? What would be its most marked characters, if we could discover so rare a jewel? Its end and purpose, quite obviously, is to secure that every incoming stimulus shall call forth from some muscle or muscles an adequate response, one suited to the emergency.

A fly alights on my nose or head, stimulating my skin. His tickling is disagreeable and his presence undesirable. It is not necessary to think much about him. Almost unconsciously I wave my hand, and he departs. I may do far more; smite at him and excite myself by addressing winged words as he sails gaily away. I have wasted valuable energy.

Our whole day's work is no more nor less than a series of responses to stimuli coming from without or within. The success 'of the day's work is measured by the adequacy of the responses, for which, and usually not for the stimulus, we are responsible. The stimulus is merely an occasion.

I awake in the morning, and the first horrible responsibility of the day confronts me. I must get up. Just how or why I do it, I do not know. I find myself on the floor. The chilly air stimulates me to dress; the pangs of hunger call me to breakfast, and the bell to my work. So it goes all day long, stimulus and response.

We are continually pelted by stimuli, like rich men besieged by begging letters. To respond to every one means nervous bankruptcy and insanity. Our first question must be: is it 
really worth while to do anything about it? Pick out of a college class of one hundred men the ten who appear the laziest, and you will have nearly all the best trained athletes. Most of us, by lively hustling, waste enough nervous energy in one day to last us a week; and then wonder what it was all about. Hustling is conspicuous but not therefore fit. There is "power in repose." We hurry and worry; and these, according to the Arab proverb, are the Devil. Don't waste the time of a strong man who tells you he has plenty to spare. Try that experiment on the man who has none; you will do far less harm. A healthy nervous system is first of all economical. There is in it nothing of the hair-trigger releasing an explosion at the slightest touch; nor is it like a sponge giving out only under pressure. "Too much of nothing."

Continual responses smooth grooves of least resistance in our nervous system until all its energy tends to pour out along these paths. Hence arise habits which we have formed or allowed to grow. William James has spoken of them far better than I can. ${ }^{1}$ The only genuine gentleman is the man who could not be anything else. This too is obvious.

The different centers in our nervous systems may be compared to the local centers or switch-boards of the telephone system of a great city, all connected at one center. It might better be compared to the system of control and communication, the organization, of a great army whose soldiers would correspond to our muscular fibrils. There are headquarters for companies, regiments, brigades and divisions. Behind and above all are the headquarters of the general in supreme command, a chief of staff. So we find in our bodies a hierarchy of centers of different levels, a "reservoir of indetermination," all having their final seat of control in the thinking mind. ${ }^{2}$

It is a long circuit for impulses through this highest center. Many or most never reach it, but are shifted or arrested farther down. In this highest region there is opportunity for delay, for mutual inhibition or conflicting impulses. There

${ }^{2}$ I35 Chaps. II. V. 
are always several or many outlets for an outgoing impulse, leading to very different responses in word or deed. Time and occasion must be taken into account; it is sometimes best to wait a little. Many or most of the impulses are discarded, or neglected and straightway forgotten; some are perceived, recognized and stored up in the memory until time and occasion are ripe. There is much sifting and selection; and we may well take heed what and how we hear, feel and remember. When the response comes, it often seems a composite result of many stimuli, no one of which alone would have called it forth in its final form. Here are the place, opportunity and necessity for the control of the marvellous system by a perfectly healthy mind.

Now our phraseology changes. We no longer speak merely of vibrations or material impulses, but somehow in correlation with these we recognize that mind has appeared on the stage. Aladdin has rubbed his lamp. We are intelligent, feeling and willing beings; and these powers or aspects govern our actions. Physical health demands the highest and most harmonious development of all our organs. One weak spot may destroy the efficiency of the whole body. Must not the same be true of the mind? This gives room for almost infinite variety of possibilities.

We say that our first need is to see things exactly and clearly as they are. This is well and easily said, and it does not seem to demand too much from a healthy vision. But it is not easy, though it may be natural. We all see through the variegated glasses of heredity and early environment and education. Every object of practical interest is seen through the glass of prejudice, and the prejudices of the ignorant are mild and harmless compared with those of the trained specialist. We see it from our own standpoint, rarely in its true perspective, and relations with the whole; never from all sides and in its place in time, "sub specie ceternitatis." The blind spots in our mortal eyes, due to defects of inheritance, training, disuse or misuse and degeneration, render many of its finest points invisible. The same object or event has a totally 
different appearance, meaning, value and interest for different men and women, and for the same man at two o'clock of a restless night and an hour after breakfast the next morning. Finally, the great thing is to see men, women, and especially boys and girls, not only as they are but as they may become. Without this vision men and people perish.

We hear much, and cannot think too much, of the psychology of interest. ${ }^{3}$ Interest is focussed and absorbed attention; and focussed attention means will, purpose, and action along the line of the absorbing, controlling interest. The object of interest, has great value in our eyes, though others may not share our estimate. Most of us have some hazy, more or less distorted sense of values. Few of us have any fixed intelligent scale by which we measure values of different degrees and especially of different quality and kind. That which is of highest value and therefore of most intense interest and closest attention becomes the end of life.

The Westminster Catechism took it for granted that man has a chief end. This view is now a back-number, though we may return to it. Our denial or forgetfulness of it has disadvantages. The architecture of our life, if we have any, is of the Queen Anne style, mostly additions and departures; and the same defect mars our minor efforts. To change our illustration, our course even in fairest weather is that of a boat carrying much sail, beating against the wind. The zigzag seems to be our line of beauty, as "jazz" is our ideal of melody.

This sense of values was a characteristic of the Hebrew and Greek mind. The whole "wisdom literature" is a study of values. It underlies all the teaching of the Master. His great question is: "What shall it profit a man?" The hero of his most striking parables is the man who knows a really good thing when he discovers it, a unique pearl, a hidden treasure. He was a dealer in futures and loved such. The same is true of the wisdom of Greek philosophy, art and literature, with its marvellous clearness, wholeness and sanity of

3 I42. II4. 188. 
view, its perspective and sense of symmetry and proportion, its appraisals and appreciations in art, literature and life. But why waste time on Hebrew or Greek thought? We are pureblood, modern, nordic Aryans.

Evidently the foundation of perfect sanity or mental health is a high harmonious development of all our mental and physical powers; a well proportioned, beautiful, strong body with a sound mind whose fundamental character is a wisdom which is a sure touchstone of values in ends and means. How this can be attained, what is the source of such wisdom, or the path to her house is another question.

A shrewd old country doctor used to say to a young mother: "Madam, don't forget that Nature has made that baby about right. Don't you spoil it." All babies are not made and born all right. Many fail to measure up to Nature's standards and die, others are killed off during the first year. The constitution of the baby is an hereditary endowment and weak or strong accordingly. "Our constitution is an entailed estate which must pass to our heirs with all its worth and encumbrances." If the children are to be healthy, training must begin with the parents.

What does Nature demand of the baby? If he eats, digests, sleeps, breathes and grows well he is doing his whole duty. We test him mainly by the steadiness of his growth in weight. Soon he begins to sit up and to kick, and his shoulder muscles swing his arms like flails. There is implanted in him a tendency to use every organ just as soon as it is mature enough to be stimulated by exercise to further growth. When it has had exercise enough, it and he tire. The early use of the heavy fundamental muscles of trunk, shoulder and thigh stimulates general health and strength. It stimulates also the development of the fundamental nerve-centers, and fortifies the whole nervous system against weakness and collapse. Here the foundations of health and strength are laid deep and strong. The baby and young child are chiefly animal. Let them be healthy animals in a healthy environment. 
The kindergarten period is predominantly sensory, but may easily be made too much so. The young child enjoys running and will soon begin to climb, possibly in honor of his arboreal ancestors. All this is natural and developmental. Sensation, imagination and imitation mingle in varied amounts in the activities of this period.

Between seven and twelve the social but competitive games appear. Boys and girls play in groups, but every one usually plays for himself. Tag and other running games are the earliest. These still involve the use of the heavier muscles and exercise the largest amount of muscular tissue with the smallest expenditure of nervous energy. These exercises stimulate the growth of heart, lungs and all the visceral organs without over-taxing the very immature brain. If one organ is undersized, it has to work the hardest to meet the requirements of the game and receives the most exercise and stimulus. Then the child tires and rests. No one can fail to notice in healthy children how rapidly periods of most vigorous exercise alternate with change of play or complete rest. The body grows fast and symmetrically, and the child waxes strong.

Play still furnishes the best mental training. Watch a game of tag. The sense-organs are all alert. The attention is well focussed. The will is being trained. The child must size up the situation, and grasp the opportunity once for all. He cannot stand shivering on the brink of action. Thinking, willing and doing are united. The same movement is repeated until perfected, and with undiminished interest. The child forgets himself and loses shyness and self-consciousness in the game. As he grows older, the opportunity for skill, thought, plan and strategy, constantly increases. He is learning far more than the rudiments of the art and science of success in life.

Here he must act on his own initiative. There is no one to keep telling him just what to do or more frequently what not to do. He is placed more nearly in the position of the boy on the old-fashioned farm, who had to help himself out of every emergency as best he could. The heaviest losses in our modern education lie along these lines. 
The kindergarten period is one of comparative peace. Now the child is learning to get on with his fellows. He is finding how much he can claim and when and how much he must yield; and how to yield good-naturedly. It is no easy lesson in this day of small families. Yet it must be learned, or he will grow up to sorrow. A somewhat robust friend of mine is apt to explain the weaknesses and defects of certain adults by saying sadly: "They did not play enough with bad boys on the village street when they were young." There is usually a grain of truth even in such a heresy. The result of the experience is worth far more than it costs, even if the price is sometimes tears and bloodshed or a black eye.

Here the boy and girl receive their first lessons in the grandest art or science of life, that of making many firm friendships. If they do not learn to make them now, they probably never will.

The conception of fair and unfair play is almost the first genuine and spontaneous moral distinction which the child makes. He is still very hazy in his ideas as to rights of property and far from clear in his theories as to the necessity of truthfulness. But he is sure that the boy who does not play fair or cheats is mean, which is his word for total depravity. This germ has marvellous possibilities, if fostered and cultivated. If you despise or neglect it, if you attempt to replace it by your own adult system of ethics, the boy and girl lose faith in their own conceptions of morality, they can neither understand nor appreciate yours; they are left without any system which appeals to them, and their last state is worse than their first. Indeed they have fallen from a high estate. Despise not the day of small things.

We must carry the spirit of play through adult life. Joy, like sunlight, promotes health. The work from which the play element is absent can never be of the highest order. Art is like play in that it is its own reward. Opportunity is an even larger and higher word than duty, and opportunity must be enjoyed.

About ten or eleven new instincts begin to emerge. We 
name only one, the collecting instinct. This leads to the close study of nature and of many realms of human activity. All these studies broaden life and increase its joy.

We must hasten on to the close of school life to the last part of the period of adolescence in the study of which Hall has done so fine pioneer work. Boy and girl have attained nearly their adult size and proportions after alternating periods of increase of height and girth. They feel the rising tide of vigor and power. They are still far from adult endurance, when the tissues have toughened and hardened. One great danger is the exhausting over-excitement of too intense social life. Here again moderation.

The games of the period are equally characteristic. They are group games played with sides, each of which represents a gang, class, school or town. They demand high physical development, self-control, quickness, endurance; more complex movements, the use of finer muscles and of higher centers in the brain. Strategy counts heavily. The boy plays with his head, and is a practical psychologist; recognizing the strong and weak points in physique, temper, character and wit of every opponent. Not a movement or gesture escapes him.

He is a member of a team and learns to submit to criticism, training, discipline. We intellectuals may well grant that there must be some reason for the preference by captains of industry of young men who have excelled in athletics. It is a very suggestive phenomenon. The chief sin of big business is that it absorbs the men whom we need as teachers and preachers to educate the generation which will make the America of twenty years hence.

The attainment of full growth and muscular power, the large heart and lungs, the well oxygenated blood, the activity and young vitality of all the tissues, give buoyancy and courage, a sense of power and longing for entire freedom and revolt against control. A new world opens before the boy as fresh and fair as on the morning of creation, a new life boundless in opportunity, endless in scope and time. $\mathrm{He}$ is sure that 
plodding parents and teachers cannot understand him or the glories of life. Unfortunately he is usually right.

He must gird his loins and go whither he will; must taste of every experience, is willing to meet both joy and pain with "frolic welcome." He has not yet been saddened by experience or disillusioned by disappointment, nor trained to endurance.

Nature is loosing her leading strings and setting him free to forge his own character. In old times the adolescent ran away to sea, now we send him to college. Here, beyond the benevolent watch of neighbors, he begins to experiment in life, to make his blunders, to find himself, his strong and weak points, and to grow into a man.

Authority has only a superficial hold upon him, tradition still less. The influences of early home training rooted deep in his subconscious life are exceedingly powerful for good, sometimes for evil. Yet he cannot or will not stand alone. Individual judgment and conscience develop very slowly. To understand him and his actions under certain conditions you must study the psychology of the mob.

$\mathrm{He}$ is a mixture of contradictions, an enigma to himself and us. He might well say: "My name is legion for we are many." In the ferment of youth all that is trifling and worthless comes to the surface, the strong and sweet are hidden beneath the froth.

He has no trace of a conception of the meaning and value of time, lives in the present moment, cannot play a waiting game. If the sun shines to-day, it will always be cloudless; if the maid of his adoration has frowned, he is in despair; she will never smile again. He betrays all his momentary conceits and foolishness; his deep humiliation over his blunders, failures and sins he keeps to himself.

Nature puts a shell around chicken-embryos to prevent meddling intrusion with her vital processes. She puts a similar shell around the adolescent. His confidence is reserved for friends of his own age. On the whole it is best so, our meddling fingers might mar the process. He must fight his own 
battles. If his father will help him, let the father renew his youth; it will not hurt him.

It is the epoch of the reign not of cold judgment but of the heart out of which are the issues of life. Feelings and emotions are racial, crystallized out of ages of human experience, sifted, tried and tested. Opinions, and most of our theories, are individual, of yesterday, and will be forgotten to-morrow. Trust his feelings. Deal honestly and squarely, play fair with him; and the harder you apply curb and spur, the better he will like you in the end. He is searching for a leader, and usually, like St. Christopher, he will begin by following the strongest. In time he will find his hero and king.

$\mathrm{He}$ is overflowing with loyalty. He has probably been converted at fourteen or sixteen, the years of rapid increase in girths and lung-capacity, marking rapid increase in vitality and vigor. Give him a virile Christianity, and you have the stuff of a hero and martyr. If he is healthy, he is an idealist.

$\mathrm{He}$ is a fine target for criticism. We can hardly fail to hit and probably wound him, if that is what we wish; though he will probably not show it, and our missiles may rebound. If we wish to correct him we must look back a few years, remember and confess some of our own vast ignorance, a few choice specimens of our blunders and follies, our perversity and stupidity, not to mention sins and transgressions. Then he may listen to us. If we are too superior, we cannot meet him on his own ground of experience. If he has little respect for us and our opinions, the fault may be partly ours. This, again, seems quite obvious.

At his best he is a very attractive and exasperating, crude, immature, inexperienced irresponsible young barbarian, reminding us of the primitive Achæan or Celt. As the Irish woman said of her son: "Twixt the plague of his living and the fear of his dying I have no peace in life." We enjoy the vigor and boldness of his thought and expression; the freshness and freedom of his argument or assertion untrammeled by logic, facts or experience. He will have experience, 
he is having it. Let us rejoice in his courage. We cannot help liking him. On the whole, he has a fairly healthy mind in a very healthy body. "Eden isn't quite done yet," as Mark Tapley said to Martin Chuzzlewit, but under proper cultivation it is a field of great promise.

Has not Nature done her full share by implanting compelling instincts and tendencies? Has she not started boy and girl on the road to fitness? If they complete the line of development marked out by her in play-instincts, will they not come to something pretty fine and grand? Is failure, if it comes, due to Nature or to bad nurture, or the clumsiness of artificial education, the emptiness and staleness of artificial environment? Environment is largely forced upon the child, in spite of himself and Nature. Let us be men enough not to try to throw on Nature the blame for our own weakness, faults and sins; that is childish.

Our young friend revisits us at thirty. Physically he looks as vigorous as at twenty and with more endurance. As an athlete his powers have probably culminated. Whether this is necessary, I dare not say. He loses more hours and days from his work through slight indisposition, brief acute attacks of indigestion, bronchitis, and similar ailments. Nature is seeking out his weakest point and attacking it, soon she will lay siege. His body is passing its prime. It holds its highest level for only a few years. The effect on his élan and morale is not good. Dr. Johnson probably exaggerated somewhat when he said: "Sir, a sick man is always a scoundrel"; it is not always true.

He has found his place and calling, and is successful in his work: doctor, lawyer, merchant, or chief. We are proud of him. He is a master in his craft and knows his business. Too often he has focussed his attention steadily on this point. His bundle of interests has shrunken accordingly. He no longer cares for art, music, literature, or general science, or for questions outside of his own calling. His sympathies have narrowed. Fie reminds us somewhat of a horse driven in 
blinders along a dusty road with green fields and flowers on both sides invisible to him. He is growing near-sighted from watching his steps.

He has found the world different from his youthful expectations. Now he knows it as it is and can smile at his youthful dreams and illusions. $\mathrm{He}$ is a realist accepting the world. He conforms resolutely to the actual. Specialization is necessary, every one must do his bit. The more minute the speciality, the narrower and more complete and absorbing the specialization, the greater the rewards. The "bit" is not big enough to allow breadth and symmetry of development. Mentally the man now reminds us of the old-fashioned gymnast trained to use only a few muscles, and perform a few striking tricks or feats on one piece of apparatus amid the applause of the spectators. He is on the road to dominance, a highway "paved with good intentions." $\mathrm{He}$ is in danger of becoming a torso, a cripple; or an even worse monstrosity, a "reversed cripple." He may yet be forced to plead the old excuse: "As thy servant was busy here and there, the man was gone." This danger besets every calling.

We cannot all do all things. Every one must do his little part, and contribute only his best. Every man must specialize in his work. But even in work, and especially in leisure - which, according to Aristotle, is the end of all labor, - no part or power of body or mind can say to any other part: "I have no need of thee." The neglected, disused or misused, part weakens and is likely to become diseased. It remains the weakest spot and will tyrannize over us and drag us down.

We are all of us victims of over-adaptation to a narrow and artificial, unnatural environment. Through over-adaptation we become passive creatures and creations of present surroundings, and environment, not their masters and moulders. The artificial fashions and conventions of every era pass quickly away.

Biologically this has spelled, sometimes temporary dominance to a few, always degeneration and failure in the end. 
Our present standards are obviously purely economic, regardless of any not immediate future. But even the economist may grant to the biologist that it would be well if this arrest of growth, over-specialization, decay of powers, and asymmetry, should be postponed as long and mitigated as far as possible.

There is a large grain of truth in Osler's theory; William James tells us that old-fogeyism begins earlier than most of us think, usually about twenty-five. ${ }^{4}$ As a rule, the longer the period of development, and the later the attainment of maturity, the higher is the adult form. Precocity in development is a dangerous symptom. The height of a man's attainments depends largely upon how long he can continue to grow. Hence the value of young men who persist in boyish immaturity and seem unable to find themselves. They remind us of the generalized form from which, rather than from the specialized, the higher stage always springs. Specialized forms are barren, and over-specialized are unhealthy and decadent. $^{5}$ This is the biological rule for species, and it seems equally applicable to individuals. The only powers on which one can afford to specialize are the highest manifestations of the spirit, and a proper healthy development of these ought to imply the use of all the lower powers.

There are always some very healthy young men who refuse to allow their vocations to limit their sympathies and interests and thus stop development. They maintain their health and grow long after others have begun to deteriorate. They live and flourish in enjoyment of more than youthful vigor, of the endurance of maturity and the wisdom of old age, until they are cut down untimely at four-score or later, irrefutable arguments for immortality. They always retain their youthful courage, enthusiasm and idealism. Experience has made them wise, and they have attained a steady, indomitable, infectious hopefulness impossible to youth. They are obstinate believers in the fine and good which they discover and call forth in men and in a goodly world.

\footnotetext{
${ }^{4}$ I42. 32. 46. I. I33.

5 I.42. 72.
} 
Their humor is a symptom of long experience well used, of shrewd, broad views, kindly amused sympathy and right perspective; in one word, of wisdom. They seem to think that the chief reward of life, if not its chief end, is the joy of living. Somehow they find or make it exceedingly attractive, even if their "success" in life may not equal that of men who through exploitation and over-adaptation have attained dominance.

They are especially attractive to youth. We found it good to be with them, for virtue and healing went out from them. Their strength is "as the shadow of a great rock in a weary land." There is always something infectious about them, and people press to them to be infected; though they rarely preach, and never have been caught setting an example.

Is it possible that such men ${ }^{6}$ are the real leaven of society, rather than the reformers, example-setters, teachers and preachers, educators, legislators and even the saints and philosophers? Are they the ones who bring in the dawning environment of a healthier and better world with which legislators and statesmen, and even practical men must reckon? Are they the coming men?

It does not seem impossible when we remember that when law had proved inadequate and weak, and philosophy could not lift men, and thinkers had become discouraged, a Jewish carpenter threw one perfectly healthy, symmetrical and infectious life into human society, which spread and seems destined to turn this old world of ours right-side-up. If his audacious experiment does not succeed it is hard to imagine what can. It must succeed. Man is surely coming, though he has not yet arrived.

Let us not mistake dominance for fitness. We live in a world of space, extension, form and size. Here bigness counts. Of the extension, form and size of mind and life I cannot conceive. We live also in a world of time, duration and durability, hence of qualitative characters and values. We cannot afford to leave time out of account as some of us seem

${ }^{6}$ E. g. Doctor Edward Hitchcock. 
to do. Here quality outranks bigness and a small, enduring minority with time on its side will win in the end; especially if the minority is an apostolic succession of great infectious souls. Nature also is on the side of those fittest, and will not be denied.

Nature obviously urges us to be healthy, fully-developed, symmetrical, strong and beautiful in mind and body. A wise old classical teacher used to explain with enthusiasm to successive classes of young barbarians that in Hebrew, Greek and Latin, salvation meant restoration to, and maintenance of, perfect health; that health, haleness, wholeness and holiness are all akin in root and synonymous. Perhaps he was quite right. It looks so. Salvete et valete. 


\section{BIBLIOGRAPHY}

\section{GENERAL}

A. Darwin, C. H., Origin of Species, London, 1859

B. Darwin, C. H., Descent of Man, London, I87 I

C. Wallace, A. R., Darwinism, London, I88y

D. Huxley, T. H., Evidences as to Man's Place in Nature, New York, 1863

E. Huxley, T. H., Lay Sermons, Addresses and Rerierus, New York, I873, Especially, “A Liberal Education" and "Natural Knowledge"

F. Kropotkin, P. A., Mutual Aid, a Factor in Eìolution, New York, 1903

G. Osborn, H. F., Origin and Evolution of Life, New. York, I917

H: Lull, R. S., Organic Evolution, New York, 1917, Bibliography

I. Bergson, H., Creative Evolution, New York, I9I I

J. Thomson, J. A., A System of Animate Nature, 2 vols, New York, I920, Bibliography

K. Thomson, J. A., The Bible of Nature, New York, I908

L. Geddes, P., and Thomson, J. A., Evolution, New York, I9I I

M. Jordan, D. S. and Kellogg, V. L., Erolution and Animal Life, New York, I907, Bibliography

N. Kellogg, V. L., Daruinism To-day, New York, I907

O. Conklin, E. G., The Direction of Human Erolution, New York, I92 I

P. Crampton, H. E., The Doctrine of Evolution, New York, I9I I

Q. Morgan, T. H., Evolution and Adaptation, New York, 1903

R. Fiske, J., Destiny of Man, Boston, I884

S. Fiske, J., Through Nature to God, Boston, I899

T. Smyth, N., Through Science to Faith

U. Wundt, W. (Trans. Schaub, E. L.), Elements of Folk Psychology, New York, I9I6 
V. Wilder, H. H., History of the Human Body', New York, I909 W. Wilder, H. H., Man's Prehistoric Past, New York, 1923

X. Newman, H. H., Evolution, Genetics and Eugenics, Chicago, I92I

Chapter I. the Coming of life. See G. M. H.

I. Minchin, E. A., Evolution of the Cell, Nature, Oct. I4, I9I5 Vol. XCVI, No. 2398 , p. 185

2. Conn, H. W., The Story of Germ-Life, New York, I9I3

3. Buchanan, E. D., and R. E., Bacteriology, New York, I92 I

4. Calkins, G. N., The Protozoa, New York, I92 I

5. Jennings, H. S., Biology', New York, I9I4

6. Jennings, H. S., Behavior of the Lower Organisms, New York, I9I5

CHAPTER II. THE COMING OF A BACKBONE, AND CHAPTER III, THE RISE OF LAND LIFE. See $H$.

Iо. Cockerell, T. D., Zoölogy, New York, I920

I r. Borraddale, L. A., Manual of Elementary Zoölogy', London, I920

12. Shull, A. F., Prinicples of Animal Biology, New York, 1920

I3. Woodruff, L. L., Foundations of Biology, New York. 192.2

14. Newman, H. H., Vertebrate Zoölogy', New York, 1920

Or any textbook of Zoölogy

CHAPTER IV. THE COMING OF SAVAGE MIN.

See H.R.U.V. See H.

15. Osborn, H. F., Age of Mammals, New York, I9Io

I6. Loomis, F. B., Adaptation of Primates, Amer. Nat. Vol. XLV, I9II, p. 479

17. Barrell, J., "Probable Relations of Climatic Changes to Origin of Tertiary Ape-Man," Sci. Mon., 1917, p. I6, N. S. IV 
I8. Berry, E. W., “Environment of Ape-Man,” Sci. Mon., N. S. Vol. III, I916, p. I6I

19. Jones, F. W., Arboreal Man, New York, Chap. XXXI, p. 196

20. Keith, A., Ancient Types of Man, New York, I9I I

21. Haddon, A. C., Wanderings of Peoples, Cambridge, I9I I

22. Haddon, A. C., Races of Men and their Distribution, New York, I9Io

23. Keane, A. H., Ethnology, Cambridge, I901

24. Osborn, H. F., Men of the Old Stone Age, New York, I9I5

25. Sollas, W. J., Ancient Hunters, 2d Ed., London, I9I5

26. Elliott, G. F. S., Prehistoric Man and His Story, London, I9I5

27. Herter, C. A., Biological Aspects of Human Problems, New York, I9I I

28. Heineman, T. R., Psychic and Economic Results of Man's Physical Uprightness, Pasadena, Calif., 1906

29. Bagehot, W., Physics and Politics, New York, I873

30. Drummond, H., Ascent of Man, New York, I894

3I. Westermarck, E. A., History of Human Marriage, London, I90I

CHAPTER V. THE DAWN OF CIVILIZATION.

A. RACES

40. Ripley, W. L., Races of Europe, New York, I899

4I. Sergi, G., The Mediterranean Race, London, I90I

42. Klassen, K., Die Völker Europas zur jungeren Steiñeit, Stuttgart, I9I2, Bibliography

43. Deniker, J., The Races of Man, New York, I900, cf. 23 
B. Stone monuments. See $U$.

48. Peet, T. E., Rude Stone Monuments, New York, I9I2

49. Avebury Lord (Sir John Lubbock) Prchistoric Times, New York, I9I 3

50. Windle, B. C. A., Remains of Prehistoric Age in England, London, 1904

51. Cartailhae, E., La France Prehistorique, Paris, 1889

\section{GENERAL}

55. Tyler, J. M., The New Stone Age in Northern Europe, New York, I92 I, Bibliography

56. Mason, O. T., Woman's Share in Primitive Culture. New York, I907, Chap. II

57. Hoernes, M., Natur A. und Urgeschichte des Menschen, Vienna, I899, Vol. I, p. 535-59I

58. Hehn, V., Kulturpflanzen und Hausthicre, Berlin, I9I I

59. Hartley, C. G. (Mrs. W. M. Gallichan), The Position of Woman in Primitive Socicty, London, I9I4

6o. Ellis, H., Man and Woman, London, 4th Ed., I9I7

6г. Morgan J. de, Premicres Civilizations, Paris, 1909)

62. Sumner, Folkways, New Haven

63. Harrison, J. E., Ancicnt Art and Ritual, New York, I9I3

64. Harrison, J. E., Themis, Cambridge, I9I2

65. Harrison, J. E., Prolegomena to Greck Religion, Cambridge, I903

66. Murray, G., Four Stages of Greck Religion, New York, 1912

67. Tylor, E. B., Primitive Culture, 4th Ed., New York, 1903

68. Tylor, E. B., Anthropology, New York, 1916

69. Montgomery, J. E. (Editor), Religions of the Past and Present, Philadelphia, I9I8, Bibliography' 
70. Farnell, L. R., Greece and Babylon, Edinburg, I9I I, Chapter $\mathrm{V}$

7I. Frazer, J. G., The Golden Bough, 3rd Ed., London, I9I4, Bibliography

CHAPTER VI. RISE OF PERSONALITY.

74. Aryans, See 55. Bibliography

75. Schrader, O., Die Indogermanen, Leipsic, I9I I

76. Feist, S., Kultur, Ansbreitung und Herkunft der Indogermanen, Berlin, I9I 3

77. Feist, S., Europa im Lichte der Vorgeschichte, Berlin, I9IO

78. Hirt, H., Die Indogermanen, 2 vols., Strassburg, 19051907

79. Reinach, S., Origine des Aryens, Paris, I892

80. Holmes, T. R., Ancient Britain, Oxford, I907, Chapter III and pp. 424-455

8I. Myres, J. L.. Daum of History, New York, I9I I

82. Demolins, E., Les Français d'Aujourdhui, Paris, I898

83. Demolins, E., Les Grandes Routes des Peuples, Paris, I90I

84. Henley, W. E., Book of Verses, New York, I89I

90. Huxley, J. S., The Individual in the Animal Kingdom, Cambridge, I9I2

9I. Ritter, W. E., The Unity of the Organism, Boston, I9I9

92. Child, C. M., Individuality in Organisms, Chicago, I9I 5

93. Driesch, H., (Trans. Ogden, C. H.) History of the Theory of Vitalism, London, I9I4 
94 Jenkinson, J. W., Experimental Embryology, Oxford, I909, Chap. V

B. NATURE

95. Shaler, N. S., Interpretation of Nature, Boston, 1893

96. Wallace, A. R., The World of Life, New York, I9I I

97. Wallace, A. R., Contributions to the Theory of Natural Selection, London, $187 \mathrm{I}$

98. Wallace, A. R., Social Environment and Moral Progress, New York, I9I3

99. Huxley, T. H., Evolution and Ethics, New York, 1905

I00. Thomson, J. A., The Bible of Nature, New York, I908, pp. $210-235$

IOI. Sperry, W. L., The Discipline's of Liberty, New Haven, I92I, p. 67

102. Nietzsche, F., Complete works, (O. Levy Ed.) $2 \mathrm{~d}$ Ed. New York, I9Io, Vol. XI, Thus Spake Zarathustra, pp. I66, I7 I I03. Journal of Morphology, Vol. VIII, pp. 649. 607

I04. Wilson, E. B., The Cell, New York, 2d Ed., Igo4

CHAPTER IX. MAN AND ENVIRONMENT.

See A. C. H. L. M. Q.

9 I, $96-98$

I Io. Romanes, G. J., Darwin and After Darwin, 4th Ed., Chicago, I9IO

I I I. Baldwin, J. M., Development and Evolution, New York, 1902

I12. Lock, R. H., Recent Progress in the Study of Variation, Heredity and Evolution, New York, I9I6

I13. Henderson, L. J., The Fitness of the Enironment, New York, 1913

I 14. Art, Adaptation, in Hastings, J. A. Encyclopedia of Religion and Ethics 
I 5. Conklin, E. G., Heredity and Environment in the Development of Men, Princeton, I9I5

I16. Herbert S., First Principles of Evolution, London, I9I3

CHAPTER X. SURVIVAL OF THE FITTEST.

Sec A. C. H. J. L. M.

N.P. 97, I Iо, under Natural Selection

I25. Wundt, M., Griechische Weltanschaung, Leipsic, I9Io

126. James, W., Will to Belicve

I27. James, W., Psychology, New York, I893, p. IOI

Chapter Xi. PERfect health. See I26, I27

I35. Tyler, J. M., Growth and Education, Boston, I907, Bibliography

136. Burk, F. L. and C. F., The Study of the Kindergarten Problem, San Francisco, I 899

137. Burk, F. L., The Kindergarten Child, Physically, N. E. A. I899, 570, cf. I05 I

I38. Hall, G. S., Contents of Children's Minds on Entering School, Pedagog, Sem. I891, Vol. I39

I39. Hall, G. S., Adolcsconce, New York, I904

I40. Hall, G. S., Youth, New York, I906

I4I. Gulick, L. H., The Efficient Life, New York, I907

142. James, W., Talks to Teachers, New York, 1905 
INDEX 



\section{INDEX}

Adolescence, 128

Adversity, 112

Agriculture, Rise of, 55, 65

Aladdin's Lamp, 7, 123

Alciope, 17

Amoeba, 4

Ammonites, 23

Amphibia, 32, 73

Annelids, 15, 72

Apes, 38, 40, 76

Arboreal Life, Results of, 38

Archenteron, 10

Arthropoda, 19, 24, 72

Aryans, 65, 125

Athletes, 120, 122

Baby, Life of, 125

Bacteria, 2

Bergson, (Quoted), 7, 83, 84, 118

Birds, 35, 74, 109

Bone, 28, 84

Brain, 25, 28, 39, 75, 78

Bronze Age, 67

Carnivora, (Cats), 47, 110

Cartilage, 28

Cells, 4, 11

Cellulose, 9

Cenozoic, 37

Celts, 67

Cephalopods, 22, 108

Chellean Period, 49

Chlorophyl, 9

Chordata, 27, 107

Chromatin, 4

Circulation, 14

Clam, 19

Coelenterates, 10, 71

Coelom, 16

Complexity of Man, 91
Conformity to Environment, 97

Conversion, 130

Conscience, Tribal, 56

Cooperation, Growth of, 58

Cretaceous Period, 36, 41

Cripples, Reversed, 92-3, 132

Cro-Magnon Race, 51

Ctenophores, 14

Cuttle-fish, 22, 107

Custom, Cake of 57,58

Dead, Care of, 50,54

Devonian Period, 31

Dinosaurs, 34

Direction in Evolution, 83

Discovery, 100

Dog-fish, 29

Dolmens, 54

Dominance and Fitness, 111, 116, 134

Dominant Functions, 77

Drummond, 47

Dubois, 43

Ear, 17

Echidna, 36

Ectoderm, 10

Education, natural, 81, 112 artificial, 103

Eggs, Size of, 33, 35

Ellis, 48

Ends and Values, 124

Entoderm, 10

Environment, 97, 101, 131 artificial, 102

Enzymes, 3

Evolution; and Revolution, 78; Logic

of, 71 ; Direction in, 83

Eye, 17, 25, 100

Family, 47, 49 
Fishes; 27, Ganoids, 29-31, Sharks, Mammals, 36, 74 28, 108

Fittest, Survival of, 111, 116, 134

Flagellata, 7

Folk-ways, 58

Games, 126, 128

Ganoids, 29-31

Gasteropods, 21

Glacial Period, 46

Gladiatorial Theory, 110

Goddess, Cult of, 63, 66

Greek Civilization, 67

Grosgartach, 53

Gymnasts, 120, 132

Habits, 58, 122

Hairs, 37

Hall, 128

Hamitic Migrations, 45

Hand, 38, 39

Health, 119

Heine, (Quoted), 92

Henley, (Quoted), 69

Heredity, 95

Heroes, Age of, 68

Hormones, 84

Hunting, (Collecting), 54

Huxley, (Quoted), 7, 70, 81, 85, 88, 95,117

Insects, 24

Intelligence, 75

Interests, 124

Iranian Plateau, 42, 44

Iron Age, 68

James, (Quoted), 113, 116, 133

Java, 43

Johnson, (Quoted), 131

Kindergarten, 126

Lake Dwellings, 53

Land-Life, Rise of, 31

Lull, (Quoted), 33, 41

Marsupials, 37, 47

Mass vs. Surface, 6

Mesozoic Era, 1, 36, 109

Metamorphosis, 26

Migrations; of Apes, 42, of Negroes 44, of Hamites and Semites, 45

Mind, 122

Mollusca, 19, 72, 107

Momentum of Evolution, 114

Murray, on Primitive Religion, 60

Muscle, 14, 16, 20, 39, 78

Mysteries, 61

Nägeli, 86

Naturai Selection, 86

Nature, 88, 94, 112, 116, 118, 131, 135

Neanderthal Man, 46, 49

Needs, 102, 112

Negritos, 44

Negros, 45

Neo-Darwinians, 86

Neo-Lamarckians, 87

Neolithic Period, 53, 64

Nietzsche, (Quoted), 92

Nitrogen, Fixation of, 3

Nucleus, 4

Olympic Religion, 62

Osborn (Quoted), 3, 44, 76

Otolith Vesicles, 17

Over-Adaptation, 98, 103, 132

Palaeolithic Period, 51

Palaeozoic Era, 1, 107

Parenchym, 14

Periods, Geologic, 1

Perivisceral Cavity, 16

Personality, 69, 83

Pigmies, 44

Pithecanthropus, 43

Plants, 8, 9

Plato, 115

Platyhelminthus, 13

Platypus, 36

Play, 126

Pleistocene, 46 
Plutarch, (Quoted), 63

Precocity, 110

Primates, 38, 41

Progress, 106, 114

Proportion, 120

Protoplasm, 2

Protophyta, 2

Protozoa, 2, 4

Psychozoic Time, 110

Pteropoda, 21

Relations to Surroundings, 99

Religion, 59, 62, 66

Reproduction, 10, 14, 33

Reptiles, 34, 74, 109

Reversed Cripples, 93, 132

Schuchert, (Quoted), 1

Semites, 45

Sense-organs, 14, 16, 25, 29, 100

Sequence of Functions, 71, 79

Sharks, 23, 28, 29, 108

Skeleton, 19, 23, 27, 28, 32

Social Life, 57

Socrates and Callicles, 114

Specialization, 132

Squids, 23, 107

Stages in Human Evolution, 77
Stimuli, 121

Struggle for existence, 79

Surroundings and Environment, 99, 105

Symmetry, 91, 120

Taboo, 59

Thomson, (Quoted), 117

Totem, 68

Tribal Conscience, 56

Tribes, 56

Ungulates, 47

Vacuoles, 4

Values, 124

Variation, 87

Vertebrates, 19, 23, 27, 73

Volvox, 7, 10

von Baer, (Quoted), 98

Weakest Part, 120

Weissman (Quoted), 97

Westermarck, (Quoted), 48

Whitman, 79, 85

Wilson, (Quoted), 85

Woman, Neolithic, 55

Wundt, (Quoted), 115 



\section{The Amberst}

In connection with the celebration of her one hundredth anniversary, Amherst College began the publication of a series of volumes, written by Amherst men, to be known as The Amherst Books. They deal simply and clearly with matters and problems of significance and are addressed primarily, not to the expert and specialist, but to the general intelligent public. The list of volumes published and in preparation follows.

\section{THE LIBERAL COLLEGE}

\section{By ALEXANDER MEIKLEJOHN}

PRESIDENT OF AMHERST COLLEGE

A frank and thorough discussion of the fundamental problems of college education and of the function which the college should fulfill in American life and thought. The topics discussed are arranged under four general headings: The Determining Purpose, The Participants in the Process, Discussions in Educational Theory and The Curriculum.

Price $\$ 2.50$, postage io cents

\section{THE LIFE INDEED \\ By JOHN FRANKLIN GENUNG}

LATE PROFESSOR OF BIBLICAL AND LITERARY INTERPRETATION IN AMHERST COLLEGE

The matured and genial philosophy of a much loved teacher who was widely recognized as a shrewd scholar in the fields of literature and religion. All the characteristic qualities of mind, revealed hitherto in his rhetoric, in his studies of Hebrew literature and in his interpretations of English poets, are here brought into play to build up a systematic design of the only sort of life to him worth living, a life founded on the Bible, his "great textbook of life."

Price $\$ 3.00$, postage 10 conls

MARSHALL JONES COMPANY, PUBLISHERS

2 I2 SUmmer Street BOSTON, MASS. 


\section{The Amberst}

\section{ESSAYS IN BIBLICAL INTERPRETATION}

\section{By HENRY PRESERVED SMITH}

DAVENPORT PROFESSOR OF HEBREW AND THE COGNATE LANGUAGES IN UNION THEOLOGICAL SEMINARY

These essays by a well-known scholar whose "Old Testament History" is a standard work, treat, in chronological order, the various ways in which men have attempted to explain the meaning of the Old Testament.

Price $\$ 2.50$, postage 10 cents

\section{PARTIES AND PARTY LEADERS \\ By ANSON DANIEL MORSE}

LATE PROFESSOR OF HISTORY IN AMHERST COLLEGE

With an Introduction by Dwight Whitney MoRrow

A collection of the best political essays of a singularly clearminded and unbiassed analyst of American institutions. Hitherto scattered in various periodicals, these papers are now brought together into a volume which covers, in a notably clear and impartial way, the history of our politics down to I9I4.

Price $\$ 2.50$, postage Io cents

\section{GERMANY IN TRAVAIL \\ By OTTO MANTHEY-ZORN}

PROFESSOR OF GERMAN IN AMHERST COLLEGE

Recent observations of the spiritual conditions in Germany by a student of literature.

Price $\$ 2.00$, postage Io cents

MARSHALL JONES COMPANY, PUBLISHERS 212 SUMMER STREET BOSTON, MASS. 



